\title{
Geochemistry and Stratigraphic Relations of Middle Proterozoic Rocks of the New Jersey Highlands
}

U.S. GEOLOGICAL SURVEY PROFESSIONAL PAPER 1565-C 


\section{Availability of Publications of the U.S. Geological Survey}

Order U.S. Geological Survey (USGS) publications by calling the toll-free telephone number 1-888-ASK-USGS or contacting the offices listed below. Detailed ordering instructions, along with prices of the last offerings, are given in the current-year issues of the catalog "New Publications of the U.S. Geological Survey.”

\section{Books, Maps, and Other Publications}

\section{By Mail}

Books, maps, and other publications are available by mail from-

USGS Information Services

Box 25286, Federal Center

Denver, CO 80225

Publications include Professional Papers, Bulletins, WaterSupply Papers, Techniques of Water-Resources Investigations, Circulars, Fact Sheets, publications of general interest, single copies of permanent USGS catalogs, and topographic and thematic maps.

\section{Over the Counter}

Books, maps, and other publications of the U.S. Geological Survey are available over the counter at the following USGS Earth Science Information Centers (ESIC's), all of which are authorized agents of the Superintendent of Documents:

- Anchorage, Alaska-Rm. 101, 4230 University Dr.

- Denver, Colorado-Bldg. 810, Federal Center

- Menlo Park, California-Rm. 3128, Bldg. 3, 345 Middlefield Rd.

- Reston, Virginia-Rm. 1C402, USGS National Center, 12201 Sunrise Valley Dr.

- Salt Lake City, Utah-2222 West, 2300 South (books and maps available for inspection only)

- Spokane, Washington-Rm. 135, U.S. Post Office

Building, 904 West Riverside Ave.

- Washington, D.C.-Rm. 2650, Main Interior Bldg., 18th and C Sts., NW.

Maps only may be purchased over the counter at the following USGS office:

- Rolla, Missouri-1400 Independence Rd.

\section{Electronically}

Some USGS publications, including the catalog "New Publications of the U.S. Geological Survey," are also available electronically on the USGS's World Wide Web home page at http://www.usgs.gov

\section{Preliminary Determination of Epicenters}

Subscriptions to the periodical "Preliminary Determination of Epicenters" can be obtained only from the Superintendent of
Documents. Check or money order must be payable to the Superintendent of Documents. Order by mail from-

Superintendent of Documents

Government Printing Office

Washington, DC 20402

\section{Information Periodicals}

Many Information Periodicals products are available through the systems or formats listed below:

\section{Printed Products}

Printed copies of the Minerals Yearbook and the Mineral Commodity Summaries can be ordered from the Superintendent of Documents, Government Printing Office (address above). Printed copies of Metal Industry Indicators and Mineral Industry Surveys can be ordered from the Center for Disease Control and Prevention, National Institute for Occupational Safety and Health, Pittsburgh Research Center, P.O. Box 18070, Pittsburgh, PA 15236-0070.

\section{Mines FaxBack: Return fax service}

1. Use the touch-tone handset attached to your fax machine's telephone jack. (ISDN [digital] telephones cannot be used with fax machines.)

2. Dial (703) 648-4999.

3. Listen to the menu options and punch in the number of your selection, using the touch-tone telephone.

4. After completing your selection, press the start button on your fax machine.

\section{CD-ROM}

A disc containing chapters of the Minerals Yearbook (199395), the Mineral Commodity Summaries (1995-97), a statistical compendium (1970-90), and other publications is updated three times a year and sold by the Superintendent of Documents, Government Printing Office (address above).

\section{World Wide Web}

Minerals information is available electronically at http://minerals.er.usgs.gov/minerals/

\section{Subscription to the catalog "New Publications of the U.S. Geological Survey"}

Those wishing to be placed on a free subscription list for the catalog "New Publications of the U.S. Geological Survey" should write to-

U.S. Geological Survey

903 National Center

Reston, VA 20192 


\section{Geochemistry and Stratigraphic Relations of Middle Proterozoic Rocks of the New J ersey Highlands}

By Richard A. Volkert and Avery Ala Drake, J r.

\section{U.S. GEOLOGICAL SURVEY PROFESSIONAL PAPER 1565- C}

Prepared in cooperation with the

New J ersey Geological Survey

New J ersey Highlands M iddle Proterozoic rocks include

sodic basement rocks of the Losee M etamorphic Suite and an

unconformably overlying metasedimentary sequence

intruded by synkinematic granitoids $(\sim 1,090 \mathrm{M} \mathrm{a})$ and

postkinematic granite $(1,020 \mathrm{Ma})$ 


\title{
U.S. DEPARTM ENT OF THE INTERIOR BRUCE BABBITT, Secretary
}

\author{
U.S. GEOLOGICAL SURVEY \\ CHARLES G. GROAT, Director
}

UNITED STATES GOVERNM ENT PRINTING OFFICE, WASHIN GTON : 1999

Published in the Eastern Region, Reston, Va.

M anuscript approved for publication October 27, 1998.

Any use of trade, product, or firm names in this publication is for descriptive purposes only and does not imply endorsement by the U.S. Government.

For sale by

U.S. Geological Survey

Information Services

Box 25286, Federal Center

Denver, CO 80225

\section{Library of Congress Cataloging in Publication Data}

Volkert, Richard A.

Geochemistry and stratigraphic relations of Middle Proterozoic rocks of the New J ersey Highlands / by Richard A. Volkert and Avery Ala Drake, J r.

p. cm.- (Geologic studies in New J ersey and eastern Pennsylvania ; C) (U.S. Geological Survey professional paper ; 1565)

"Prepared in cooperation with the New J ersey Geological Survey."

Includes bibliographical references.

Supt. of Docs. no.: I 19. $16: 1565-C$

1. Geology, Stratigraphic- Proterozoic. 2. Geology- New Jersey- New Jersey Highlands. 3. Geochemistry- New J ersey- New J ersey Highlands. I. Drake, Avery Ala, 1927- . II. New J ersey Geological Survey. III. Title. IV. Series. V. Series: U.S. Geological Survey professional paper ; 1565.

QE141.G46 1995 vol. C

[QE653.5]

$557.49 s-d c 21$

[551.7' 15' 09749] 


\section{CONTENTS}

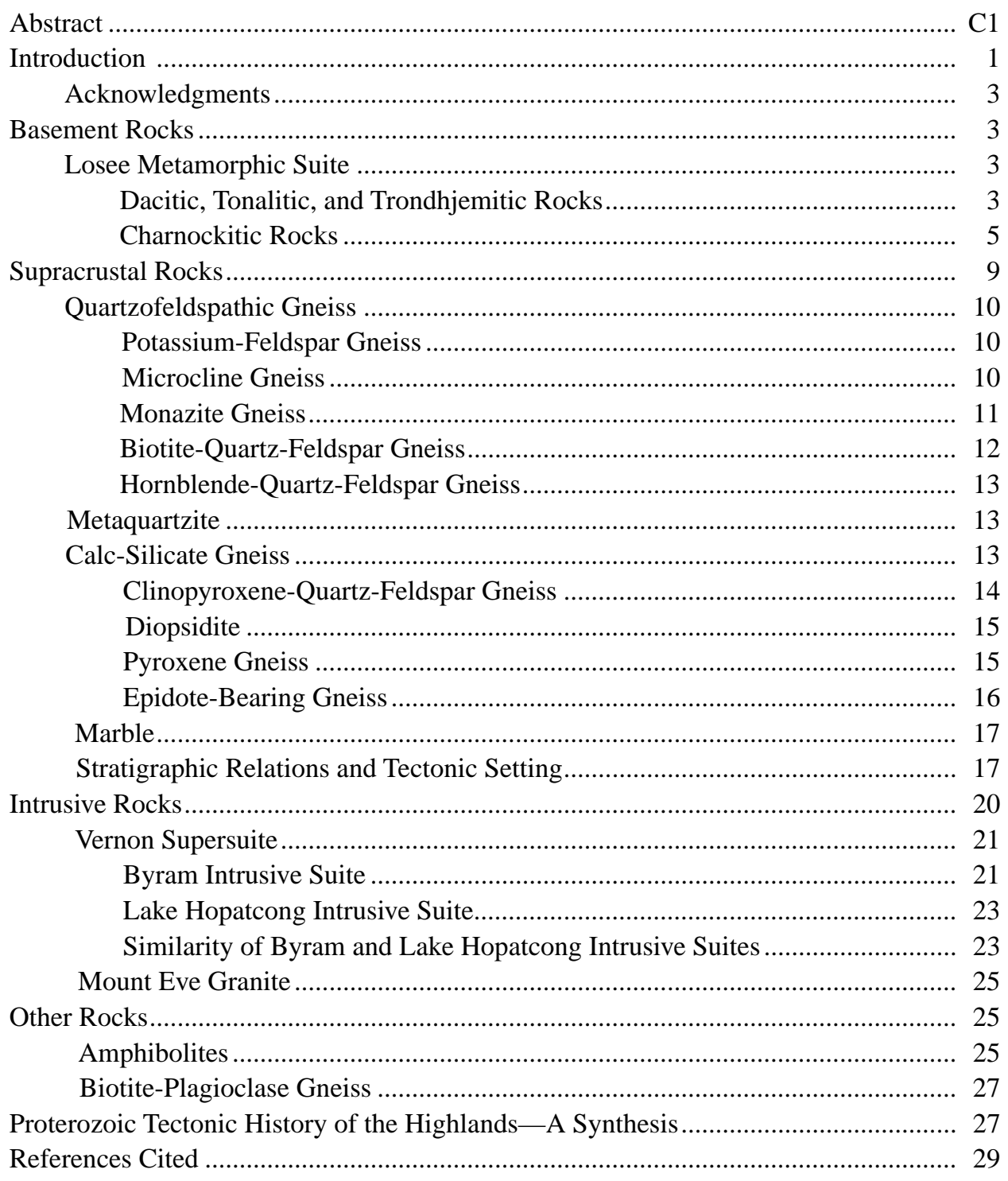

\section{FIGURES}

1. Generalized geologic map showing distribution of Middle Proterozoic, Paleozoic, and Mesozoic rocks in northern New Jersey

2. Geologic map showing distribution of Losee Metamorphic Suite rocks in the New Jersey Highlands

3. Photograph showing angular unconformity between feldspathic metaquartzite and layered charnockitic gneiss and amphibolite, Wanaque quadrangle, New Jersey 
4-10. Plots of data for rocks of the Losee Metamorphic Suite in the New Jersey Highlands:

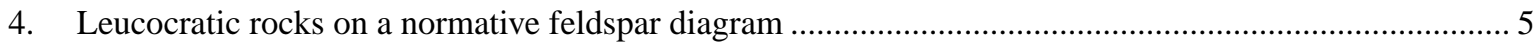

5. Layered charnockitic rocks on a total alkali-silica diagram ............................................................... 6

6. Layered charnockitic rocks, massive charnockitic rocks, and leucocratic rocks on a normative Qtz-Or-(Ab+An) diagram

7. Layered charnockitic rocks, massive charnockitic rocks, and leucocratic rocks on an AFM diagram....... 7

8. Layered charnockitic rocks, massive charnockitic rocks, and leucocratic rocks on a diagram of

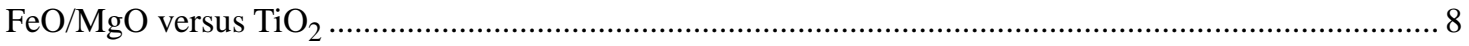

9. Layered charnockitic rocks, massive charnockitic rocks, and leucocratic rocks on a diagram of

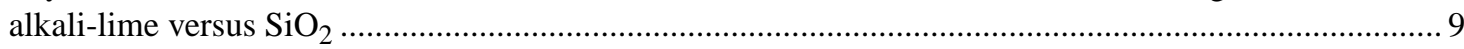

10. Layered charnockitic rocks, massive charnockitic rocks, and leucocratic rocks on a CaO- $-\mathrm{Al}_{2} \mathrm{O}_{3}$ $\left(\mathrm{FeO} \mathrm{Total}_{\mathrm{TgO}}+\mathrm{Mg}\right)$ diagram ......

11. Geologic map showing distribution of rocks of quartzofeldspathic composition in the New Jersey Highlands.

12. Plot of $\mathrm{Si} /(\mathrm{Si}+\mathrm{Al})$ versus $(\mathrm{Na}+\mathrm{Ca}) /(\mathrm{Na}+\mathrm{Ca}+\mathrm{K})$ for metasedimentary rock types in the New Jersey Highlands

13. Geologic map showing distribution of rocks of calc-silicate composition in the New Jersey Highlands

14. Photograph showing thin diopsidite lens within clinopyroxene-quartz-feldspar gneiss from the Stanhope quadrangle, New Jersey ......

15. Plot of $\mathrm{Al}_{2} \mathrm{O}_{3} /\left(\mathrm{CaO}+\mathrm{Na}_{2} \mathrm{O}\right)$ versus $\mathrm{Fe}_{2} \mathrm{O}_{3 \text { Total }}+\mathrm{MgO}$ for metasedimentary rock types in the New Jersey Highlands .16

16. Geologic map showing distribution of marble in the New Jersey Highlands.................................................. 18

17, 18. Plots of data for metasedimentary rock types in the New Jersey Highlands:

17. $\mathrm{Na}_{2} \mathrm{O}-\left(\mathrm{Fe}_{2} \mathrm{O}_{3 \text { Total }}+\mathrm{MgO}\right)-\mathrm{K}_{2} \mathrm{O}$ diagram.

18. $\log \mathrm{K}_{2} \mathrm{O} / \mathrm{Na}_{2} \mathrm{O}$ versus $\mathrm{SiO}_{2}$ diagram

19. Geologic map showing distribution of intrusive rocks in the New Jersey Highlands ......

20. Generalized geologic map of type area of the Vernon Supersuite in the Hamburg (New Jersey) and Wawayanda (New Jersey-New York) quadrangles....

21-24. Plots of data for granitic rocks in the New Jersey Highlands:

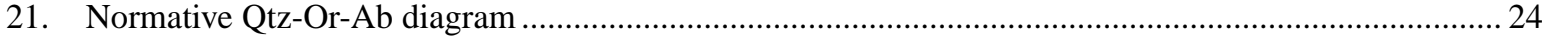

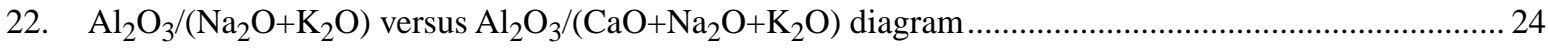

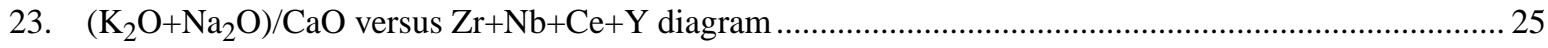

24. $\left(\mathrm{Al}_{2} \mathrm{O}_{3}+\mathrm{CaO}\right) /\left(\mathrm{FeO}_{\mathrm{Total}}+\mathrm{Na}_{2} \mathrm{O}+\mathrm{K}_{2} \mathrm{O}\right)$ versus $100\left(\left[\mathrm{MgO}+\mathrm{FeO}_{\mathrm{Total}}+\mathrm{TiO}_{2}\right] / \mathrm{SiO}_{2}\right)$ diagram................... 25

25. Plot of $\log \mathrm{TiO}_{2}$ versus $\mathrm{Mg}^{\prime}$ for amphibolites in the New Jersey Highlands ................................................. 26

26. Schematic diagram showing inferred stratigraphic relations of Middle and Late Proterozoic rocks in the New Jersey Highlands .28

\section{TABLES}

[Tables 1-18 follow References Cited]

1-9. Major-oxide and trace-element concentrations and CIPW norms of rocks of the New Jersey Highlands:

1. Leucocratic rocks of the Losee Metamorphic Suite....

2. Layered charnockitic rocks ( $\mathrm{Yh}$ ) of the Losee Metamorphic Suite.

3. Massive charnockitic rocks (Yd) of the Losee Metamorphic Suite

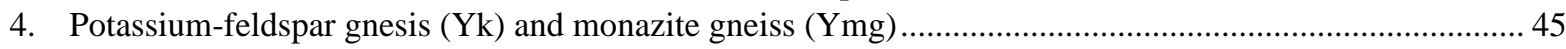

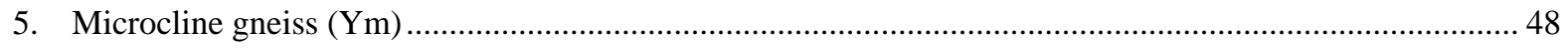

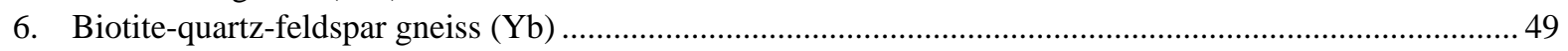

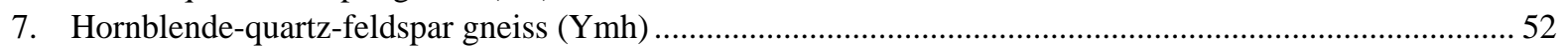

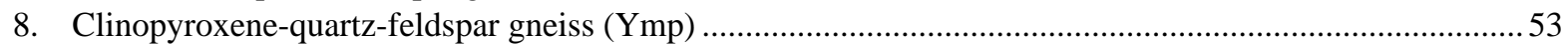


9. Diopsidite.

10. Major-oxide concentrations in clinopyroxenes and plagioclase in sample 242 of pyroxene gneiss (Yp) from the New Jersey Highlands ....

11. Major-oxide and trace-element concentrations and CIPW norms of pyroxene gneiss (Yp), New Jersey Highlands

12. Major-oxide ratios for the three geochemical types of pyroxene gneiss (Yp),

New Jersey Highlands.

13-15. Major-oxide and trace-element concentrations and CIPW norms of rocks of the New Jersey Highlands:

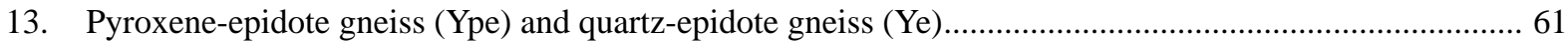

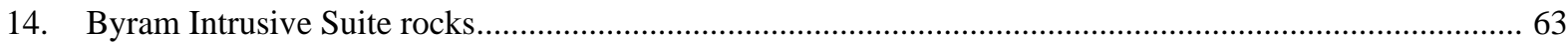

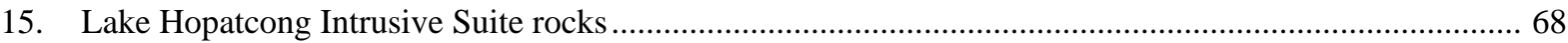

16. Major-oxide concentrations and CIPW norms of the Mount Eve Granite (Ygm),

New Jersey Highlands.

17, 18. Major-oxide and trace-element concentrations and CIPW norms of rocks of the New Jersey Highlands:

17. Amphibolite (Ya)

18. Biotite-plagioclase gneiss (Ybp)

\section{METRIC CONVERSION FACTORS}

\begin{tabular}{rcl}
\hline Multiply & By & To obtain \\
\hline inch (in.) & 25.4 & millimeter \\
foot (ft) & 0.3048 & meter \\
mile $(\mathrm{mi})$ & 1.609 & kilometer \\
square mile $\left(\mathrm{mi}^{2}\right)$ & 2.590 & square kilometer \\
\hline
\end{tabular}

To convert degrees Celsius $\left({ }^{\circ} \mathrm{C}\right)$ to degrees Fahrenheit $\left({ }^{\circ} \mathrm{F}\right)$, use the following:

$$
{ }^{\circ} \mathrm{F}=\left(1.8 \times{ }^{\circ} \mathrm{C}\right)+32
$$




\title{
GEOLOGIC STUDIES IN NEW JERSEY AND EASTERN PENNSYLVANIA
}

\section{Geochemistry and Stratigraphic Relations of Middle Proterozoic Rocks of the New Jersey Highlands}

\author{
By Richard A. Volkert ${ }^{1}$ and Avery Ala Drake, $\mathrm{Jr}^{2}$
}

\begin{abstract}
The New Jersey Highlands are underlain principally by Middle Proterozoic orthogneiss, paragneiss, and marble that were metamorphosed to upper amphibolite to hornblendegranulite facies and were intruded by granitoid rocks. The oldest rocks are dacitic, tonalitic, and trondhjemitic gneiss and granite of calc-alkaline affinity and metabasalt of the Losee Metamorphic Suite. They are associated spatially with quartz-rich and quartz-poor charnockitic rocks. Field relationships and geochemical data support a cogenetic interpretation for the dacitic, tonalitic, and trondhjemitic rocks and the charnockitic rocks. They are herein all included in the Losee Metamorphic Suite.

The rocks of the Losee Metamorphic Suite form a basement assemblage that is unconformably overlain by a layered sequence of supracrustal rocks that consist of quartzofeldspathic gneiss of arkosic and (or) graywacke composition, metaquartzite, calc-silicate gneiss, and marble. Quartzofeldspathic gneiss and calc-silicate gneiss are ubiquitous, but marble occurs mainly in the western Highlands. Metaquartzite occurs as thin lenses and layers throughout the Highlands and provides an excellent marker. Amphibolite formed from different protoliths is widespread and is found in virtually all Middle Proterozoic rocks.

Widespread synorogenic granitoids include the hornblende- and biotite-bearing rocks of the Byram Intrusive Suite, dated at between $1,116 \pm 41 \mathrm{Ma}$ and $1,088 \pm 41 \mathrm{Ma}$, and the clinopyroxene-bearing rocks of the Lake Hopatcong Intrusive Suite, dated at $1,095 \pm 9$ Ma. Both have similar major- and trace-element abundances and are interpreted as having fractionated from the same magma. They are included as suites in the Vernon Supersuite. The postorogenic Mount Eve Granite has been dated at 1,020 \pm 4 Ma and is confined to the extreme northern Highlands.

Middle Proterozoic rocks are very locally unconformably overlain by weakly metamorphosed Late Proterozoic
\end{abstract}

\footnotetext{
${ }^{1}$ New Jersey Geological Survey, Trenton, NJ 08625.

${ }^{2}$ U.S. Geological Survey, Reston, VA 20192.
}

rocks of the Chestnut Hill Formation and are intruded by abundant diabase dikes of Late Proterozoic age. The Proterozoic rocks are unconformably overlain by the Lower Cambrian Hardyston Quartzite.

\section{INTRODUCTION}

The geology of the Middle Proterozoic crystalline rocks of the New Jersey Highlands has been a subject of study for over a century. The pioneering work of early geologists resulted in a subdivision of the crystalline rocks into the Byram Granite Gneiss, Pochuck Gneiss, Losee Pond Granite, and Franklin White Limestone. This generic breakdown was refined by geologists of the New Jersey Zinc Company (for example, Hague and others, 1956) and the U.S. Geological Survey (for example, Sims and Leonard, 1952; Hotz, 1953; Sims, 1958; Drake, 1969) into a more practical breakdown based on mineralogy. Detailed geologic mapping of the Highlands by the New Jersey Geological Survey and the U.S. Geological Survey since 1984, undertaken for the new geologic map of New Jersey, has led to further lithologic refinement and a more complete understanding of the geologic and stratigraphic relations of the various Middle Proterozoic rocks. Currently, more than 30 different units are recognized, and most are shown on the new State geologic map (Drake and others, 1996). These units were distinguished on the basis of distinctive mineralogy and (or) geochemistry as revealed by the numerous analyses for major oxides and trace elements presented here. Unit designations from Drake and others (1996), such as Ylh, are used in this paper with modifications explained in the text.

It is beyond the scope of this paper to provide a complete historical perspective of all previous work in the Highlands. Our intent is to discuss the geochemistry, lithology, and stratigraphy of the various Middle Proterozoic units in the New Jersey Highlands mainly within the context of new information and interpretations developed from our recent study of these complex and interesting rocks.

Middle Proterozoic rocks of the upper amphibolite to hornblende-granulite facies underlie the New Jersey 
Highlands and the physically contiguous Hudson Highlands in New York State and the Durham and Reading Hills in Pennsylvania. These rocks constitute one of the largest of the numerous Middle Proterozoic (Grenvillian) massifs in the eastern United States that extend northeastward from Alabama to Vermont. These massifs are the exposed roots of the Laurentian Appalachian orogen and contain rocks older than $1 \mathrm{Ga}$.

The Highlands occupy slightly over 1,000 square miles in northern New Jersey (fig. 1). They are divided into two subequal parts by sedimentary rocks of Cambrian through Devonian age of the Green Pond Mountain region. The
Highlands are in fault contact on the southeast with sedimentary and igneous rocks of Mesozoic age of the Newark basin and locally with sedimentary rocks of Cambrian and Ordovician age. On the northwest, the Middle Proterozoic rocks are unconformably overlain by, or in fault contact with, sedimentary clastic and carbonate rocks of Cambrian and Ordovician age that were deposited on the Laurentian continental margin. A generalized version of these geologic relations is shown in figure 1.

Most of the geochemical analyses presented here were performed by XRAL Activation Services, Ann Arbor, Mich. Concentrations of major oxides, except $\mathrm{FeO}$, and trace

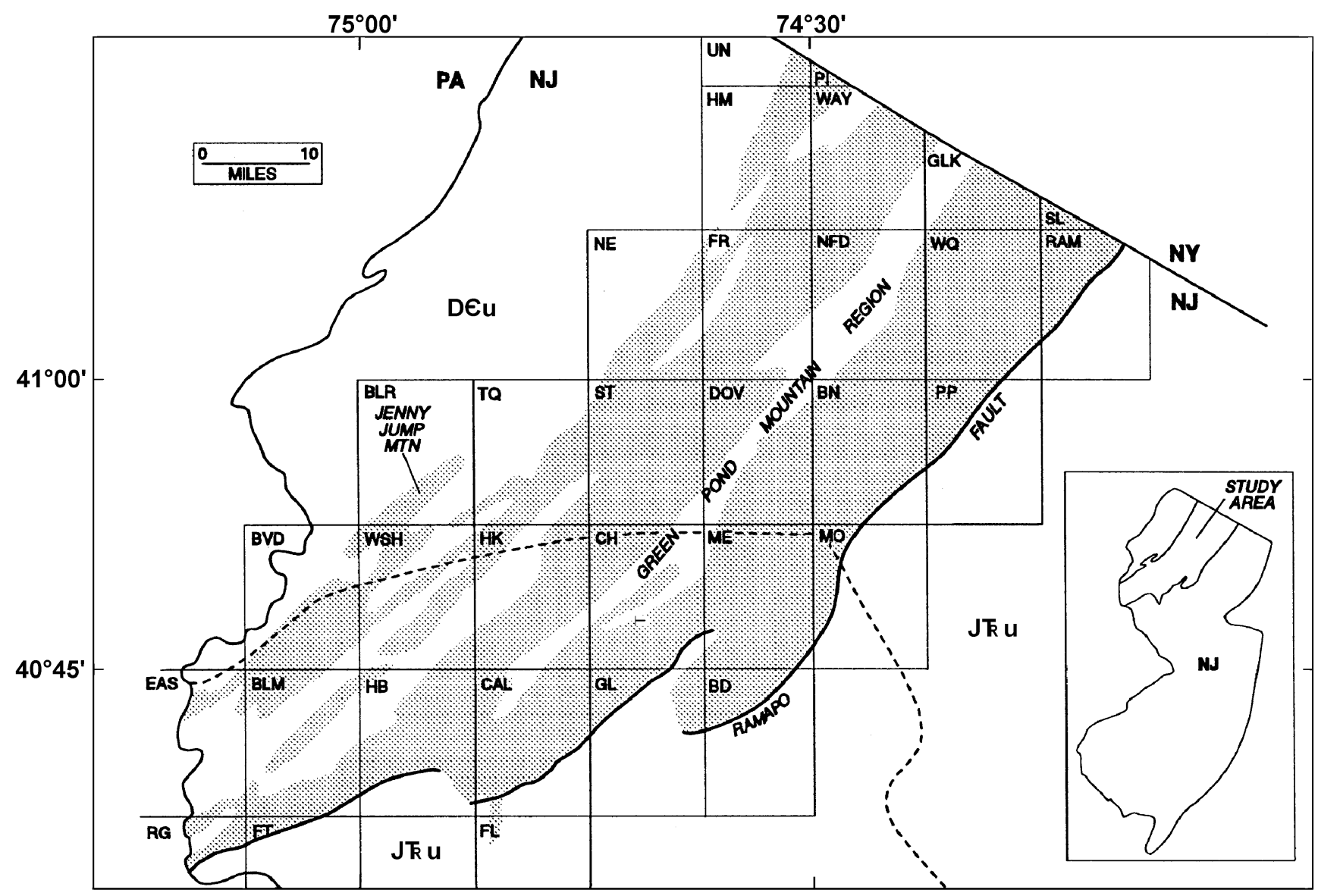

Abbreviations of 7.5-min quadrangles

$\begin{array}{llllllll}\text { UN } & \text { Unionville } & \text { NFD } & \text { Newfoundland } & \text { PP } & \text { Pompton Plains } & \text { BLM } & \text { Bloomsbury } \\ \text { PI } & \text { Pine Island } & \text { WQ } & \text { Wanaque } & \text { BVD } & \text { Belvidere } & \text { HB } & \text { High Bridge } \\ \text { HM } & \text { Hamburg } & \text { RAM } & \text { Ramsey } & \text { WSH } & \text { Washington } & \text { CAL } & \text { Califon } \\ \text { WAY } & \text { Wawayanda } & \text { BLR } & \text { Blairstown } & \text { HK } & \text { Hackettstown } & \text { GL } & \text { Gladstone } \\ \text { GLK } & \text { Greenwood Lake } & \text { TQ } & \text { Tranquility } & \text { CH } & \text { Chester } & \text { BD } & \text { Bernardsville } \\ \text { SL } & \text { Sloatsburg } & \text { ST } & \text { Stanhope } & \text { ME } & \text { Mendham } & \text { RG } & \text { Riegelsville } \\ \text { NE } & \text { Newton East } & \text { DOV } & \text { Dover } & \text { MO } & \text { Morristown } & \text { FT } & \text { Frenchtown } \\ \text { FR } & \text { Franklin } & \text { BN } & \text { Boonton } & \text { EAS } & \text { Easton } & \text { FL } & \text { Flemington }\end{array}$

Figure 1. Generalized geologic map of northern New Jersey showing Middle Proterozoic rocks of the Highlands (shaded), undivided Mesozoic rocks of the Newark Basin ( J $\mathbf{k} \mathbf{u}$ ), and undivided Paleozoic rocks of the Valley and Ridge (D€ $\mathbf{u}$ ). Dashed line marks limit of Wisconsinan terminal moraine. Small inset map locates study area shown in geologic map. 
elements were obtained by X-ray fluorescence spectrometry (XRF). FeO was determined by potentiometric titration (Jackson and others, 1987). Seventeen of the major- and trace-element analyses were done by the U.S. Geological Survey, Reston, Va., using XRF. These are samples in table 1, nos. F1, 3, and 994; table 2, no. 1106; table 3, nos. 746 and 108; table 4, no. B40; table 6, nos. G13 and D2; table 9, no. GL-N; table 14, nos. 999 and D1; table 15, nos. P37 and 76; and table 16, nos. PI-1, U-2, and NE-3.

\section{ACKNOWLEDGMENTS}

Most of the authors' recent mapping of rocks in the New Jersey Highlands and the acquisition of geochemical data on these rocks were done under the auspices of a cooperative geologic mapping program (COGEOMAP) between the New Jersey Geological Survey and the U.S. Geological Survey for the purpose of producing a new geologic map of New Jersey. We are grateful to D.B. Stewart and D.W. Rankin for helpful reviews. Additionally, Volkert thanks John Puffer for generously providing the microprobe data (table 10) obtained on a JEOL Superprobe at Rutgers University, David Harper for reviewing an earlier version of this paper, and Mary Ann Scott for helping with the geologic map figures.

\section{BASEMENT ROCKS}

The oldest rocks in the New Jersey Highlands are inferred to be an assemblage of leucocratic, plagioclase-rich metadacite and metatonalite gneiss and metatrondhjemite and associated metabasalt that are spatially associated with quartz-rich and quartz-poor charnockitic rocks. Collectively, they compose the Losee Metamorphic Suite. Rocks of the Losee Metamorphic Suite are widespread throughout the Highlands, where they appear to be unconformably overlain by a sequence of supracrustal rocks that consist of quartzofeldspathic gneiss, metaquartzite, calc-silicate gneiss, and marble. Dacitic, tonalitic, and trondhjemitic rocks are evenly distributed throughout the Highlands, whereas charnockitic rocks are most abundant in the eastern Highlands.

\section{LOSEE METAMORPHIC SUITE}

The name Losee was introduced by Wolff and Brooks (1898) for the light-colored rocks exposed at Losee Pond (currently known as Beaver Lake) in the Franklin quadrangle. They were named the Losee Pond Granite. Spencer and others (1908) changed the name to Losee Gneiss, the name shown on the old State geologic map of New Jersey (Lewis and Kümmel, 1912). Drake (1984) renamed these rocks the Losee Metamorphic Suite. The
Losee Metamorphic Suite is herein redefined to include previously unnamed charnockitic rocks of calc-alkaline affinity and associated amphibolite.

\section{DACITIC, TONALITIC, AND TRONDHJEMITIC ROCKS}

Dacitic, tonalitic, and trondhjemitic rocks (leucocratic rocks) of the Losee Metamorphic Suite occur throughout the Highlands in New Jersey but are most abundant in the Greenwood Lake, Franklin, Hamburg, Boonton, Califon, High Bridge, and Belvidere quadrangles (fig. 1). Their spatial distribution in the Highlands is shown in figure 2. These rocks have textural variations that range from well-layered gneiss and granofels to indistinctly foliated granite and pegmatite. The layered and granofels phases were mapped as biotite-quartz-oligoclase gneiss (Ylb) and quartz-oligoclase gneiss (Ylo) on the new State geologic map (Drake and others, 1996). Some phases mapped as Ylo contain appreciable amounts of hornblende and are described herein as hornblende-quartz-oligoclase gneiss (Ylh). The granitic phase was mapped as albite-oligoclase granite (Yla). Pegmatite occurs very locally and commonly was mapped with the granite.

Amphibolite (Ya) is commonly interlayered with all of the textural and compositional phases of the Losee. Although detailed chemistry on these amphibolites is lacking, they almost certainly represent metamorphosed basalt and (or) gabbro that was cogenetic with the leucocratic rocks of the Losee (Puffer and Volkert, 1991).

Dacitic, tonalitic, and trondhjemitic rocks of the Losee Metamorphic Suite are characteristically white weathering, are light greenish gray on fresh surfaces, and are medium to coarse grained. The essential minerals are quartz and plagioclase (oligoclase to andesine). Accessory minerals include biotite, hornblende, clinopyroxene, garnet, and magnetite.

Offield (1967) was among the first to advance the idea that Losee Metamorphic Suite rocks in the Hudson Highlands of New York were basement to the overlying metasedimentary rocks, and he suggested the possibility of an unconformity between them. Drake (1984) and Volkert and Drake (1990) proposed that the Losee is also basement to the other Middle Proterozoic rocks in New Jersey. Geologic mapping in the Wanaque quadrangle by Volkert (unpub. data) supports this interpretation, as an exposure of feldspathic metaquartzite, lithologically associated with potassium-feldspar gneiss, was found unconformably overlying amphibolite and charnockitic gneiss (fig. 3). The basal layers of metaquartzite contain clasts of the underlying amphibolite.

Samples of leucocratic rocks of the Losee plot in either the field of tonalite or the field of trondhjemite on a normative feldspar diagram (fig. 4). The geochemistry of the Losee is fairly distinctive, as these rocks typically 


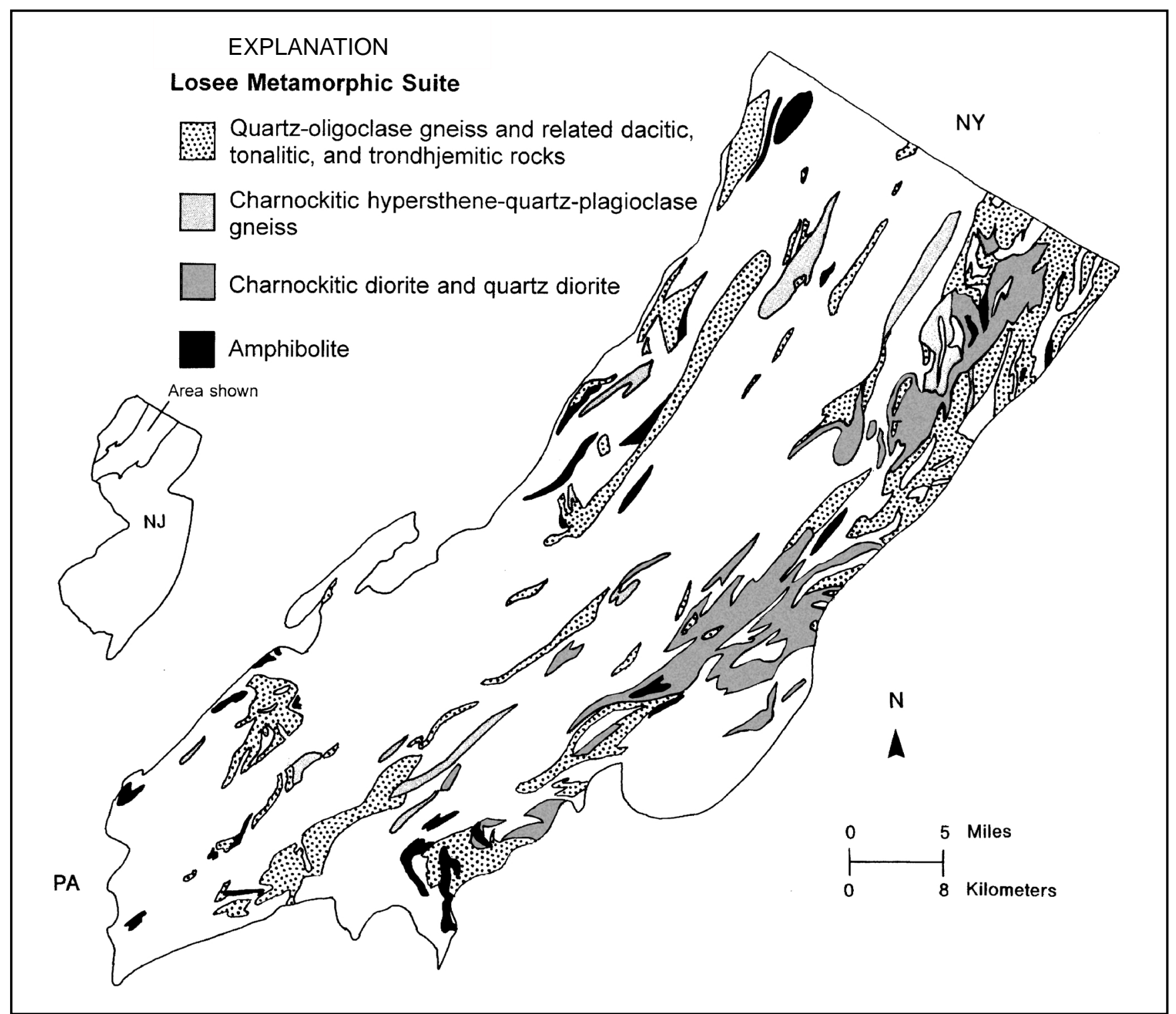

Figure 2. Distribution of leucocratic rocks (dacitic, tonalitic, and trondhjemitic rocks), charnockitic rocks, and amphibolite of the Losee Metamorphic Suite in the New Jersey Highlands. Modified from Drake and others (1996).

contain $>60$ weight percent $\mathrm{SiO}_{2}, 12$ to 19 weight percent $\mathrm{Al}_{2} \mathrm{O}_{3}$, and 3 to 7 weight percent $\mathrm{Na}_{2} \mathrm{O}$ (table 1; tables 1-18 follow References Cited). Drake (1969, 1984) interpreted the Losee to be a metamorphosed sequence of quartz keratophyre and basalt that possibly contained some intrusive trondhjemite and that originated in an oceanic environment. More recently, Puffer and Volkert (1991) proposed that rocks of the Losee Metamorphic Suite originated in a continental margin arc dominated by calcalkaline magmatism. The contents of $\mathrm{SiO}_{2}, \mathrm{Al}_{2} \mathrm{O}_{3}$, and $\mathrm{Na}_{2} \mathrm{O}$ and the $\mathrm{MgO} / \mathrm{FeO}$ ratios $(0.15-0.70)$ of Losee rocks are consistent with this interpretation. Therefore, the Losee likely represents a metamorphosed sequence of dacitic and tonalitic rocks and associated metabasalt (amphibolite).
Partial melting of basaltic source rock produced the metadacite and metatonalite of the Losee, whereas the more massive phases of the Losee were interpreted by Drake (1984) and Puffer and Volkert (1991), on the basis of textural relations and geochemistry, to be intrusions of trondhjemitic magma resulting from partial melting of metadacite and metatonalite of the Losee.

Isotopic dating of leucocratic Losee rocks is in progress. Similar rocks in Vermont have yielded ages of about 1,357 to 1,308 Ma (Aleinikoff and others, 1990), and others in the Adirondacks of New York have yielded ages of about 1,330 to 1,300 Ma (McLelland and Chiarenzelli, 1991). The age of the Losee in New Jersey probably is similar. 

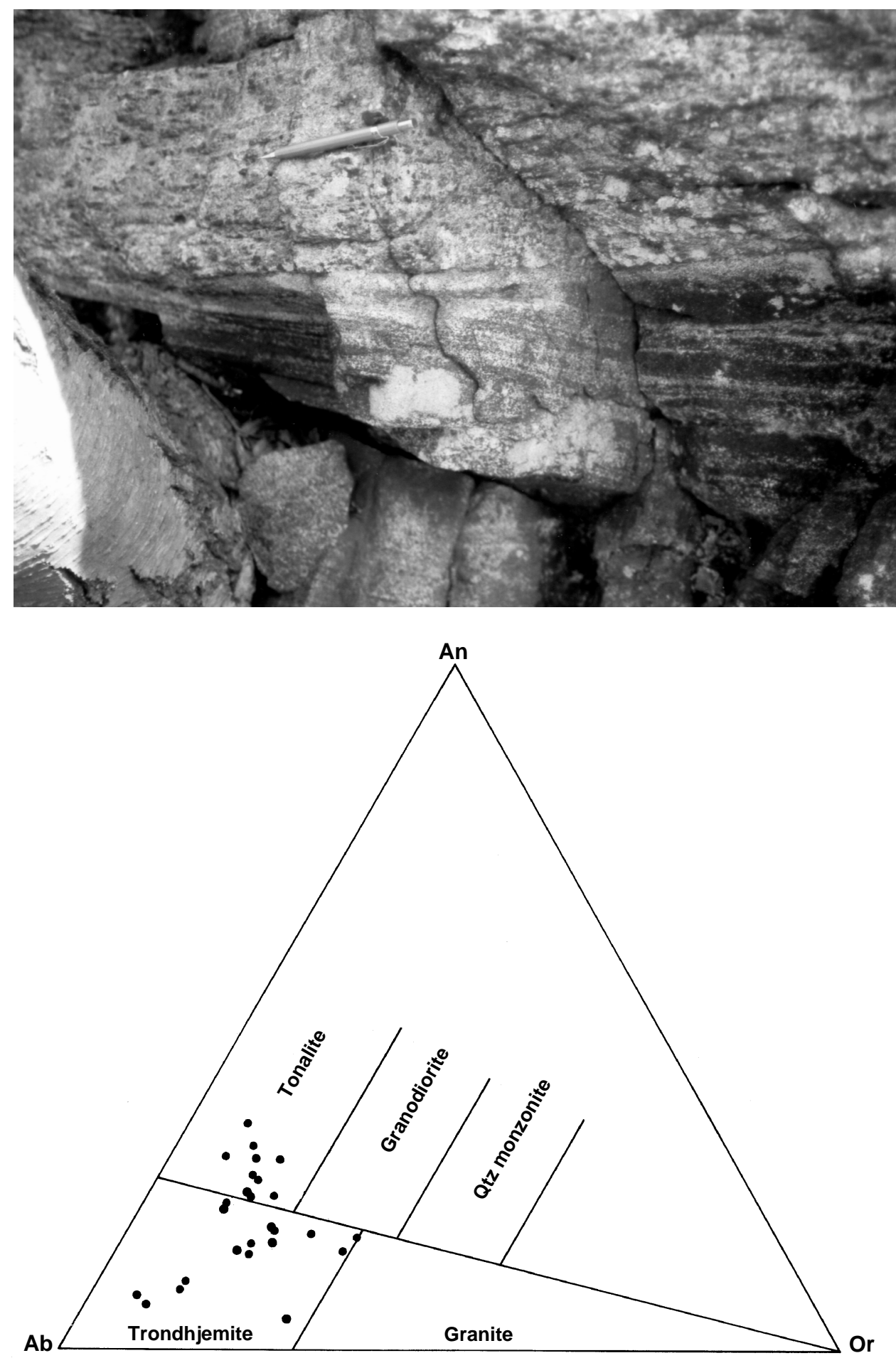

Figure 3. Angular unconformity between feldspathic metaquartzite (above) and layered charnockitic gneiss and amphibolite (below) from the Wanaque quadrangle, New Jersey. Pencil for scale is 5.5 in. long.
Figure 4. Normative feldspar diagram (O'Conner, 1965) of leucocratic rocks of the Losee Metamorphic Suite in the New Jersey Highlands. Geochemical data for the samples plotted are in table 1 .

\section{CHARNOCKITIC ROCKS}

Charnockitic rocks that contain $>5$ modal percent hypersthene in the New Jersey Highlands are of two distinct types as mapped for the new geologic map of New Jersey (Drake and others, 1996): quartz-rich, layered gneiss mapped as hypersthene-quartz-plagioclase gneiss (Yh) and massive-textured, generally quartz-poor rock mapped as diorite $(\mathrm{Yd})$. The latter ranges in composition from hypersthene diorite (norite) to hypersthene tonalite (enderbite). All charnockitic rocks contain minor to moderate amounts of interlayered amphibolite (Ya) dominantly composed of hornblende and andesine. Although detailed chemistry is lacking for these amphibolites, they probably are compositionally similar to amphibolites associated with dacitic, tonalitic, and trondhjemitic rocks and are metamorphosed 


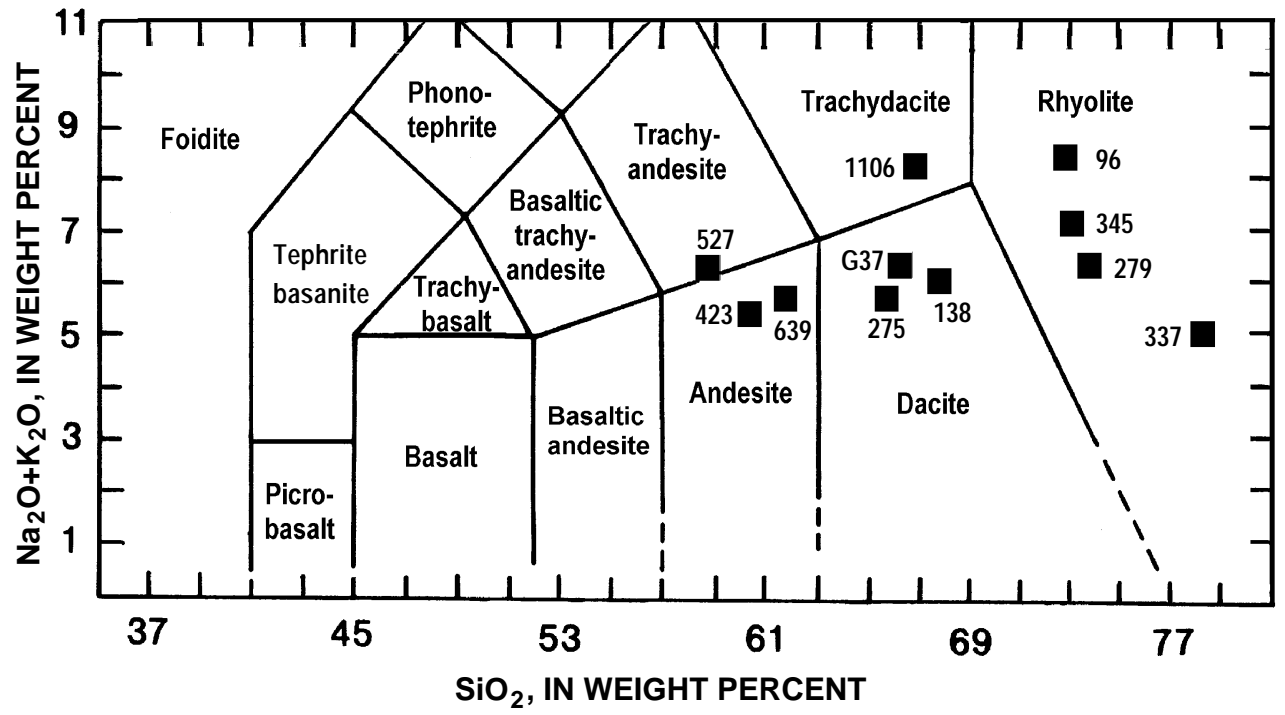

Figure 5. Total alkali-silica plot (LeBas and others, 1986) showing the andesitic, dacitic, and rhyolitic affinities of layered charnockitic rocks of the Losee Metamorphic Suite in the New Jersey Highlands. Major-oxide concentrations of the samples plotted are in table 2 . basalt and (or) gabbro. Both types of charnockitic rock are spatially associated with the more leucocratic rocks of the Losee Metamorphic Suite (fig. 2) but are less extensive areally. Layered, quartz-rich charnockitic gneiss has been mapped throughout the Highlands but is most abundant in the Franklin, Greenwood Lake, and Wanaque quadrangles. Rocks mapped as diorite are sparse west of the Green Pond Mountain region with the exception of a few small exposures mapped by Volkert and others (1989) in the southeastern part of the Stanhope quadrangle. Diorite is abundantly exposed in the Greenwood Lake, Wanaque, Dover, Morristown, and Mendham quadrangles.

The layered charnockitic rocks typically weather gray to tan, are greenish gray to brownish gray, have a greasy luster, and are medium to medium coarse grained. They are composed of plagioclase (oligoclase to andesine), quartz, clinopyroxene, hornblende, biotite, hypersthene, minor potassium feldspar, and opaque minerals. Graphite is a very local accessory in a few exposures in the Franklin and Newfoundland quadrangles. Layered charnockitic gneiss is commonly interlayered with amphibolite and mafic-rich quartzplagioclase gneiss that lacks hypersthene and is of Losee affinity. Exposures of quartz-oligoclase gneiss, quartz-rich charnockitic gneiss, and amphibolite are repetitiously layered on a scale of a few feet in the Newfoundland quadrangle and less abundantly in the Wanaque quadrangle and are strongly suggestive of a metamorphosed pile of volcanic rocks.

On the basis of normative feldspar ratios and majorand trace-element abundances (table 2), particularly plots of $\mathrm{SiO}_{2}$ versus $\mathrm{Na}_{2} \mathrm{O}+\mathrm{K}_{2} \mathrm{O}$ (fig. 5) and ratios of $\mathrm{Zr} / \mathrm{TiO}_{2}$ and $\mathrm{K}_{2} \mathrm{O} / \mathrm{Na}_{2} \mathrm{O}$, the layered charnockitic rocks may be subdivided into rocks having the composition of dacite, andesite, or rhyolite. Charnockitic dacite (table 2, nos. 138, $\mathrm{G} 37,1106$, and 275) has $\mathrm{Zr} / \mathrm{TiO}_{2}$ ratios of $0.025-0.040$ and $\mathrm{K}_{2} \mathrm{O} / \mathrm{Na}_{2} \mathrm{O}$ ratios of $0.20-1.37$. The composition overlaps virtually all major- and trace-element abundances in the leucocratic rocks of the Losee Metamorphic Suite (table 1). The only difference is a very slight enrichment in $\mathrm{K}_{2} \mathrm{O}$ in charnockitic dacite.

Charnockitic andesite (table 2, nos. 423, 639, and 527) has $\mathrm{Zr} / \mathrm{TiO}_{2}$ ratios of $0.015-0.018$ and $\mathrm{K}_{2} \mathrm{O} / \mathrm{Na}_{2} \mathrm{O}$ ratios of 0.37-0.56. It has somewhat lower $\mathrm{SiO}_{2}$ contents and higher $\mathrm{Fe}_{2} \mathrm{O}_{3}, \mathrm{FeO}, \mathrm{CaO}, \mathrm{TiO}_{2}, \mathrm{P}_{2} \mathrm{O}_{5}$, and $\mathrm{Cr}$ contents than charnockitic dacite or leucocratic Losee rocks (table 1).

Charnockitic rhyolite (table 2, nos. 279, 345, 96, and 337) has $\mathrm{Zr} / \mathrm{TiO}_{2}$ ratios of $0.046-0.14$ and $\mathrm{K}_{2} \mathrm{O} / \mathrm{Na}_{2} \mathrm{O}$ ratios of 0.20-5.99. It has higher $\mathrm{SiO}_{2}$ and $\mathrm{Ba}$ contents and lower $\mathrm{Al}_{2} \mathrm{O} 3, \mathrm{TiO}_{2}, \mathrm{FeO}$, and $\mathrm{CaO}$ contents than charnockitic dacite or andesite.

Charnockitic dacites are widespread, whereas charnockitic andesite appears to be confined to the Highlands west of the Green Pond Mountain region. Charnockitic rhyolite occurs east and west of the Green Pond Mountain region but is much less abundant than dacite.

The charnockitic rocks of dioritic composition are greenish gray to brownish gray, greasy lustered, and medium to coarse grained; they weather gray to tan. They are composed of plagioclase (oligoclase to andesine), clinopyroxene, hornblende, biotite, hypersthene, minor quartz, and opaque minerals. Garnet is a very local accessory in an exposure of diorite in the Stanhope quadrangle. The massive charnockites are also commonly associated with amphibolite. Cognate inclusions of noritic composition are locally preserved in an exposure of hypersthene diorite in the Boonton quadrangle. The principal differences seen in the field between hypersthene diorite and the layered charnockitic rocks are the massive, indistinctly foliated texture, the generally quartz-poor composition, and the absence of associated mafic quartz-plagioclase gneiss with the hypersthene diorite.

The layered and massive charnockitic rocks are also distinguishable by their geochemistry. On a normative 

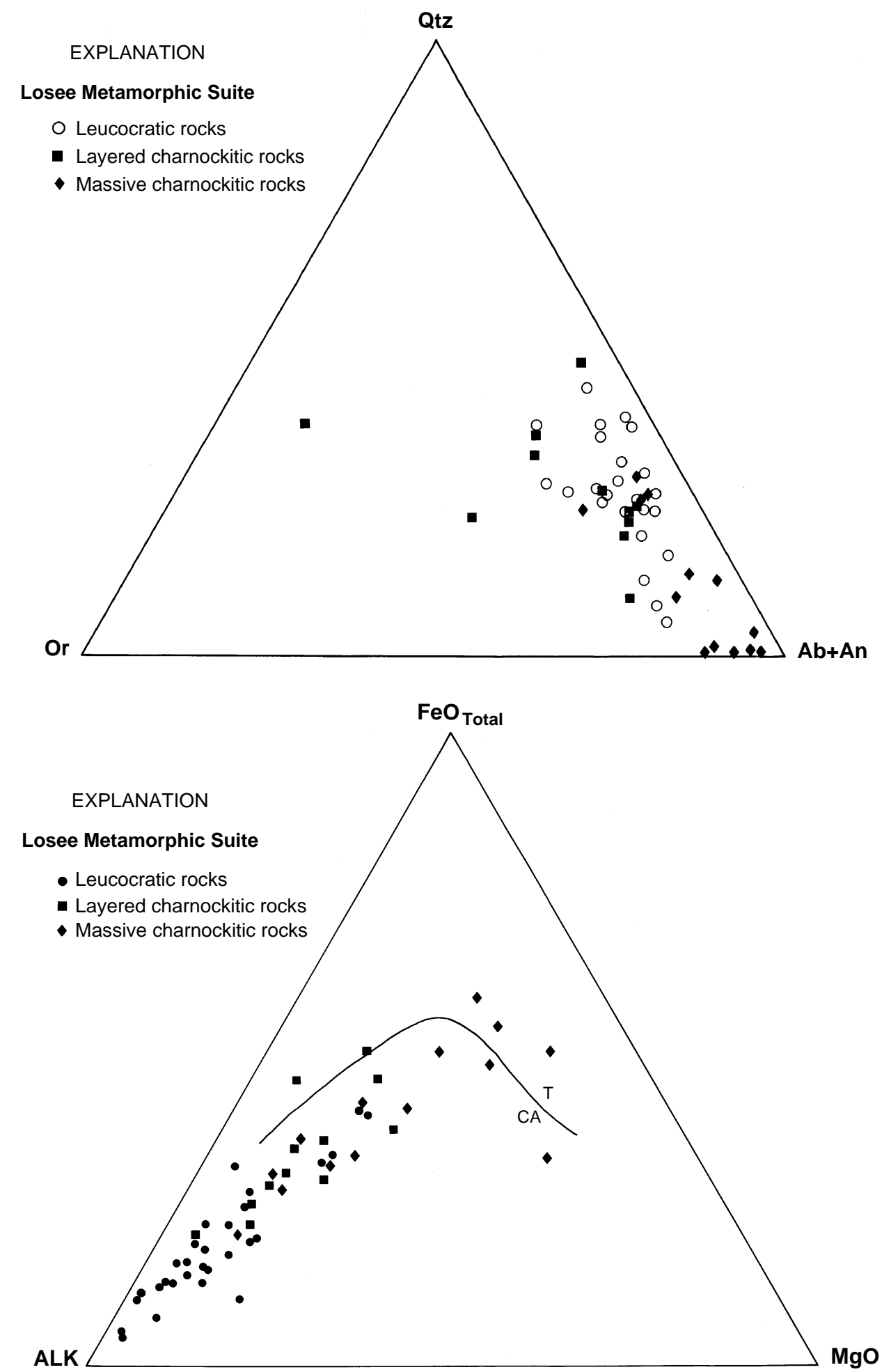

Figure 6. Normative Qtz-Or$(A b+A n)$ diagram of leucocratic rocks, layered charnockitic rocks, and massive charnockitic rocks of the Losee Metamorphic Suite in the New Jersey Highlands. Open circles are used for the leucocratic rocks so that the two separate but overlapping fields defined by the charnockitic rocks can be seen clearly. Geochemical data for the samples plotted are in tables $1-3$.

Figure 7. AFM plot of leucocratic rocks, layered charnockitic rocks, and massive charnockitic rocks of the Losee Metamorphic Suite in the New Jersey Highlands. Line shows boundary between tholeiitic (T) and calc-alkaline (CA) rocks from Irvine and Baragar (1971). ALK $=\mathrm{K}_{2} \mathrm{O}+\mathrm{Na}_{2} \mathrm{O}$ in weight percent. $\mathrm{FeO}_{\text {Total }}$ indicates that all $\mathrm{Fe}$ is reported as $\mathrm{FeO}$. Geochemical data for the samples plotted are from tables $1-3$ and Drake (1984).
Qtz-Or-(Ab+An) diagram (fig. 6), the two rock types fall into separate but overlapping fields. The more siliceous and slightly more potassic composition of the layered charnockites is clearly seen on this diagram. Layered charnockites characteristically contain $>60$ weight percent $\mathrm{SiO}_{2}$. By comparison, massive charnockites contain $<60$ weight percent
$\mathrm{SiO}_{2}$, although a few contain as much as 69 percent and are more properly termed quartz hypersthene diorite or hypersthene tonalite. The massive charnockites have a more mafic composition relative to the layered charnockites that is enriched in $\mathrm{Al}_{2} \mathrm{O}_{3}, \mathrm{FeO}, \mathrm{MgO}$, and $\mathrm{CaO}$ (table 3, fig. 7). The remainder of major oxides and trace elements overlap the 


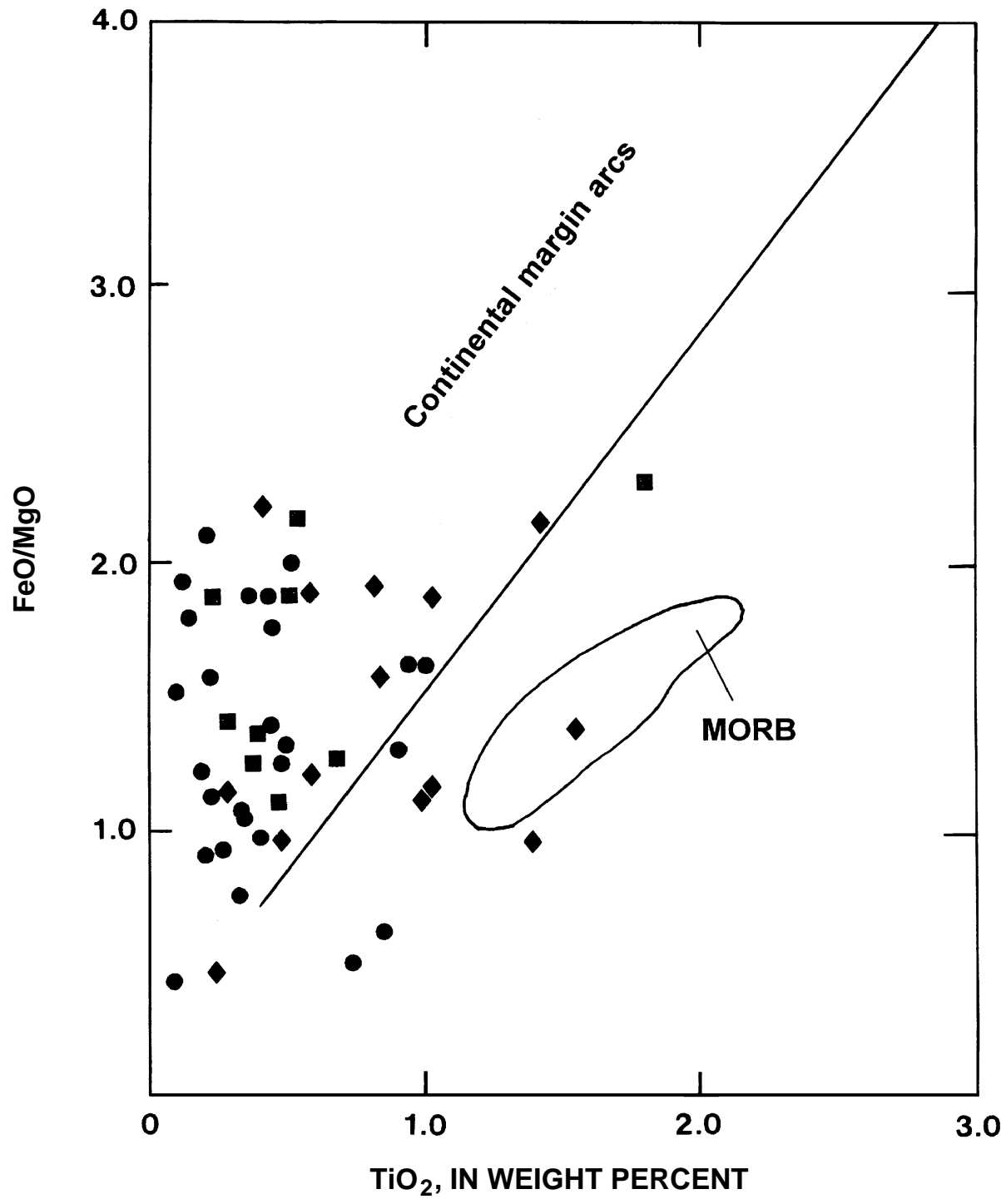

Figure 8. $\mathrm{FeO} / \mathrm{MgO}$ versus $\mathrm{TiO}_{2}$ plot (modified from Kay and others, 1984) of leucocratic rocks, layered charnockitic rocks, and massive charnockitic rocks of the Losee Metamorphic Suite in the New Jersey Highlands. Symbols as in figures 7 and 10. MORB, midocean ridge basalt. Geochemical data for the samples plotted are in tables $1-3$. range of elements in the layered charnockites. Hornblende from hypersthene diorite (not in table 3) mapped in the Gladstone quadrangle (Houghton and Volkert, 1990) contains the following (in weight percent): $\mathrm{SiO}_{2}$ 38.61, $\mathrm{TiO}_{2}$ 4.41, $\mathrm{Al}_{2} \mathrm{O}_{3}$ 14.61, $\mathrm{FeO}_{\text {Total }} 12.31, \mathrm{MgO} 12.60, \mathrm{CaO} 9.66$, $\mathrm{Na}_{2} \mathrm{O}$ 2.63, and $\mathrm{K}_{2} \mathrm{O}$ 1.92; it has the composition of basaltic hornblende.

When researchers (for example, Jakes and White, 1972; Bailey, 1981) use a variety of tectonic discrimination methods based on immobile elements, charnockitic andesites are consistently found to be orogenic andesites and to have an affinity with rocks from continental margin arcs (fig. 8). This affinity is especially supported by their $\mathrm{Al}_{2} \mathrm{O}_{3}, \mathrm{~K}_{2} \mathrm{O}, \mathrm{P}_{2} \mathrm{O}_{5}$, and $\mathrm{Cr}$ contents, which are higher than those of island arc andesites, and their $\mathrm{FeO}_{\mathrm{Total}}, \mathrm{TiO}_{2}, \mathrm{Y}$, and $\mathrm{Zr}$ contents, which are lower. Rocks of rhyodacitic to rhyolitic composition are commonly associated with basalt, andesite, and dacite in orogenic settings. Rocks of rhyolitic composition (table 2, nos. 279, 345, 96, and 337) have now been recognized in association with the Losee and the layered charnockitic rocks.

The origin of charnockitic rocks in New Jersey has been controversial. Drake (1984), Volkert and Drake (1990), and Volkert (1993) have interpreted (1) the layered rocks to be a sequence of metavolcanic rocks including associated basalt and (2) the massive rocks mapped as diorite to be plutonic rocks. Both the layered and massive rocks have a distinct calc-alkaline chemistry readily seen on AFM (fig. 7) and alkali-lime versus $\mathrm{SiO}_{2}$ (fig. 9) diagrams. Together with dacitic, tonalitic, and trondhjemitic rocks, they have an alkali-lime index of about 60 (fig. 9). Layered and massive charnockites fall along the same trend on figures 7 through 9. Volkert (1993) interpreted this sharing of a trend to strongly suggest a petrogenetic relationship between these rock types. Note that the compositions of massive and layered charnockites and the leucocratic Losee rocks overlap 


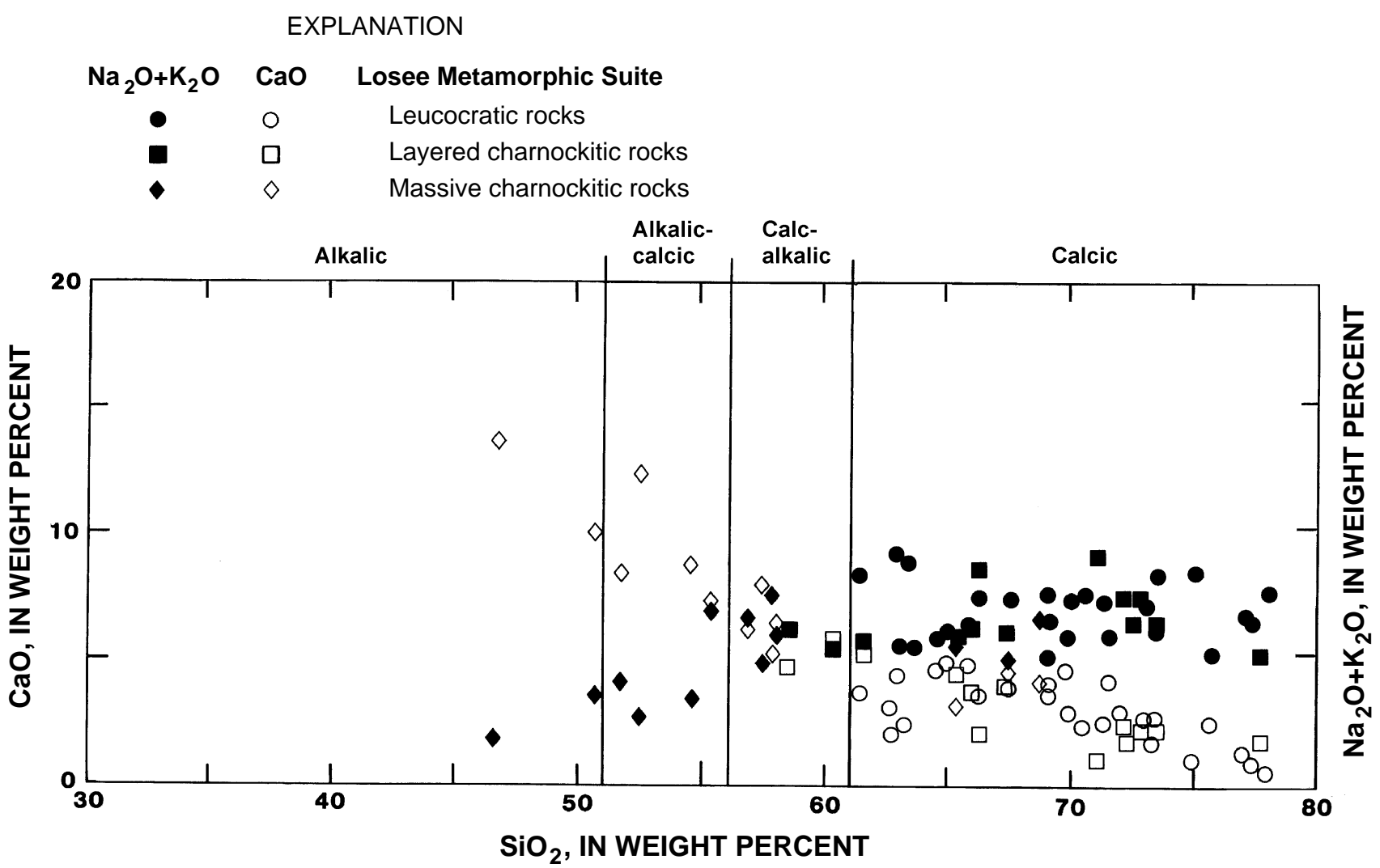

Figure 9. Alkali-lime versus $\mathrm{SiO}_{2}$ plot of leucocratic rocks, layered charnockitic rocks, and massive charnockitic rocks of the Losee Metamorphic Suite in the New Jersey Highlands. Note the well-defined trends and their intersection in the calc-alkalic field. Geochemical data for the samples plotted are in tables $1-3$.

on figure 7. All of these rock types follow the same strong calc-alkaline trend from slight $\mathrm{Fe}$ enrichment in hypersthene diorite to Fe depletion in the layered charnockites and the other Losee rocks. A similar relationship is seen on a $\mathrm{CaO}-\mathrm{Al}_{2} \mathrm{O}_{3}-\left(\mathrm{FeO}_{\text {Total }}+\mathrm{MgO}\right)$ diagram (fig. 10), with both charnockitic rock types and leucocratic Losee rocks defining a single, continuous trend.

Because of the intimate field relationship between the leucocratic Losee rocks and charnockitic rocks, especially in the Newfoundland and Wanaque quadrangles, and also the similarities in the chemistry of both charnockitic rock types, Volkert (1993) interpreted them to have formed in the same continental margin arc that generated the dacite, tonalite, and trondhjemite of the Losee. Partial melting of a basaltic source at lower crustal depths would produce magma having the composition of the hypersthene diorite. Whether the more leucocratic Losee rocks fractionated from this dioritic magma or whether they and the charnockitic rocks are descendents of separate magmas produced by different amounts of partial melting of a parental basalt is difficult to say without isotopic data and further work involving rare-earth-element and selected trace-element geochemistry. At this time, we favor an interpretation involving fractionation of a single parent diorite to produce charnockitic andesite, charnockitic dacite, and the Losee dacite, tonalite, and trondhjemite. This interpretation is particularly supported by the relationships seen in figures 7 and 10, as well as the systematic decrease in $\mathrm{Al}_{2} \mathrm{O}_{3}, \mathrm{FeO}, \mathrm{MgO}$, and $\mathrm{CaO}$ with increasing $\mathrm{SiO}_{2}$ for both types of charnockitic rocks and the leucocratic Losee rocks. Further support comes from the fact that leucocratic Losee rocks typically contain less $\mathrm{Zr}, \mathrm{Ba}$, and $\mathrm{Cr}$ than layered charnockitic rocks. Because these elements also decrease in abundance during fractionation, their lower abundance in leucocratic rocks is consistent with the above interpretation. Therefore, charnockitic rocks and leucocratic rocks of the Losee Metamorphic Suite would be comagmatic. On the basis of field relationships and the geochemical data, we interpret the charnockitic rocks to be cogenetic with dacitic, tonalitic, and trondhjemitic rocks and herein include them all within the Losee Metamorphic Suite that is composed of both calc-alkaline plutonic and metavolcanic rocks.

\section{SUPRACRUSTAL ROCKS}

Unconformably overlying rocks of the Losee Metamorphic Suite in the New Jersey Highlands is a thick 


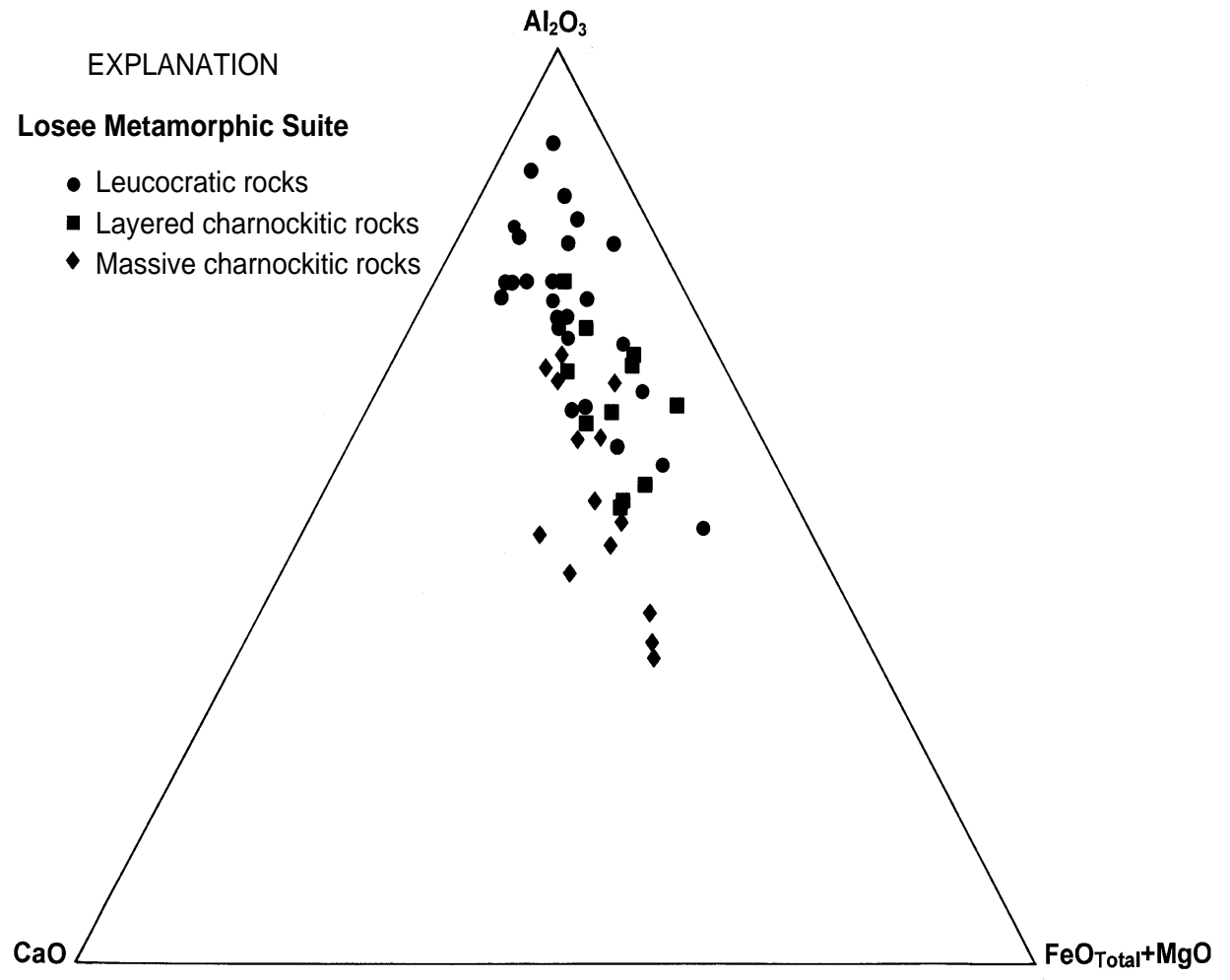

Figure 10. $\mathrm{CaO}-\mathrm{Al}_{2} \mathrm{O}_{3}-\left(\mathrm{FeO}_{\mathrm{Total}^{+}}\right.$ $\mathrm{MgO})$ plot of leucocratic rocks, layered charnockitic rocks, and massive charnockitic rocks of the Losee Metamorphic Suite in the New Jersey Highlands. Note the single trend defined by all three rock types. $\mathrm{FeO}_{\text {Total }}$ indicates that all $\mathrm{Fe}$ is reported as $\mathrm{FeO}$. Geochemical data for the samples plotted are in tables 1-3.

sequence of layered metasedimentary rocks that are quartzofeldspathic gneiss, metaquartzite, calc-silicate gneiss, and marble. Metasedimentary rocks are widespread and abundant in the Highlands both east and west of the Green Pond Mountain region.

\section{QUARTZOFELDSPATHIC GNEISS}

Gneiss and granofels having a quartzofeldspathic composition encompass a wide range of rock types that are mapped as potassium-feldspar gneiss (Yk), microcline gneiss (Ym), monazite gneiss (Ymg), biotite-quartz-feldspar gneiss $(\mathrm{Yb})$, and hornblende-quartz-feldspar gneiss (Ymh). Collectively, these rock types underlie approximately 10 to 15 percent of the New Jersey Highlands. Their spatial distribution is shown in figure 11.

\section{POTASSIUM-FELDSPAR GNEISS}

Potassium-feldspar gneiss (Yk) has been mapped in virtually every quadrangle in the New Jersey Highlands, but it appears to be most abundant in the southwest half of the Highlands. It is a light-pinkish-white or buff, medium- to medium-coarse-grained, moderately foliated gneiss and lesser granofels containing quartz, microcline, oligoclase and local accessory biotite, garnet, sillimanite, and magnetite. Potassium feldspar predominates over plagioclase.

Potassium-feldspar gneiss characteristically contains $>70$ weight percent $\mathrm{SiO}_{2}$ and $>3.5$ weight percent $\mathrm{K}_{2} \mathrm{O}$ (table 4). The iron content is variable but typically is low, as are contents of $\mathrm{CaO}$ and $\mathrm{MgO}$. Samples analyzed by Drake (1984) from the southwestern Highlands contain slightly less $\mathrm{CaO}$ and $\mathrm{Na}_{2} \mathrm{O}$, but otherwise the chemistry of this unit is reasonably uniform throughout the Highlands. On a diagram of molar $\mathrm{Si} /(\mathrm{Si}+\mathrm{Al})$ versus molar $(\mathrm{Na}+\mathrm{Ca}) /(\mathrm{Na}+\mathrm{Ca}+$ K) (fig. 12), potassium-feldspar gneiss spans the fields of arkose, lithic arenite, and graywacke. The overall chemistry of potassium-feldspar gneiss is very close to that of rhyolite. However, several things argue against a metavolcanic protolith for this unit. These include the presence of interlayered quartzite with which potassium-feldspar gneiss locally has gradational contacts, lithologic association with calc-silicate rocks of known sedimentary parentage, highly variable trace-element contents (especially $\mathrm{Zr}$ and $\mathrm{Nb}$ ), and the lack of correlation between Niggli $\mathrm{Mg}$ and $\mathrm{Cr}$, which Van De Kamp and others (1976) considered diagnostic of sedimentary rock. Therefore, an arkosic sandstone is the most likely protolith for potassium-feldspar gneiss.

\section{MICROCLINE GNEISS}

Microcline gneiss (Ym), as first recognized by New Jersey Zinc Company geologists (Hague and others, 1956), occurs sporadically throughout the northern New Jersey Highlands but is most abundant in the Unionville, Hamburg, Newton East, Stanhope, and Tranquility quadrangles. It is a pinkish-white, fine- to medium-grained, well-layered and foliated gneiss composed of quartz, microcline, and 


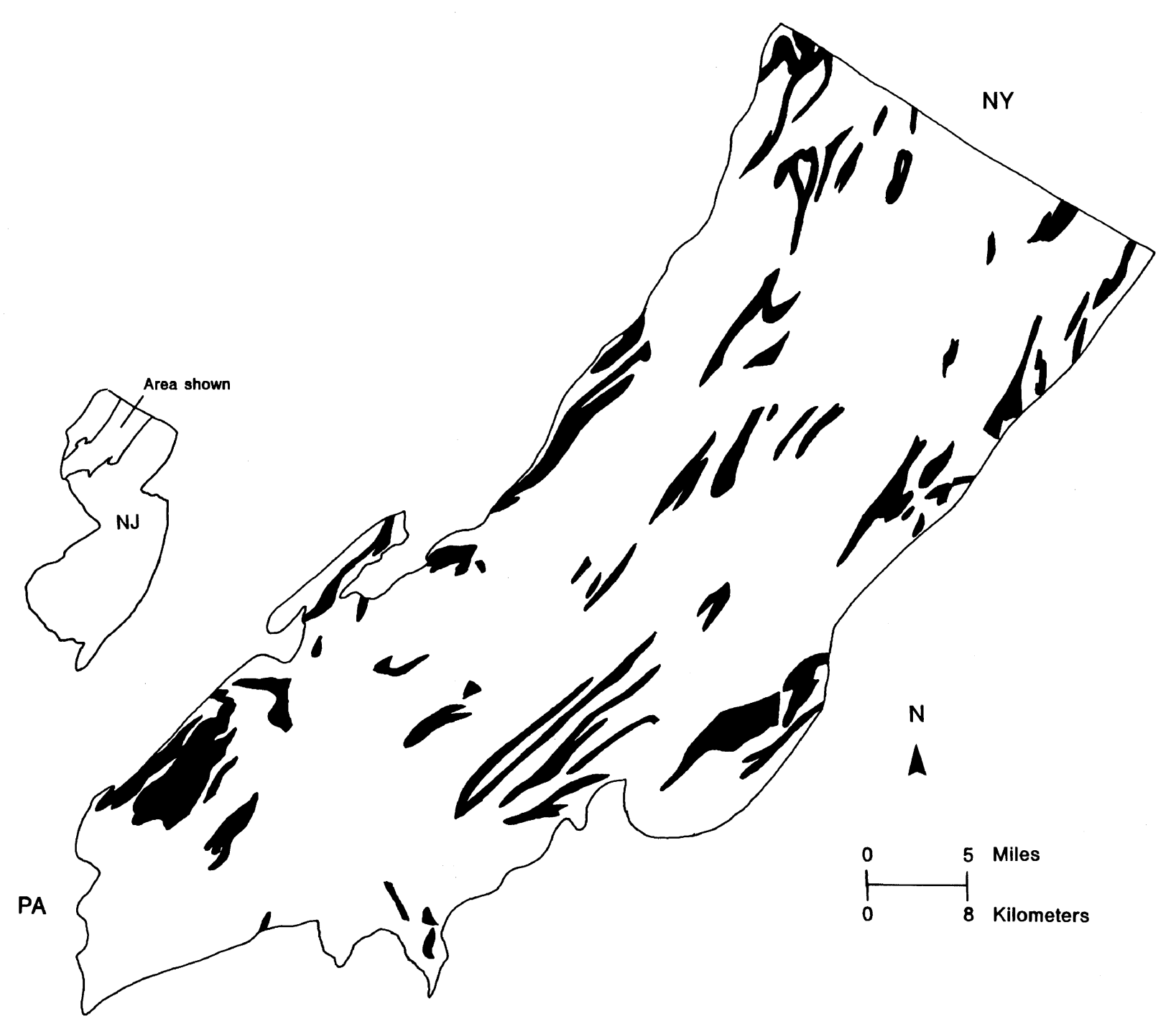

Figure 11. Distribution of rocks of quartzofeldspathic composition in the New Jersey Highlands. Modified from Drake and others (1996).

oligoclase. Common accessory minerals are biotite, garnet, sillimanite, and magnetite. Potassium feldspar predominates over plagioclase.

Microcline gneiss (table 5) is characterized by $\mathrm{SiO}_{2}$ contents similar to those of potassium-feldspar gneiss (table 4) but contains more $\mathrm{K}_{2} \mathrm{O}$ and slightly less $\mathrm{CaO}$. Other major- and trace-element abundances are similar to those in potassium-feldspar gneiss. In figure 12, microcline gneiss has a more restricted range than potassium-feldspar gneiss and falls almost completely within the arkose field. On the basis of field relationships, Volkert (1993) speculated that microcline gneiss and potassium-feldspar gneiss may be sedimentary facies equivalents that differ mainly in texture. Despite the gross similarity between these two rock types, they are mapped as separate units because of the well-layered texture of microcline gneiss, its predominant occurrence in a linear belt in the northwestern New Jersey Highlands, and the somewhat broader range of compositions represented by potassium-feldspar gneiss (fig. 12). The protolith of microcline gneiss is interpreted to be an arkosic sandstone rather than rhyolite for the same reasons outlined above for potassium-feldspar gneiss.

\section{MONAZITE GNEISS}

Quartzofeldspathic gneiss containing abundant monazite, as first recognized by Markewicz (ca. 1965), is unique and very restricted in occurrence. Monazite gneiss (Ymg) is confined to two exposures. The larger is a single, poorly exposed layer approximately $500 \mathrm{ft}$ thick that was mapped 


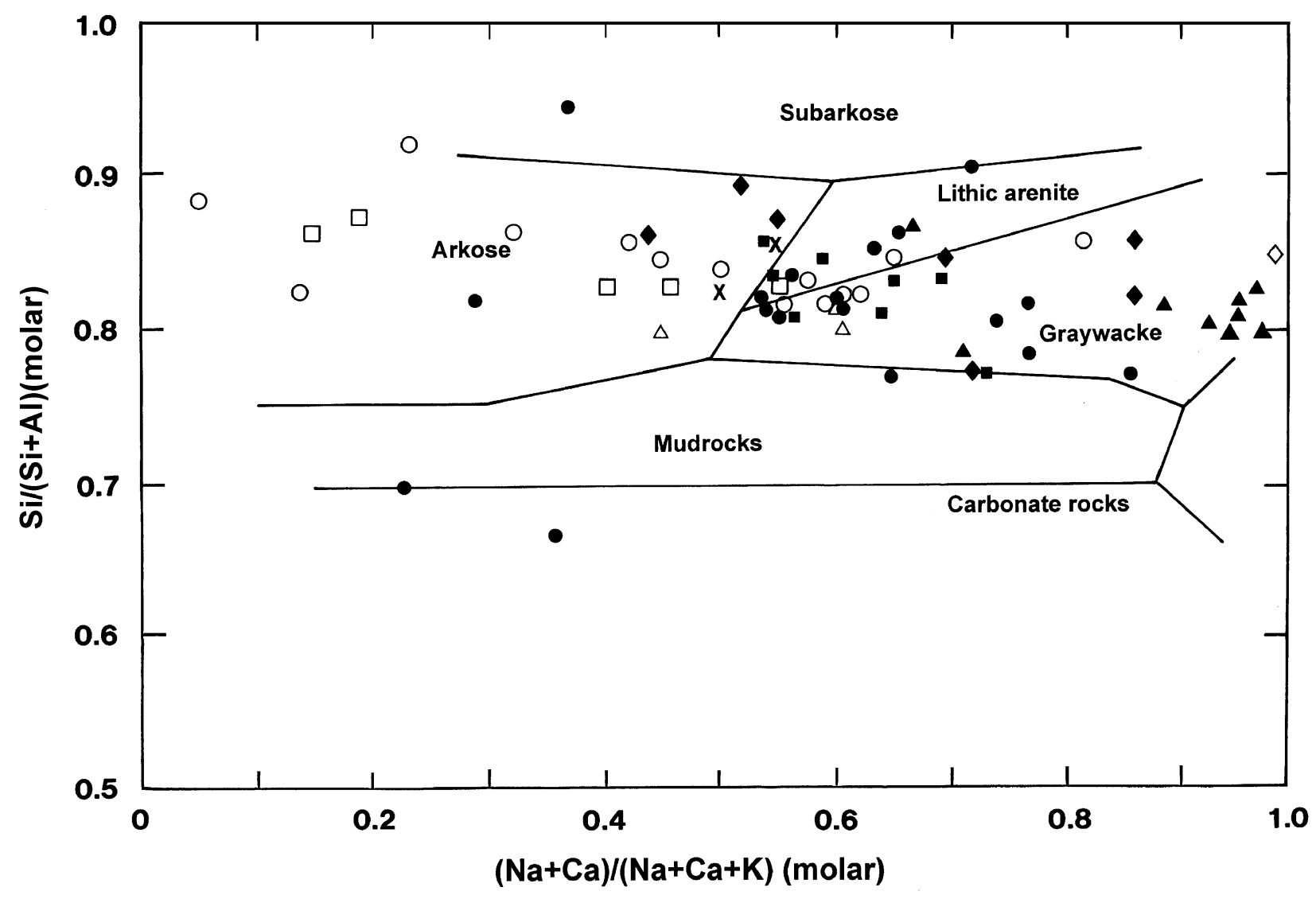

EXPLANATION

\section{Potassium-feldspar gneiss \\ $\square$ Microcline gneiss \\ - Biotite-quartz-feldspar gneiss}

$\Delta$ Hornblende-quartz-feldspar gneiss

\author{
- Clinopyroxene-quartz-feldspar gneiss \\ $\Delta$ Pyroxene gneiss \\ - Pyroxene-epidote gneiss \\ $\diamond$ Quartz-epidote gneiss \\ $X$ Monazite gneiss
}

Figure 12. $\mathrm{Si} /(\mathrm{Si}+\mathrm{Al})$ versus $(\mathrm{Na}+\mathrm{Ca}) /(\mathrm{Na}+\mathrm{Ca}+\mathrm{K})$ (mole percent) plot (Garrels and McKenzie, 1971) for metasedimentary rock types in the New Jersey Highlands. Major-oxide concentrations of the samples plotted are in tables 4-8, 11, and 13.

in the Chester quadrangle (Volkert and others, 1990) and the Hackettstown quadrangle (Volkert and others, 1995), largely on the basis of float and the strong signature of this unit on aeroradiometric maps. A small body of monazite gneiss of indeterminate thickness was also mapped in the Bernardsville quadrangle (Volkert, unpub. data).

Monazite gneiss is a light-greenish-gray to greenish-buff, medium-grained, massive, moderately foliated rock composed of microperthite, quartz, oligoclase, biotite, and monazite. Accessory minerals include hornblende and magnetite. Monazite occurs as small, reddish-brown, resinous grains that constitute $<1$ modal percent in most specimens; some rocks contain as much as 15 percent monazite.

In the Chester, Hackettstown, and Bernardsville quadrangles, monazite gneiss is in conformable contact with rocks of known metasedimentary parentage. Chemical compositions of samples from the Chester and Bernardsville quadrangles are very similar (table 4, nos. C81 and 19) and confirm that these rocks can be placed in the same map unit. Both samples have chemical compositions overlapping that of potassium-feldspar gneiss. In addition, the monazite gneiss has a mineralogy similar to that of potassium-feldspar gneiss. Therefore, monazite gneiss is similarly interpreted to be a metasedimentary rock. In figure 12 , both samples of monazite gneiss fall in the field of arkose. The monazite in this unit may be detrital and was interpreted by Volkert (1993) to represent a small fluvial placer of material eroded from an uplifted continental source that, at least locally, was monazite bearing.

\section{BIOTITE-QUARTZ-FELDSPAR GNEISS}

Biotite-quartz-feldspar gneiss ( $\mathrm{Yb}$ ) occurs throughout the New Jersey Highlands and is equally abundant east and 
west of the Green Pond Mountain region. This unit is variable in texture and composition. It typically weathers pinkish gray, locally weathers rusty, and is a medium- to coarse-grained, moderately layered and foliated rock. The rusty coloration is distinctive where sulfides are abundant. Biotite-quartz-feldspar gneiss is composed principally of quartz, oligoclase, microcline, and biotite. Feldspar proportions are variable, but plagioclase typically predominates over potassium-feldspar. Garnet, sillimanite, and magnetite are common accessory minerals, but graphite is confined to rocks that contain sulfide minerals and weather rusty. Volkert (unpub. data) has mapped locally hornblende-bearing phases of this unit in the Newfoundland, Ramsey, and Blairstown quadrangles. Amphibolite layers are present in both the rusty-weathering and pinkish-gray-weathering phases of this unit but are much more common in the former. Interlayered, locally graphitic metaquartzite layers generally $<5$ feet thick have been mapped within the rustyweathering phase in the Pompton Plains, Morristown, Mendham, High Bridge, and Hackettstown quadrangles (Volkert, unpub. data). Thin, conformably interlayered, graphitic diopsidite (with or without scapolite-bearing gneiss layers) has been observed within this unit in the Pompton Plains and High Bridge quadrangles. In the 19th and early 20th centuries, biotite-quartz-feldspar gneiss was locally exploited for graphite from a number of small mines mainly in the south-central New Jersey Highlands.

The biotite-quartz-feldspar gneiss is characterized by variable $\mathrm{SiO}_{2}$ contents that range from 53 to 88 weight percent and by equally variable $\mathrm{Al}_{2} \mathrm{O}_{3}$ contents that range from about 5 to 23 weight percent (table 6 ). This chemical variability is directly related to the variable quartz content and the amount of garnet and sillimanite in the samples analyzed. Generally, the less siliceous parts of this unit are lithologically associated with quartz-poor calc-silicate rocks and marble. This unit contains higher $\mathrm{Fe}_{2} \mathrm{O}_{3}, \mathrm{FeO}$, and $\mathrm{Na}_{2} \mathrm{O}$ concentrations and lower $\mathrm{K}_{2} \mathrm{O}$ concentrations than potassium-feldspar gneiss or microcline gneiss. There is very little difference overall in the major-oxide compositions of the pinkish-gray- and rusty-weathering phases of this unit (table 6). In figure 12, biotite-quartz-feldspar gneiss falls mainly in the field of graywacke and, to a lesser extent, lithic arenite. Two samples fall close to, or within, the field of pelitic rocks (mudrocks). This field is consistent with the low $\mathrm{SiO}_{2}$ and high $\mathrm{Al}_{2} \mathrm{O}_{3}$ contents of those rocks. One falls in the field of carbonate rocks and probably represents metamorphosed calcareous shale. The scatter seen in figure 12 clearly reflects the heterogeneous composition of the sedimentary protoliths that became this unit.

\section{HORNBLENDE-QUARTZ-FELDSPAR GNEISS}

Hornblende-quartz-feldspar gneiss (Ymh) is best exposed in the Wawayanda and Ramsey quadrangles where thick layers are in conformable contact with calcareous metasedimentary rocks. This unit is pinkish gray, medium grained, and moderately layered and foliated; it is composed of quartz, microcline, lesser oligoclase, and hornblende. Biotite, garnet, and magnetite are minor accessories; titanite is rare.

The few geochemical analyses available for hornblende-quartz-feldspar gneiss (table 7) suggest that it is characterized by an intermediate $\mathrm{SiO}_{2}$ content and high $\mathrm{Al}_{2} \mathrm{O}_{3}$ and $\mathrm{FeO}$ contents. Most of the major-oxide contents overlap those in potassium-feldspar gneiss and biotitequartz-feldspar gneiss, suggesting that this unit is likely a metamorphosed sedimentary rock also. The layered texture and lithologic associations of hornblende-quartz-feldspar gneiss also support this interpretation. The few analyzed samples of this unit fall in the fields of arkose and graywacke in figure 12 .

\section{METAQUARTZITE}

Metaquartzite (Yq) occurs as thin lenses and layers scattered throughout the New Jersey Highlands but is most abundant in the Wanaque quadrangle. It is sparsely exposed, underlying $<1$ percent of the Highlands, but is a lithologically significant unit that provides an excellent stratigraphic and structural marker. Metaquartzite is typically a lightgray, vitreous, medium-grained, massive to well-layered rock. Thin layers of metaquartzite are associated with potassium-feldspar gneiss, biotite-quartz-feldspar gneiss, pyroxene gneiss, epidote gneiss, and marble. The most common and volumetrically important occurrences of metaquartzite are in association with potassium-feldspar gneiss and biotite-quartz-feldspar gneiss. Metaquartzite associated with biotite-quartz-feldspar gneiss occasionally contains up to 40 modal percent graphite and hosts many of the graphite deposits in the Highlands. Minor amounts of biotite, scapolite, and clinopyroxene have also been observed in metaquartzite. Metaquartzite associated with potassium-feldspar gneiss typically contains locally abundant garnet. In the Blairstown and Belvidere quadrangles, metaquartzite associated with potassium-feldspar gneiss contains magnetite- and tourmaline-bearing layers (Volkert, unpub. data). The tourmaline is black and probably is Fe-rich schorl.

There is little question that the bulk of the metaquartzite represents metamorphosed pure and impure quartzose sandstone. Some of the metaquartzite that is associated with calc-silicate gneiss and marble as pods, lenses, and thin layers may be metamorphosed chert.

\section{CALC-SILICATE GNEISS}

Rocks having a calc-silicate affinity encompass a wide range of rock types that were mapped as clinopyroxenequartz-feldspar gneiss (Ymp), pyroxene gneiss (Yp), pyroxene-epidote gneiss (Ype), and quartz-epidote gneiss (Ye). 
Other phases of calc-silicate rock, such as epidote-scapolite-quartz gneiss, diopsidite, and hornblende-pyroxene skarn, were recognized but are not extensive enough to be mapped separately. They are minor variants of the calc-silicate units shown on the new State geologic map (Drake and others, 1996). Collectively, calc-silicate rocks underlie approximately 7 to 10 percent of the New Jersey Highlands. Their spatial distribution is shown in figure 13.

\section{CLINOPYROXENE-QUARTZ-FELDSPAR GNEISS}

Clinopyroxene-quartz-feldspar gneiss (Ymp) occurs throughout the New Jersey Highlands but is most abundant in the Wawayanda, Wanaque, Dover, Stanhope, and Chester quadrangles. At least some of the rock in the southwestern Highlands mapped as potassium-feldspar gneiss by earlier workers actually is clinopyroxene-quartz-feldspar gneiss. This unit is important as it represents a transitional lithology that bridges the gap between the quartzofeldspathic and calc-silicate gneisses. It could easily be grouped with the former, but, because of its lithologic associations, it is more appropriately included with the calc-silicate gneisses. Clinopyroxene-quartz-feldspar gneiss is a pinkish-gray, medium-grained, moderately layered and foliated rock containing quartz, microcline, oligoclase, and clinopyroxene. Local accessories include titanite, biotite, epidote, and opaque minerals. Amphibolite or pyroxene amphibolite is commonly layered with this unit. Clinopyroxene-quartzfeldspar gneiss is spatially associated with a quartz-rich phase of pyroxene gneiss ( $\mathrm{Yp}$ ) in many places, and the two units may have a sedimentary facies relationship.

Clinopyroxene-quartz-feldspar gneiss typically contains 60 to 75 weight percent $\mathrm{SiO}_{2}, 10$ to 14 weight percent $\mathrm{Al}_{2} \mathrm{O}_{3}, 1$ to 6 weight percent $\mathrm{CaO}$, and appreciable $\mathrm{Na}_{2} \mathrm{O}$ and $\mathrm{K}_{2} \mathrm{O}$ (table 8). This gneiss is slightly higher in $\mathrm{CaO}$ than hornblende-quartz-feldspar gneiss (table 7), but their major-

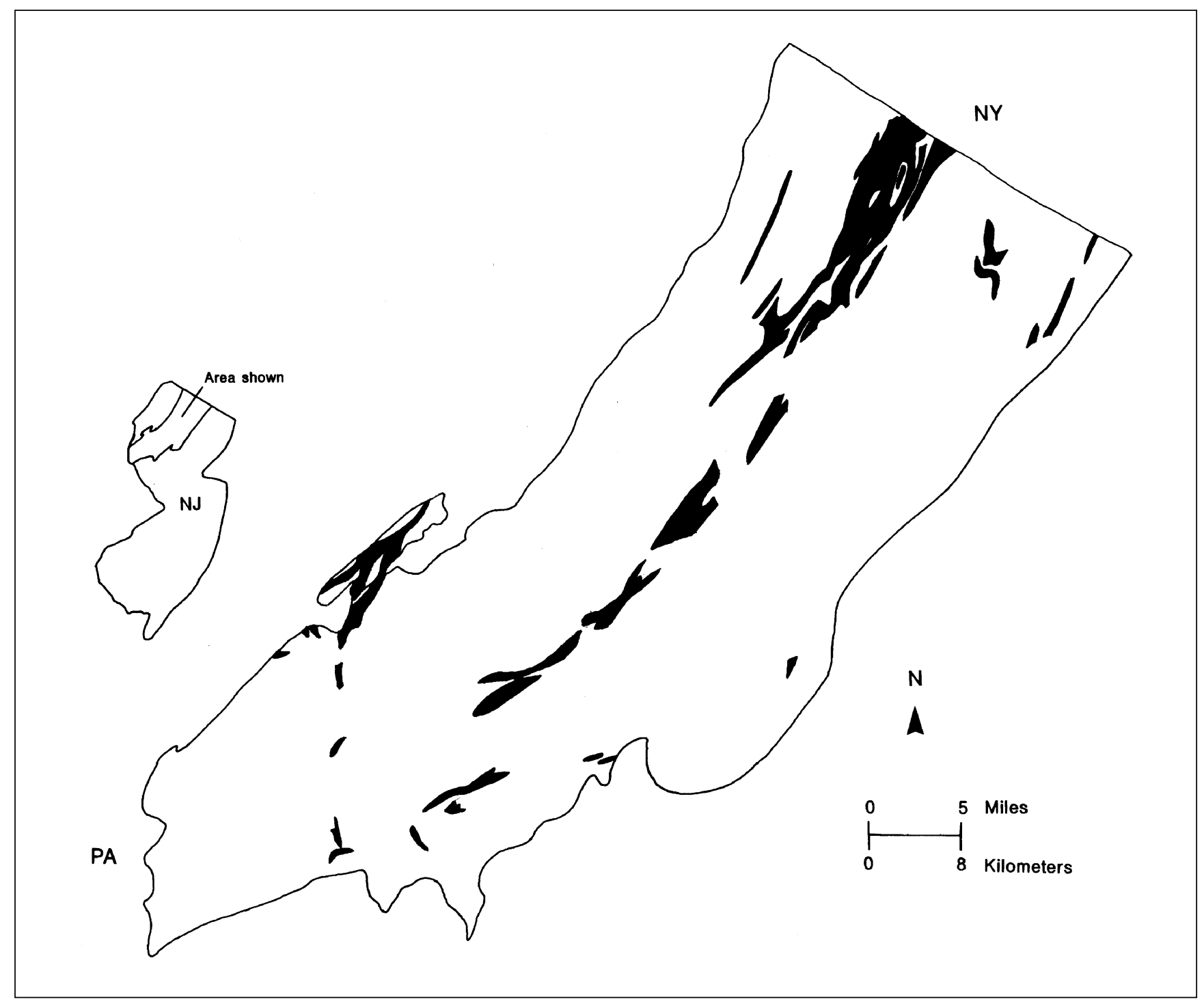

Figure 13. Distribution of rocks of calc-silicate composition in the New Jersey Highlands. Modified from Drake and others (1996). 
oxide contents are otherwise similar. In figure 12, clinopyroxene-quartz-feldspar gneiss spans the fields of arkose, lithic arenite, and graywacke, reflecting variability in the sedimentary protoliths.

\section{DIOPSIDITE}

Occurring very locally within clinopyroxene-quartzfeldspar gneiss and pyroxene gneiss are thin, conformable lenses or layers of light- to medium-green, medium-grained, nearly monomineralic rock composed of clinopyroxene (diopside) and referred to here as diopsidite (fig. 14). These lenses or layers do not exceed a few feet in thickness and are discontinuous over a distance of several tens of feet. For this reason, they were not mapped separately on the new State geologic map (Drake and others, 1996). Volkert (unpub. data) has locally identified these unusual rocks within clinopyroxene-quartz-feldspar gneiss in the Stanhope and Wanaque quadrangles, within pyroxene gneiss in the Tranquility quadrangle, and within rusty biotite-quartz-feldspar gneiss in the Pompton Plains quadrangle. Kastelic (1979) observed a similar diopsidite rock within pyroxene gneiss near the Washington mine in the Washington quadrangle. Sample GL-N (table 9) represents a transitional rock type between nearly monomineralic diopsidite and quartz-poor pyroxene gneiss. It is discussed here and included with pyroxene gneiss for that reason. Chemical analyses of diopsidite (table 9) typically have low $\mathrm{SiO}_{2}$ contents and high $\mathrm{MgO}$ and $\mathrm{CaO}$ contents. All other major-oxide contents are low, including $\mathrm{Al}_{2} \mathrm{O}_{3}$. These rocks are likely metamorphosed lenses and layers of cherty dolomite.

\section{PYROXENE GNEISS}

Pyroxene gneiss (Yp) occurs throughout the New Jersey Highlands but is most abundant west of the Green Pond Mountain region in the Wawayanda, Newfoundland, Franklin, and Hackettstown quadrangles. It is a white- to tan-weathering, greenish-gray, medium-grained, welllayered rock composed of oligoclase, clinopyroxene, and variable amounts of quartz. Clinopyroxene is light to medium green and has a composition between diopside and salite. Microprobe analyses of plagioclase and clinopyroxenes from a sample of quartz-poor pyroxene gneiss from the Gladstone quadrangle are given in table 10 (sample 242, table 11). Titanite and magnetite occur in pyroxene gneiss as accessory minerals. Some variants of this unit are quartz poor and some are quartz rich. Despite this variability, both types were shown together on the new State geologic map (Drake and others, 1996). In the Newfoundland and Wawayanda quadrangles, some phases contain local accessory biotite and (or) hornblende. Graphite has been observed as an accessory in some biotitebearing phases. Amphibolite or pyroxene amphibolite is commonly interlayered with all phases of pyroxene gneiss. Throughout the Highlands, pyroxene gneiss and biotitequartz-feldspar gneiss are in conformable contact and are closely associated. Whereas the latter sometimes occurs alone, few exposures of pyroxene gneiss lack at least minor amounts of biotite-quartz-feldspar gneiss.

Pyroxene gneiss is more variable in chemistry (table 11) than in mineralogy. Pyroxene gneiss is geochemically divisible into $\mathrm{SiO}_{2}$-poor and $\mathrm{SiO}_{2}$-rich types (table 12). The $\mathrm{SiO}_{2}$-poor group (type $\mathrm{A}$ ) is characterized by $<60$ weight

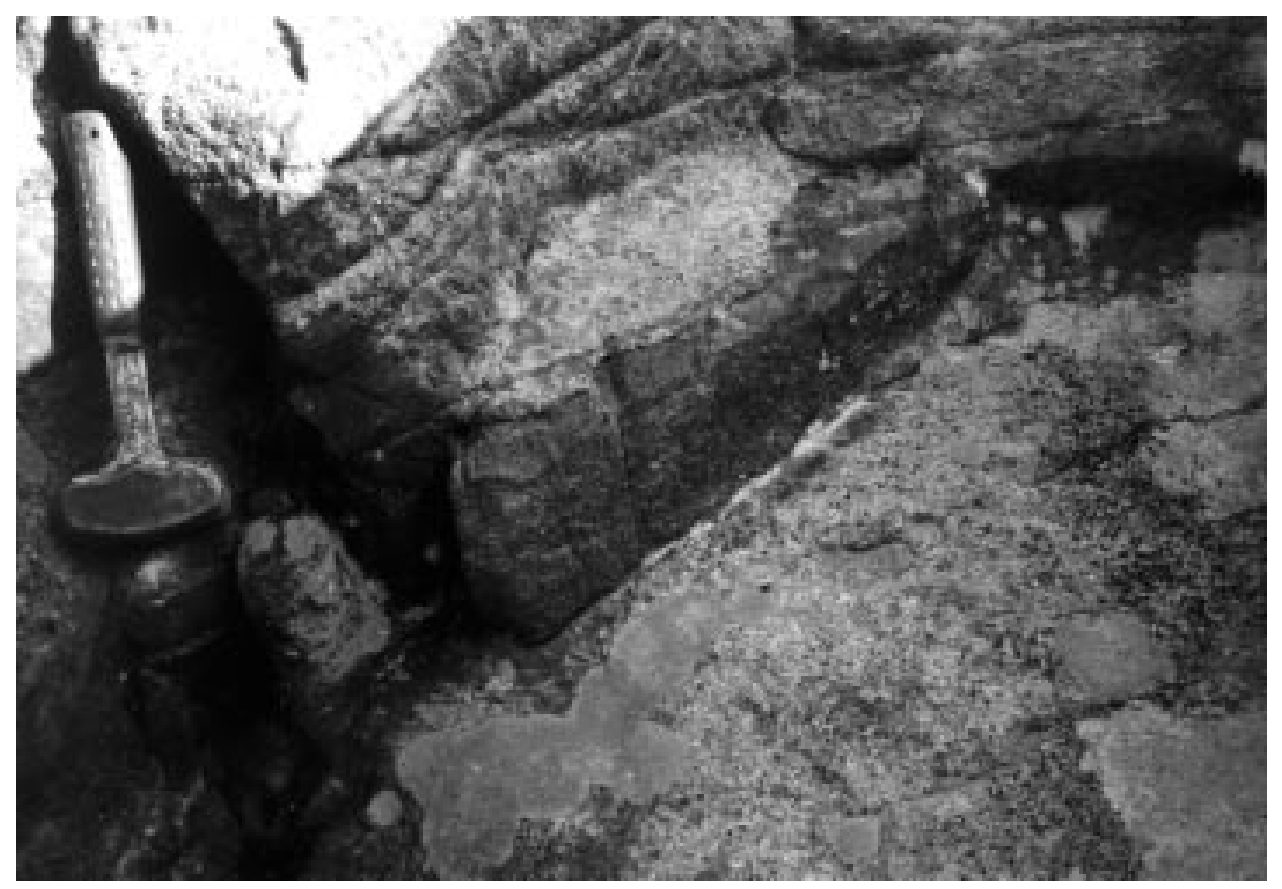

Figure 14. Thin diopsidite lens (center of photograph) within clinopyroxene-quartz-feldspar gneiss from the Stanhope quadrangle, New Jersey. Hammer for scale is $11 \mathrm{in.} \mathrm{long.}$ 
percent $\mathrm{SiO}_{2}$, low $\mathrm{Al}_{2} \mathrm{O}_{3}$, and an enrichment in $\mathrm{FeO}, \mathrm{MgO}$, and $\mathrm{CaO}$ relative to the $\mathrm{SiO}_{2}$-rich group. The sums of $\mathrm{Fe}_{2} \mathrm{O}_{3 \text { Total }}+\mathrm{MgO}$ are $>10$, and the ratios of $\mathrm{Al}_{2} \mathrm{O}_{3} /(\mathrm{CaO}+$ $\mathrm{Na}_{2} \mathrm{O}$ ) are $<0.75$ (fig. 15). The $\mathrm{SiO}_{2}$-rich group (type $\mathrm{B}$ ) contains $>65$ weight percent $\mathrm{SiO}_{2}$. It is further divisible into two subgroups having intermediate $\mathrm{CaO}$ contents (type $\mathrm{B}_{1}$ ) and low $\mathrm{CaO}$ contents (type $\mathrm{B}_{2}$ ). Type $\mathrm{B}_{1}$ pyroxene gneiss is characterized by $\mathrm{Fe}_{2} \mathrm{O}_{3 \text { Total }}+\mathrm{MgO}$ sums between 4 and 6 and $\mathrm{Al}_{2} \mathrm{O}_{3} /\left(\mathrm{CaO}+\mathrm{Na}_{2} \mathrm{O}\right)$ ratios between 1 and 2 (fig. 15). Type $\mathrm{B}_{2}$ pyroxene gneiss has $\mathrm{Fe}_{2} \mathrm{O}_{3 \text { Total }}+\mathrm{MgO}$ sums between 1 and 4 and $\mathrm{Al}_{2} \mathrm{O}_{3} /\left(\mathrm{CaO}+\mathrm{Na}_{2} \mathrm{O}\right)$ ratios $>2$ (fig. 15). The significance of the various geochemical variants of pyroxene gneiss is discussed below in relation to inferred depositional environments. In figure 12, practically all pyroxene gneiss falls within the graywacke field. This plot is not surprising given the typically high $\mathrm{Na}_{2} \mathrm{O}$ content and the ubiquitous association and interlayered nature of biotite-quartz-feldspar gneiss and pyroxene gneiss, the latter being a more calcareous facies.

\section{EPIDOTE-BEARING GNEISS}

Epidote-bearing gneisses occur only west of the Green Pond Mountain region and are most abundant in the Franklin, Tranquility, and Washington quadrangles. Two main types are recognized, pyroxene-epidote gneiss (Ype) and quartz-epidote gneiss (Ye), although local mineralogical variants of these two types do exist. Pyroxene-epidote gneiss is a light-greenish-gray, fine- to medium-grained, well-layered rock composed principally of quartz, oligoclase, microcline, clinopyroxene, epidote, and sparse titanite. Pyroxene-epidote gneiss in the Tranquility quadrangle is locally migmatized, containing quartz and feldspar veins and layers. The chemistry of pyroxene-epidote gneiss (table 13) overlaps that of pyroxene gneiss (table 11) in most elements, but pyroxene-epidote gneiss has more $\mathrm{SiO}_{2}$ and $\mathrm{K}_{2} \mathrm{O}$ and less $\mathrm{MgO}$ and $\mathrm{Na}_{2} \mathrm{O}$. Pyroxene-epidote gneiss is interpreted to be related to pyroxene gneiss with which it is spatially associated.

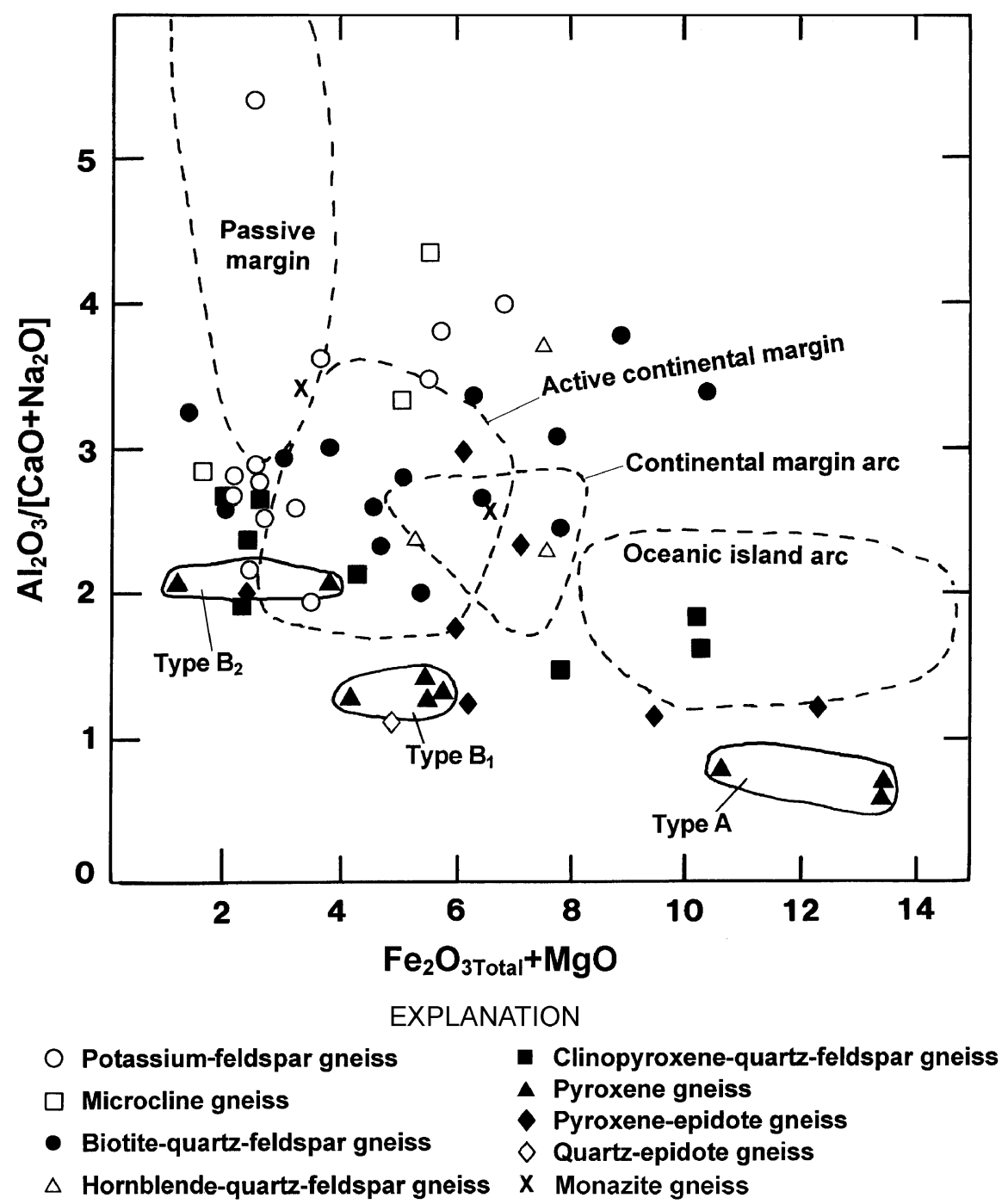

Figure 15. $\mathrm{Al}_{2} \mathrm{O}_{3} /\left(\mathrm{CaO}+\mathrm{Na}_{2} \mathrm{O}\right)$ versus $\mathrm{Fe}_{2} \mathrm{O}_{3 \text { Total }}+\mathrm{MgO}$ plot (Bhatia, 1983) for metasedimentary rocks in the New Jersey Highlands. Solid lines define fields for types $A, B_{1}$, and $B_{2}$ of pyroxene gneiss (Yp). Note the close similarity of some pyroxene-epidote gneiss (Ype, solid diamonds) and quartz-epidote gneiss (Ye, hollow diamond) to pyroxene gneiss. $\mathrm{Fe}_{2} \mathrm{O}_{3 \text { Total }}$ indicates that all $\mathrm{Fe}$ is reported as $\mathrm{Fe}_{2} \mathrm{O}_{3}$. 
With a decrease in epidote and potassium feldspar, pyroxene-epidote gneiss grades into quartz-rich pyroxene gneiss. This gradation was noted in the Washington and Hamburg quadrangles. Therefore, the two rock types may have a facies relation, with pyroxene-epidote gneiss containing a higher volcaniclastic component. Pyroxeneepidote gneiss falls exclusively in the graywacke field in figure 12.

Quartz-epidote gneiss is a similar rock that is typically poorly exposed and very thin. Therefore, it is difficult to map separately. It is not as well layered as pyroxene-epidote gneiss. Quartz-epidote gneiss consists dominantly of quartz, oligoclase, and epidote. Clinopyroxene, titanite, and scapolite are minor accessory minerals. Quartz-epidote gneiss is related to quartz- rich pyroxene gneiss, with which it is spatially associated. The composition of quartz-epidote gneiss (table 13, sample 417E) overlaps that of pyroxene-epidote gneiss except for a slightly higher $\mathrm{Na}_{2} \mathrm{O}$ content and much lower $\mathrm{K}_{2} \mathrm{O}, \mathrm{Ba}$, and $\mathrm{Rb}$ contents in the former.

The protoliths of most calc-silicate gneiss represent some gradation between (1) metamorphosed calcareous, locally volcaniclastic sandstone and shale and (2) quartzose and argillaceous carbonate rocks, the latter being less abundant.

\section{MARBLE}

The name Franklin White Limestone was introduced by Wolff and Brooks (1898) for the marble in the Franklin belt in Sussex County. Because all marble in the New Jersey Highlands was correlated with that at the type locality in Franklin, this is the name shown on the old State geologic map (Lewis and Kümmel, 1912). The name has since been changed to Franklin Marble (Yf) by Drake and others (1991a).

Although widespread, marble underlies only approximately 5 percent of the New Jersey Highlands (fig. 16). It is best exposed west of the Green Pond Mountain region. It is especially abundant in the Wawayanda, Hamburg, Franklin, Blairstown, and Belvidere quadrangles. Most marble is a white to light-gray, medium- to coarsely crystalline, massive to moderately layered, calcitic to locally dolomitic rock. Principal accessory minerals in the Franklin area are graphite, phlogopite, chondrodite, and clinopyroxene. Marble in the Franklin-Ogdensburg area is host to the renowned zinc ore bodies and has been extensively studied by New Jersey Zinc Company geologists (for example, Hague and others, 1956; Metsger and others, 1958).

Other pods, lenses, and layers of marble in the Highlands east of the Green Pond Mountain region are well layered, contain characteristic serpentine minerals, and are associated with talc- and tremolite-bearing rocks. Most of these small bodies were locally quarried for serpentine and (or) crushed lime. They occur in the Wanaque, Pompton
Plains, Mendham, and Belvidere quadrangles. Similar occurrences in the Easton quadrangle were commercially exploited for talc and serpentine minerals (Peck, 1904). Some marble in the Wanaque quadrangle is layered with metaquartzite that was locally mined for graphite. All of these bodies of marble are spatially associated with the same rocks as marble in the Franklin area. Therefore, at this time, all marble is chronocorrelated with the Franklin, although it is recognized that not all marble in the Highlands occurs at the same stratigraphic level. In the northern Highlands, New Jersey Zinc Company geologists (Hague and others, 1956) separated marble into the lower Franklin band approximately 1,100 to 1,500 feet thick and the upper Wildcat band approximately 300 feet thick. These marble bands are separated by a heterogeneous sequence of metasedimentary rocks ranging in thickness from 500 to 1,900 feet.

All workers in the Highlands agree that the marble is metamorphosed limestone and lesser dolomitic limestone that contains pods, lenses, and layers of calcareous and quartzose metasedimentary rocks, amphibolite from an unknown protolith, and metaquartzite.

Some constraint on a minimum age for the Franklin Marble is provided by an age obtained from galena in a marble "dike" from a gneiss fragment. This fragment was collected in the core of the ore body at the Sterling Hill zinc mine in Ogdensburg. According to Metsger (1977), the galena, unquestionably younger than the enclosing gneiss or marble, yielded a ${ }^{207} \mathrm{~Pb} /{ }^{206} \mathrm{~Pb}$ age of $1,100 \mathrm{Ma}$.

\section{STRATIGRAPHIC RELATIONS AND TECTONIC SETTING}

Interpreting the stratigraphic relationships among the Middle Proterozoic metasedimentary rocks in the New Jersey Highlands is a vexing problem. Three factors hinder interpretation: (1) the obliteration of primary sedimentary features and the masking of the original sedimentary parentage during Grenvillian high-grade metamorphism, (2) the obscuring of stratigraphic relations by large volumes of intrusive rock, and (3) the lack of geochronologic data to constrain the overall sequence. Bounding ages for the metasedimentary sequence are provided by rocks dated elsewhere that are analogous to the Losee Metamorphic Suite and, as discussed in the next section, the younger Byram and Lake Hopatcong Intrusive Suites. However, the relative ages of the metasedimentary rocks are unknown. Past and present sedimentary basinal analogs may instead be used for comparison. In the previous section, detailed geochemistry was used to identify reasonable protoliths. These allow the development of an appropriate, if speculative, sedimentary framework.

The Losee Metamorphic Suite rocks, including the charnockitic rocks, are assumed to be basement to the other 


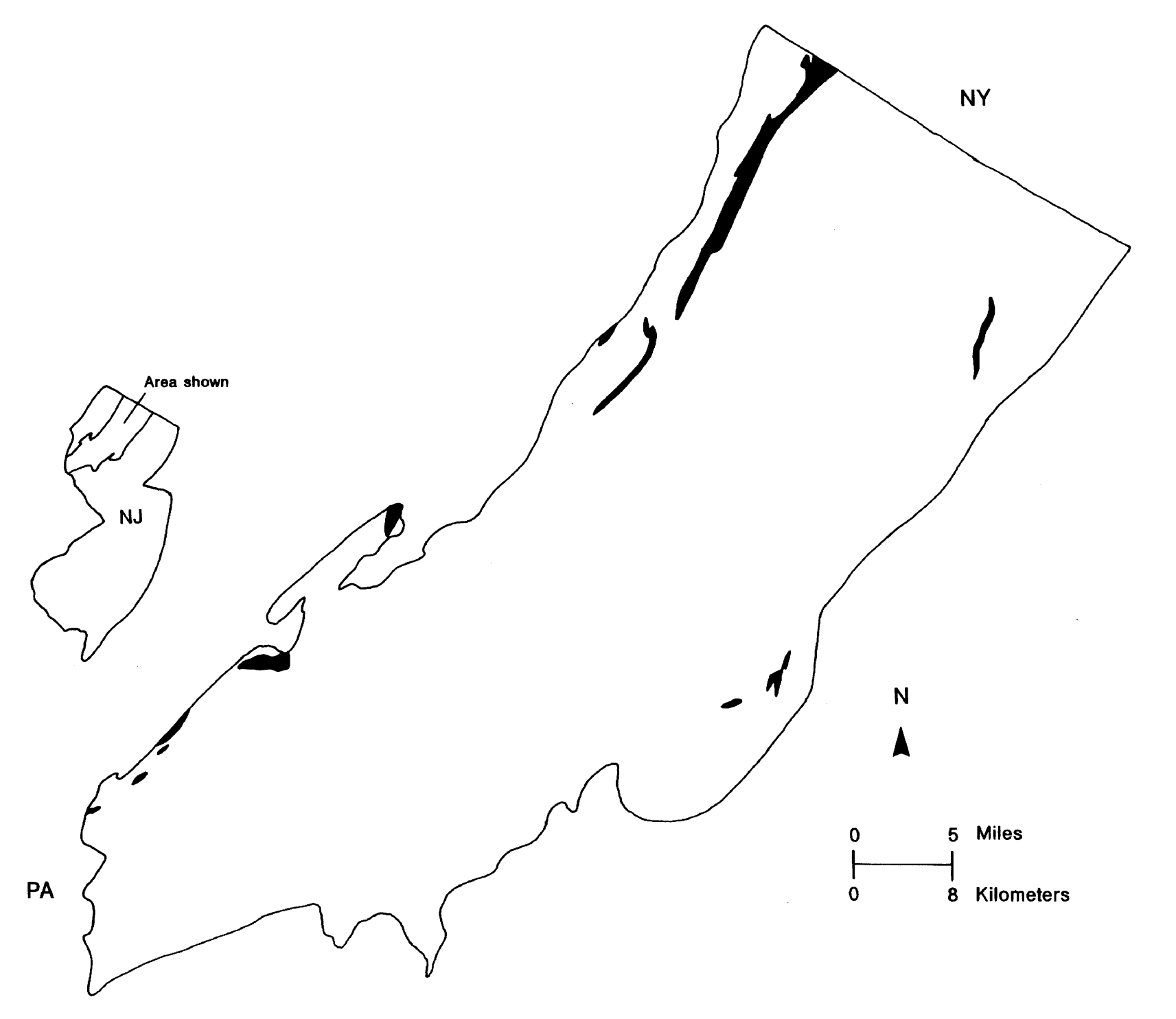

Figure 16. Distribution of marble in the New Jersey Highlands. Modified from Drake and others (1996).

Middle Proterozoic rocks; therefore, the unconformably overlying quartzite and associated potassium-feldspar gneiss in the Wanaque quadrangle may be among the oldest, if not the oldest, metasedimentary rocks in the Highlands. The arkosic rocks, which include potassium-feldspar gneiss, microcline gneiss, and possibly monazite gneiss (fig. 12), likely collected in a block-faulted or downwarped basin within a craton in an extensional tectonic setting. This depositional setting is supported by the tectonic discrimination diagrams of Blatt and others (1972) (fig. 17) and Roser and Korsch (1986) (fig. 18).

Sediments that formed the arkosic rocks were derived largely from granitic or rhyolitic sources. A potassic source is a problem because the underlying basement rocks are interpreted to have been dominantly calc-alkaline and plagioclase rich. As stated above, rhyolite is commonly associated with basalt and dacite in orogenic settings. Erosion of a rhyolitic source cogenetic with rocks of the Losee Metamorphic Suite could have provided detritus of the appropriate composition for an arkose and would explain the apparent paucity of rhyolites in the Highlands at the present level of erosion. In our basinal interpretation, continued erosion of the craton altered the character of the sediment deposited to that of lithic arenite, reflecting deposition of different source material in a fluvial to shallow-marine environment. Unfortunately, the stratigraphy above the aforementioned unconformity is unknown, as the metaquartzite and potassium-feldspar gneiss are surrounded by rocks of the Losee Metamorphic Suite as well as the Byram Intrusive Suite. Elsewhere in the New 


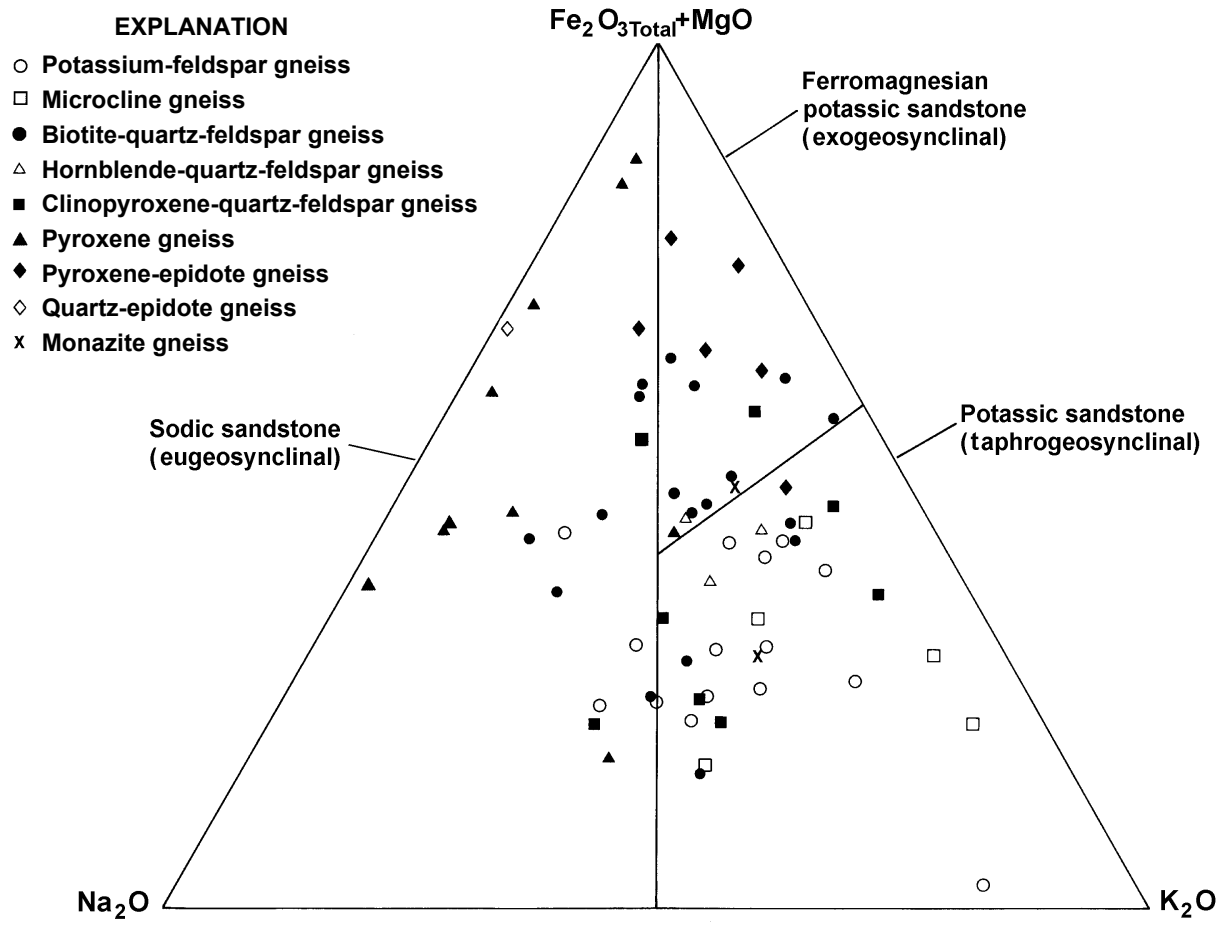

Figure 17. $\mathrm{Na}_{2} \mathrm{O}-\left(\mathrm{Fe}_{2} \mathrm{O}_{3 \text { Total }^{+}}{ }^{+}\right.$ $\mathrm{MgO})-\mathrm{K}_{2} \mathrm{O}$ diagram (Blatt and others, 1972) showing chemical composition of New Jersey Highlands metasedimentary rocks in relation to tectonic setting.
Jersey Highlands outside the Wanaque quadrangle, the stratigraphic order of the fluvial and shallow-marine sequence appears to be potassium-feldspar gneiss, followed by biotite-quartz-feldspar gneiss (with or without intervening hornblende-quartz-feldspar and (or) clinopyroxenequartz-feldspar gneiss), pyroxene gneiss, and marble (with or without intervening pyroxene-epidote gneiss).

The overall stratigraphy of the marine sequence is ambiguous, but reconstruction of partial successions based on field relationships from different parts of the Highlands supports a stratigraphic order of metaquartzite, followed by pyroxene gneiss, marble, other calc-silicate rocks, biotitequartz-feldspar gneiss, and more pyroxene gneiss. Thus, the marine depositional sequence was quartzite, calc-silicate protoliths, limestone, and graywacke of quartzofeldspathic and calc-silicate composition (figs. 17 and 18). The lithofacies in this stratigraphy are not present in the western Highlands. There, marble locally directly overlies arkosic quartzofeldspathic gneiss that was mapped as microcline gneiss with no intervening calc-silicate rocks.

The depositional environment of pyroxene gneiss is reasonably constrained by the geochemical data (tables 11 and 12). The $\mathrm{SiO}_{2}$-poor group (type $\mathrm{A}$ ) has the composition of volcanic graywacke, suggesting that sediments came from an oceanic island arc. This interpretation is further supported by the tectonic discriminants of Bhatia (1983), especially $\mathrm{Fe}_{2} \mathrm{O}_{3 \text { Total }}, \mathrm{MgO}$, and $\mathrm{Al}_{2} \mathrm{O}_{3} /\left(\mathrm{CaO}+\mathrm{Na}_{2} \mathrm{O}\right.$ ) (fig. 15), and also those of Roser and Korsch (1986) (fig. 18). According to the same discriminants, the type $\mathrm{B}_{1} \mathrm{SiO}_{2}$-rich subgroup has characteristics that are transitional between sedimentation in an oceanic island arc setting and sedimentation in an active continental margin setting, whereas the type $\mathrm{B}_{2} \mathrm{SiO}_{2}$-rich subgroup reflects sedimentation in an active continental margin setting (fig. 15). Taken together, the compositions of all three types of pyroxene gneiss show a clear transition from source rocks that were calc-alkaline to tholeiitic and derived from an oceanic magmatic arc to more siliceous source rocks closer in composition to granite and derived from a continental crustal source.

Except for two samples, pyroxene-epidote gneiss plots within or are very close to the fields of type $A$, type $B_{1}$, and type $B_{2}$ pyroxene gneiss (fig. 15), suggesting a likely facies relationship between these two rock types. The transition in compositions of the pyroxene gneiss types indicates that sedimentation probably did not occur in separate basin settings. The difference is mainly one of varying source material that was shed into one basin. Field relationships and geochemical data support a sequence of sedimentation that progressed from $\mathrm{SiO}_{2}$-rich to $\mathrm{SiO}_{2}$-poor rocks.

We interpret the $\mathrm{SiO}_{2}$-rich pyroxene gneiss of continental affinity (type $\mathrm{B}_{2}$ ) to have been deposited in the same extensional tectonic setting as quartzite, marble, and some of the quartzofeldspathic gneisses, whereas the $\mathrm{SiO}_{2}$-poor pyroxene gneiss (type $\mathrm{A}$ ) reflects a transition to a later convergent boundary tectonic setting and the concomitant development of an oceanic island arc. This interpretation is consistent with (1) the progression of type $B_{1}$ and type $B_{2}$ pyroxene gneiss west of the Green Pond Mountain region, where they are associated with predominantly metasedimentary rocks, and with (2) the lithologic associations of 


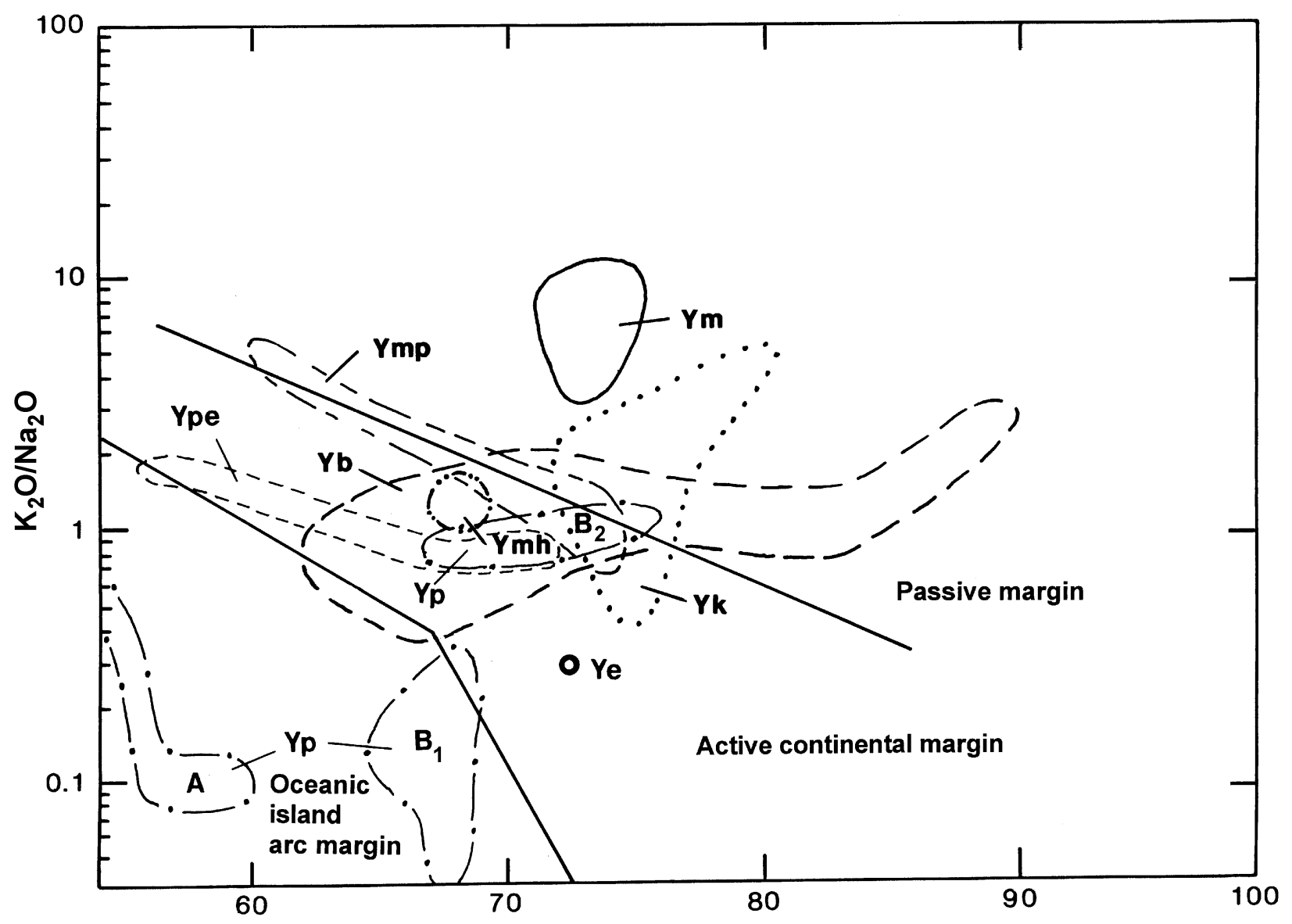

\section{$\mathrm{SiO}_{2}$, IN WEIGHT PERCENT}

Figure 18. Diagram of $\log \mathrm{K}_{2} \mathrm{O} / \mathrm{Na}_{2} \mathrm{O}$ versus $\mathrm{SiO}_{2}$ (Roser and Korsch, 1986) for New Jersey Highlands metasedimentary rocks. Symbols: Ym, microcline gneiss; Yk, potassium-feldspar gneiss; Ymh, hornblende-quartz-feldspar gneiss; Ymp, clinopyroxene-quartz-feldspar gneiss; Yb, biotite-quartz-feldspar gneiss; Ype, pyroxene-epidote gneiss; Ye, quartz-epidote gneiss; and Yp, pyroxene gneiss, including types $\mathrm{A}, \mathrm{B}_{1}$, and $\mathrm{B}_{2}$.

type A pyroxene gneiss east of the Green Pond Mountain region, which are predominantly graywacke (biotitequartz-feldspar gneiss) and basalt (amphibolite).

The occurrence of carbonaceous, sulfidic phases within biotite-quartz-feldspar gneiss and some calc-silicate gneiss indicates that locally stagnant and reducing conditions existed in this marine basin. These rocks represent organicmatter-rich sands and lesser muds that grade into noncarbonaceous and nonsulfidic phases of the same units. The euxinic sediments may have resulted from an oceanward structural high that obstructed circulation and created a less oxygenated environment.

\section{INTRUSIVE ROCKS}

Two suites of synorogenic granite (Byram and Lake Hopatcong Intrusive Suites) and one of postorogenic granite
(Mount Eve Granite) intrude the Losee Metamorphic Suite (including its charnockitic rocks) and the overlying metasedimentary rocks. The spatial distribution of intrusive rocks, which underlie approximately 55 percent of the New Jersey Highlands, is shown in figure 19. The synorogenic granites were initially named the Byram Gneiss by Spencer and others (1908) for exposures at Byram Township in Sussex County and included all granite and gneiss having a potassic composition. Subsequent workers (for example, Hotz, 1953; Sims, 1958) abandoned the name Byram and mapped granitic rocks according to their constituent mineralogy. All granite previously included in the Byram Gneiss consists of hornblende granite (and related rocks) and clinopyroxene granite (and related rocks). Drake (1984) renamed hornblende granite and related rocks the Byram Intrusive Suite. Pyroxene granite and related rocks were named the Lake Hopatcong Intrusive Suite by Drake and 


\section{EXPLANATION}

Mount Eve Granite

Vernon Supersuite

Byram Intrusive Suite

$\square$ Lake Hopatcong Intrusive Suite

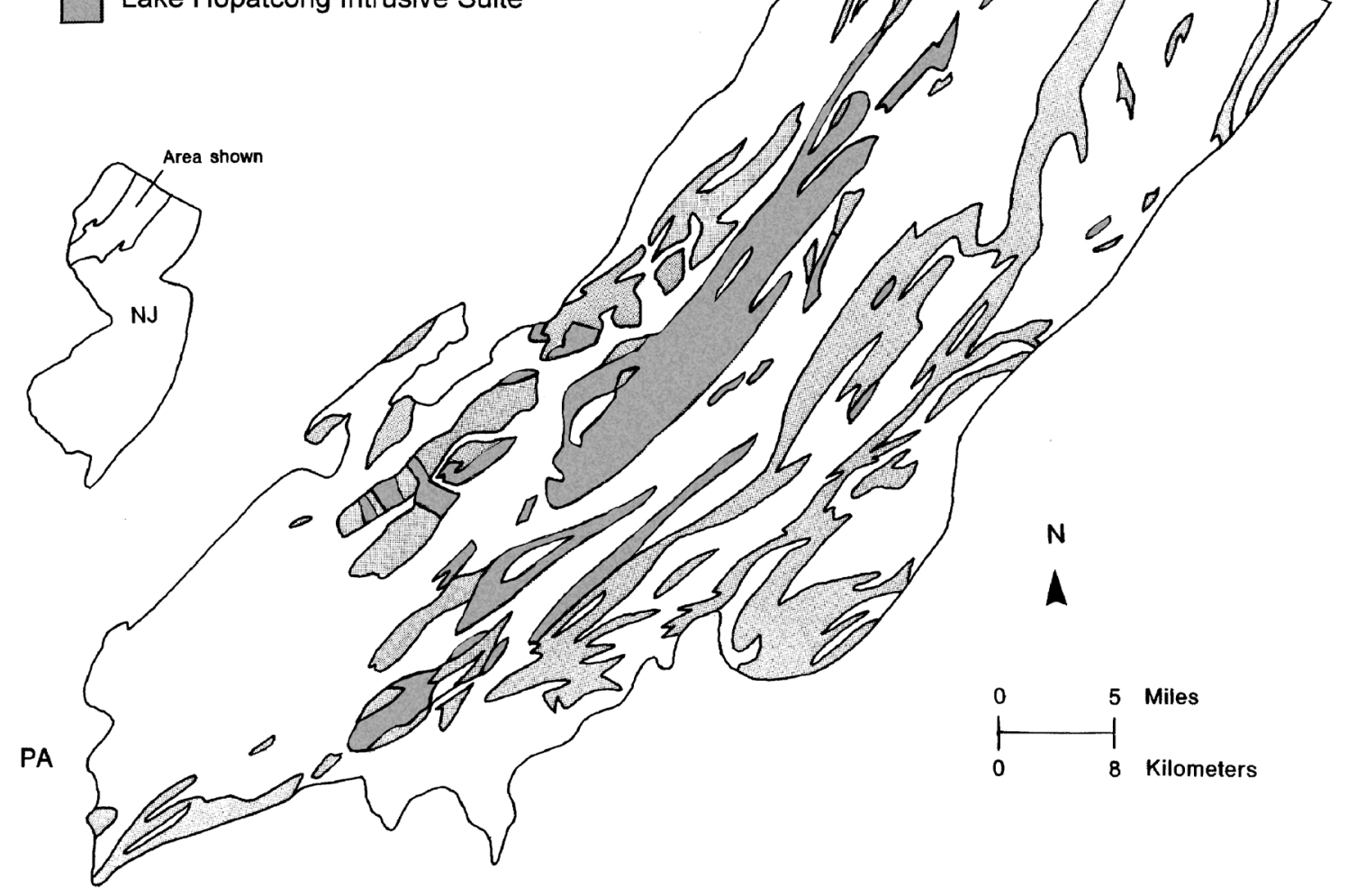

Figure 19. Distribution of intrusive rocks of the Vernon Supersuite and the Mount Eve Granite in the New Jersey Highlands. Modified from Drake and others (1996).

Volkert (1991) for excellent exposures in the Lake Hopatcong area.

For reasons that are detailed in the following discussion, we have interpreted rocks of the Byram and Lake Hopatcong Intrusive Suites to be elements of the Vernon Supersuite (Volkert and Drake, 1998). The Vernon was named for the abundance and diversity of variants of both suites from the Hamburg Mountains in the Hamburg 7.5-minute quadrangle within Vernon Township in Sussex County. Geologic relations of the Vernon Supersuite in the type area are shown in figure 20. Although the name Vernon has already been applied to the Silurian Vernon Shale of New York, these two units are not named for the same feature and there is a great enough disparity in age so that there should be no confusion.

The postorogenic Mount Eve Granite was recognized and mapped by Hague and others (1956) and later was formally named and discussed by Drake and others (1991a). Throughout the following discussion of intrusive rocks, the igneous rock classification scheme of Streckeisen (1976) is used.

\section{VERNON SUPERSUITE}

\section{BYRAM INTRUSIVE SUITE}

Rocks of the Byram Intrusive Suite are more or less evenly distributed throughout the New Jersey Highlands but are probably most abundant in the Greenwood Lake, Newfoundland, Dover, Mendham, Bernardsville, Gladstone, Califon, Stanhope, Tranquility, and Washington quadrangles. The Byram is variable in texture and ranges from gneissic granite to less distinctly foliated granite and pegmatite. 


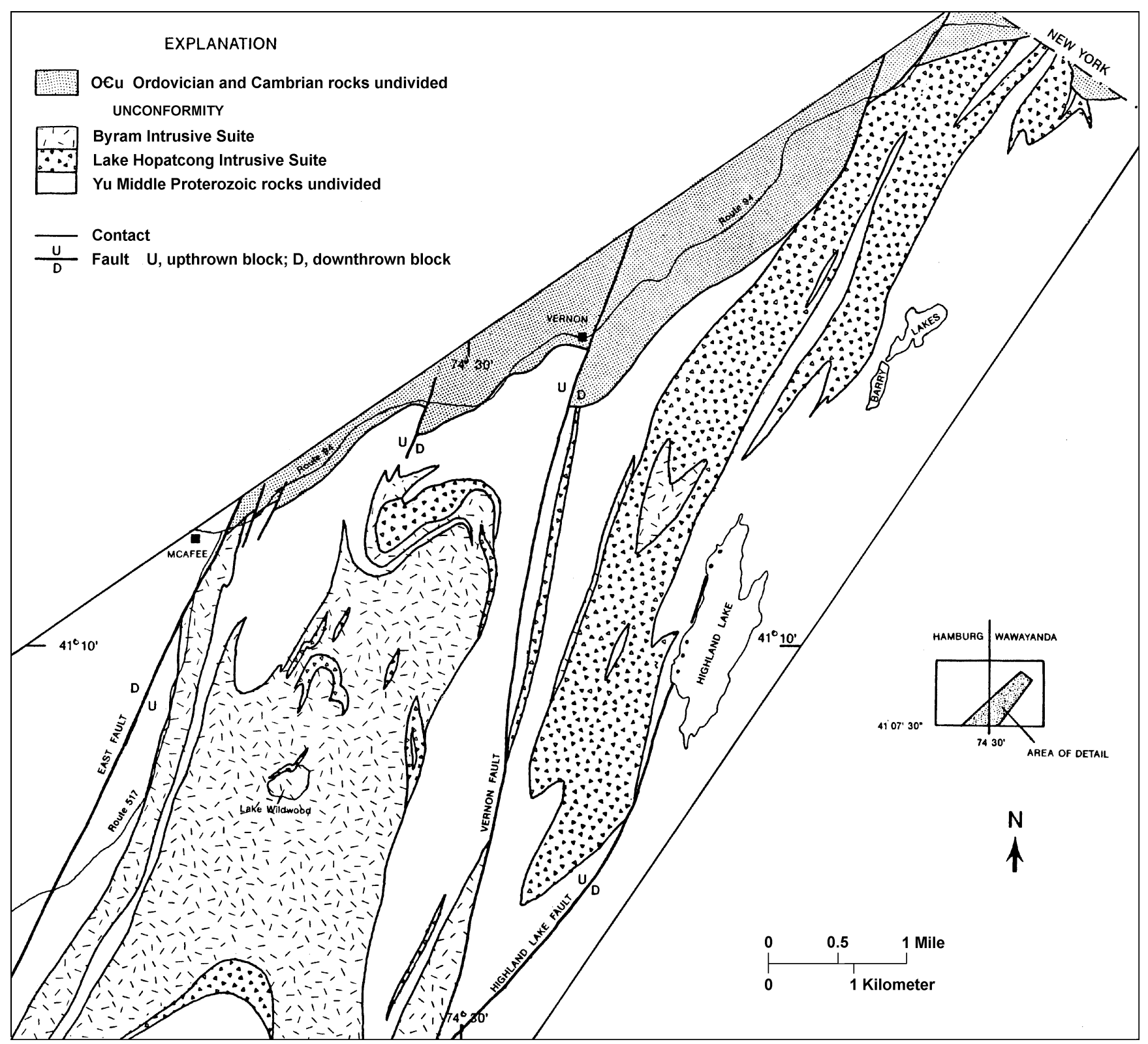

Figure 20. Generalized geologic map of parts of the Hamburg (New Jersey) and Wawayanda (New Jersey-New York) 7.5-min quadrangles showing the distribution of rocks of the Byram and Lake Hopatcong Intrusive Suites in the type area of the Vernon Supersuite. Compiled from R.A. Volkert's unpublished data.

The Byram consists dominantly of hornblende granite (Ybh), biotite granite (Ybb), microperthite alaskite (Yba), and hornblende syenite (Ybs); the hornblende syenite unit also contains hornblende quartz syenite, which was not mapped separately by Drake and others (1996). Other variants have also been recognized. Although they are volumetrically insignificant and are not normally mapped separately, the variants are important for geologic interpretation and merit mention here. Hornblende granite in several areas, most notably the Blairstown quadrangle, contains appreciable biotite in nearly equal proportion to hornblende. Elsewhere, hornblende syenite contains sufficient plagioclase to be termed hornblende monzonite or hornblende quartz monzonite. The monzonitic rocks were noted especially in the Tranquility quadrangle.

Byram rocks are characteristically pinkish gray and medium to coarse grained. They contain hornblende (hastingsite) or biotite as their dominant mafic mineral. The alaskitic variant contains $<5$ percent mafic minerals by definition. Quartz is present in varying amounts, and the feldspars are mainly microperthite and oligoclase. Magnetite is ubiquitous in all phases of the Byram. Sparse amounts of local accessory radioactive minerals are confined to the more differentiated parts of the Byram, namely granite, pegmatite, 
and alaskite. Most phases of the Byram contain small enclaves of amphibolite. However, these are sparse or absent in the biotite-bearing phases.

Hornblende granite from the Greenwood Lake quadrangle has an $\mathrm{U}-\mathrm{Pb}$ upper intercept age of 1,088 $\pm 41 \mathrm{Ma}$ (Drake and others, 1991b). Six samples of hornblende granite from the northern and central Highlands yielded an RbSr whole-rock isochron age of 1,116 $\pm 41 \mathrm{Ma}$ (Volkert and others, unpub. data).

\section{LAKE HOPATCONG INTRUSIVE SUITE}

Rocks of the Lake Hopatcong Intrusive Suite are found throughout the New Jersey Highlands but are primarily west of the Green Pond Mountain region. They are most abundant in the Wawayanda, Franklin, Dover, Stanhope, Hackettstown, and High Bridge quadrangles. These rocks are less variable in texture than the Byram and consist mainly of massive gneissic to less distinctly foliated rocks. Pegmatite is present, usually as small, discrete bodies, but is more sparse than the abundant pegmatite in the Byram Intrusive Suite.

Lake Hopatcong rocks consist dominantly of pyroxene granite (Ypg), pyroxene syenite (Yps), and pyroxene alaskite (Ypa). Pyroxene granite contains three minor phasesgranodiorite, quartz monzodiorite, and monzonite-which were not mapped separately on the new State geologic map (Drake and others, 1996).

Lake Hopatcong Intrusive Suite rocks are characteristically greenish gray to greenish buff and medium to coarse grained. They contain clinopyroxene (hedenbergite) as their dominant mafic mineral. Quartz occurs in varying amounts. The feldspars are mainly mesoperthite or microantiperthite and minor amounts of free oligoclase. Magnetite and titanite are ubiquitous accessory minerals. Amphibolite commonly occurs as small enclaves associated with all variants of the Lake Hopatcong Intrusive Suite.

Six samples of pyroxene granite from the northern and central New Jersey Highlands yielded an Rb-Sr whole-rock isochron age of 1,095 $\pm 9 \mathrm{Ma}$ (Volkert and others, unpub. data).

\section{SIMILARITY OF BYRAM AND LAKE HOPATCONG INTRUSIVE SUITES}

The relationship between the Byram and Lake Hopatcong Intrusive Suites poses another dilemma in interpreting rock relations in the New Jersey Highlands. Crosscutting relationships and chilled margins are absent between rocks of these two suites, and all contacts appear to be conformable. Where Byram and Lake Hopatcong rocks are in contact, a hybrid border phase containing both amphibole and clinopyroxene was locally observed. In terms of their respective mineralogy, Byram and Lake
Hopatcong rocks define two distinct suites. Despite this difference, it is now clear that striking similarities exist in their chemistry. In order to characterize the overall composition of these rocks and compare them with granites from various tectonic settings, major- and trace-element data were obtained from both suites throughout the Highlands, the results of which were summarized by Volkert (1995).

Byram (table 14) and Lake Hopatcong (table 15) rocks overlap in nearly all contents of major oxides and normative mineralogy (fig. 21). However, Lake Hopatcong rocks contain slightly more $\mathrm{Fe}_{2} \mathrm{O}_{3}$ and $\mathrm{Na}_{2} \mathrm{O}$ and slightly less $\mathrm{MgO}$, $\mathrm{CaO}$, and $\mathrm{K}_{2} \mathrm{O}$. Trace-element concentrations also overlap, although $\mathrm{Ba}, \mathrm{Rb}, \mathrm{Sr}, \mathrm{U}$, and $\mathrm{Th}$ tend to be slightly more abundant in Byram rocks. Both suites are moderately enriched in $\mathrm{Y}, \mathrm{Nb}$, and $\mathrm{Zr}$. On the alumina/alkali index diagram of $\mathrm{Al}_{2} \mathrm{O}_{3} /\left(\mathrm{Na}_{2} \mathrm{O}+\mathrm{K}_{2} \mathrm{O}\right)$ versus $\mathrm{Al}_{2} \mathrm{O}_{3} /\left(\mathrm{CaO}+\mathrm{Na}_{2} \mathrm{O}+\right.$ $\mathrm{K}_{2} \mathrm{O}$ ) (fig. 22), all of the Lake Hopatcong and most of the Byram samples are metaluminous. A few Byram samples are marginally peraluminous.

Byram and Lake Hopatcong rocks fall within the A-type granite compositional field (fig. 23). As defined by Collins and others (1982), White and Chappell (1983), and Whalen and others (1987), A-type granite characteristically has low contents of $\mathrm{Al}_{2} \mathrm{O}_{3}, \mathrm{MgO}$, and $\mathrm{CaO}$ and high contents of $\mathrm{SiO}_{2}, \mathrm{Na}_{2} \mathrm{O}+\mathrm{K}_{2} \mathrm{O}, \mathrm{Nb}, \mathrm{Zr}, \mathrm{Y}$, and light rare-earth elements (REE's). High $\mathrm{Nb}, \mathrm{Zr}, \mathrm{Y}$, and REE contents are diagnostic of A-type granite and help to distinguish it from compositionally similar I-type granite. A-type magma also typically contains fluorine (Collins and others, 1982; Whalen and others, 1987). Sparse amounts of fluorite occur in Byram rocks in the Hamburg, Pompton Plains, Wanaque, and Franklin quadrangles. Hotz (1953) reported its occurrence in Byram rocks in the Sterling Lake, N.Y., area.

The A-type granite geochemical signature was previously interpreted to mean that such rocks were post-tectonic and anorogenic and had intruded in a within-plate, extensional tectonic setting. This interpretation is inconsistent with the known geologic relations in the Highlands that suggest Byram and Lake Hopatcong rocks are synorogenic and were emplaced during a compressional tectonic regime. More recent work involving A-type granite (for example, Whalen and others, 1987; Sylvester, 1989; and Whalen and Currie, 1990) shows that it can be generated in a variety of tectonic environments unrelated to anorogenic rifting. These environments may include subduction zones.

As stated, Byram and Lake Hopatcong rocks consistently have few discernible differences on plots of various major- and trace-element combinations. Their chemical similarity leads inescapably to the question of whether these rocks actually define two distinct and separate intrusive suites. Recent geochemical work (Volkert, 1995) suggests that they do not and permits the following simplified interpretation from Volkert (1993). Partial melting of relatively anhydrous lower crustal source rocks 

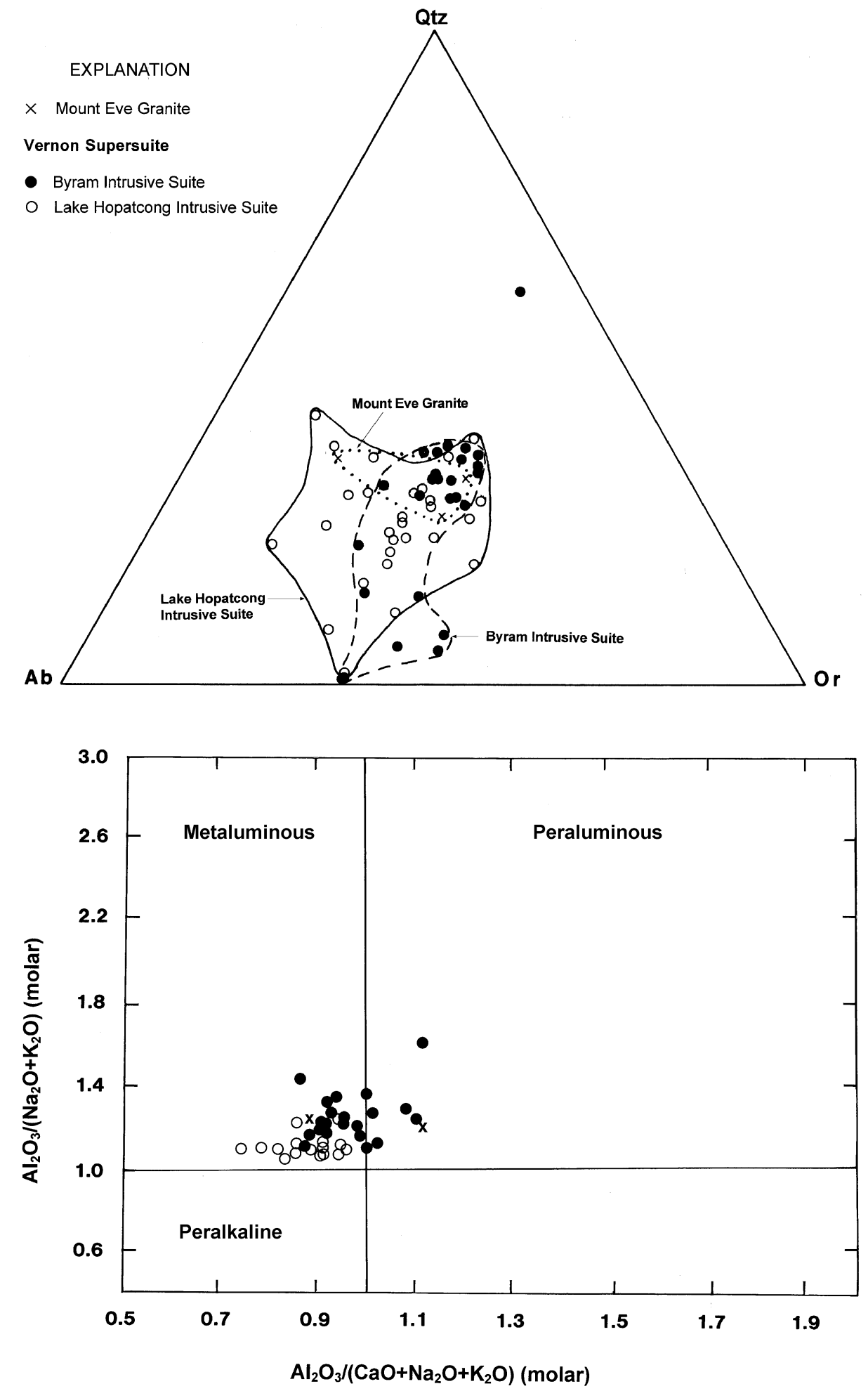

Figure 21. Normative quartzorthoclase-albite plot of Vernon Supersuite rocks and the Mount Eve Granite in the New Jersey Highlands. Geochemical data for the samples plotted are in tables 14-16.

Figure 22. Alumina/alkali index diagram (Shand, 1949) showing chemical classification of granitic rocks in the New Jersey Highlands. Symbols as in figure 21. Representative samples from tables $14-16$ are plotted; some samples are omitted for clarity.

of felsic composition generated magma that was mainly alkaline (fig. 24) and metaluminous (fig. 22). Hypersolvus Lake Hopatcong rocks were the first to crystallize from this magma under what Young (1972) and Rhett (1975) proposed were conditions of low water pressure and high temperature. Young (1972) estimated that the temperature was well in excess of $800^{\circ} \mathrm{C}$ at the time of intrusion, whereas Rhett (1975) estimated the temperature to have been closer to $770^{\circ} \mathrm{C}$. The anhydrous conditions under which the Lake Hopatcong rocks formed favored the development of clinopyroxene and suppressed the formation of pegmatites, which are sparse in Lake Hopatcong rocks. As the melt became more hydrous in response to decreased temperature and pressure, amphibole formed at the expense 


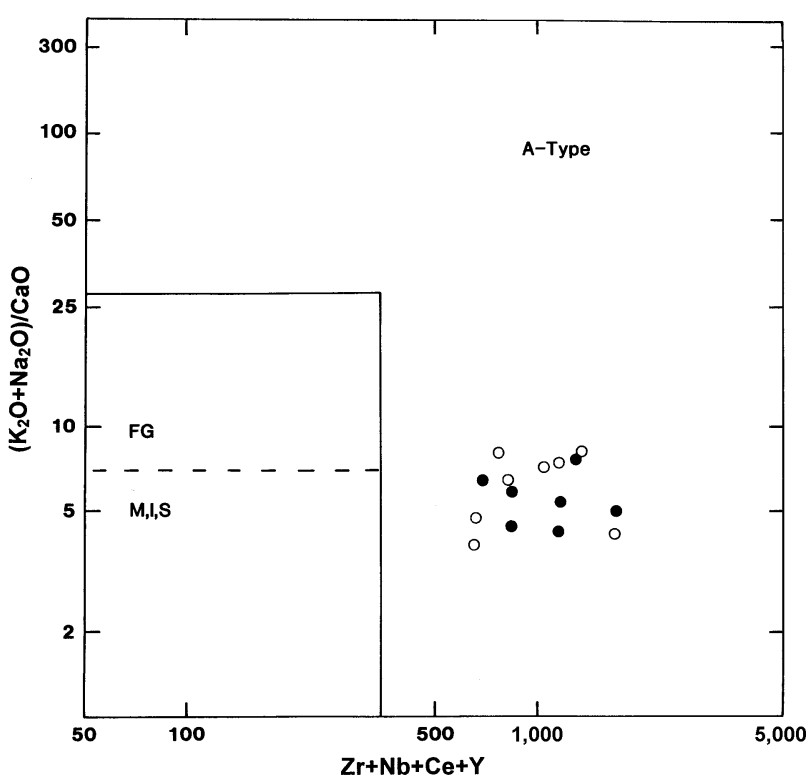

Figure 23. $\left(\mathrm{K}_{2} \mathrm{O}+\mathrm{Na}_{2} \mathrm{O}\right) / \mathrm{CaO}$ versus $\mathrm{Zr}+\mathrm{Nb}+\mathrm{Ce}+\mathrm{Y}$ discrimination diagram (Whalen and others, 1987) of granitic rocks in the New Jersey Highlands. Note overlap of rocks from the Byram and Lake Hopatcong Intrusive Suites and their restriction to A-type granite field. Other fields are for fractionated granite (FG) and M-, I-, and S-type granites. Symbols as in figure 21. Data on Ce from Volkert (1995); other data from tables 14 and 15.

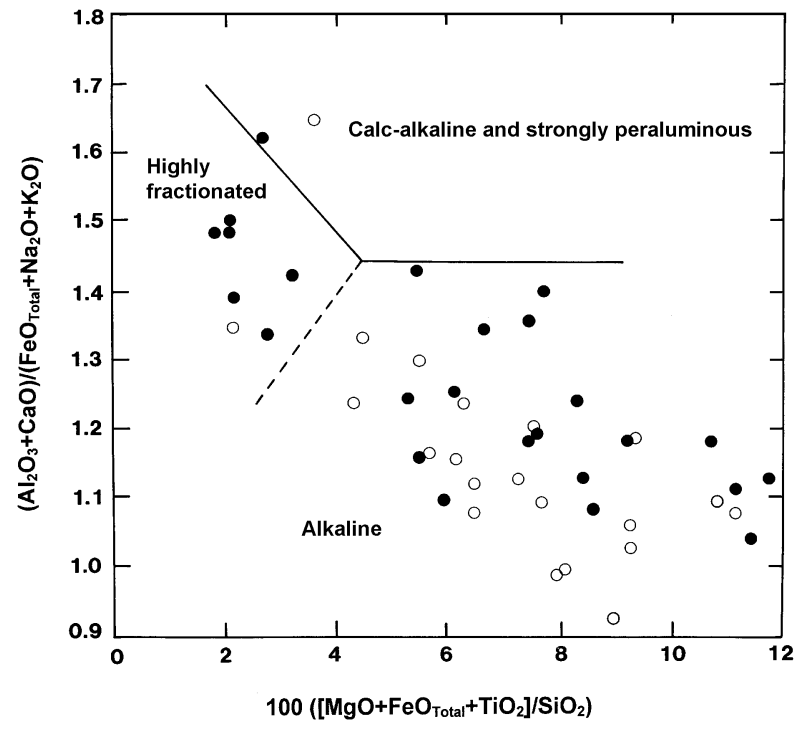

Figure 24. Major-element discrimination diagram (Sylvester, 1989) of granitic rocks in the New Jersey Highlands showing plot of Byram and Lake Hopatcong Intrusive Suites. $\mathrm{FeO}_{\text {Total }}$ indicates that all $\mathrm{Fe}$ is reported as FeO. Symbols as in figure 21.

of clinopyroxene, and the mesoperthitic to microantiperthitic feldspars unmixed to form microperthite and free plagioclase characteristic of subsolvus Byram rocks. The principal differences between the Byram and Lake
Hopatcong rocks are in the mineralogy and the slightly more evolved composition of the Byram.

Following this scheme, Volkert (1993) interpreted the Byram and Lake Hopatcong rocks to be cogenetic and comagmatic. This interpretation is supported by the field relationships, as well as the geochemical and geochronological data. Therefore, rocks of the Byram and Lake Hopatcong Intrusive Suites are formally recognized as suites within the Vernon Supersuite.

\section{MOUNT EVE GRANITE}

Rocks mapped as Mount Eve Granite (Ygm) occur in the extreme northern Highlands (fig. 19), where they straddle the New Jersey-New York border. In New Jersey they are confined to the Pine Island, Unionville, Wawayanda, and Hamburg quadrangles. The rocks are homogeneous, moderately to indistinctly foliated granite that are light gray to pinkish gray and medium to coarse grained. The Mount Eve contains biotite and subordinate hornblende as mafic minerals. Quartz is generally, but not everywhere, an important constituent. The feldspars are microperthite and oligoclase. Common accessory minerals include magnetite and allanite. Alaskite and very local pegmatite are variants of the Mount Eve Granite.

The Mount Eve is clearly a late synorogenic to postorogenic granite. Geologic mapping by the authors in the Hamburg, Wawayanda, Unionville, and Pine Island quadrangles shows that the Mount Eve is discordant to lithologic contacts in adjacent units, contains inclusions of local metasedimentary rock, and has produced contact aureoles where intrusive into the Franklin Marble.

Limited chemical data pertaining to the Mount Eve Granite (table 16) show ranges of major oxides that overlap those of rocks in both the Byram and Lake Hopatcong Intrusive Suites. As defined by the two samples in figure 22, the Mount Eve is metaluminous to marginally peraluminous.

Mount Eve Granite from the Pine Island quadrangle has a U-Pb upper intercept age of 1,020 $\pm 4 \mathrm{Ma}$ (Drake and others, 1991a). Mount Eve pegmatite from the same location has a U-Pb upper intercept age of $1,004 \pm 3$ Ma (P.B. Moore, oral commun., 1993).

\section{OTHER ROCKS}

\section{AMPHIBOLITES}

The name Pochuck Gneiss was introduced by Spencer and others (1908) for all dark-colored gneiss containing hornblende, clinopyroxene, and biotite that is exposed on Pochuck Mountain in the Hamburg and Wawayanda quadrangles. The name Pochuck Gneiss was used on the old State geologic map (Lewis and Kümmel, 1912) for amphibolite in these two quadrangles, but we choose not to use it 
because the rocks classified as Pochuck are neither lithologically nor stratigraphically distinctive.

Rocks mapped as amphibolite (Ya) are widespread throughout the New Jersey Highlands, where they occur in virtually every quadrangle. They are associated with nearly all other Middle Proterozoic rocks. Amphibolite is a grayish-black, medium-grained, moderately foliated rock that contains hornblende and plagioclase (andesine). Some types interlayered with calcareous metasedimentary rocks contain clinopyroxene, and some interlayered with quartzofeldspathic gneiss contain biotite. Hypersthene is a local accessory where amphibolite is associated with charnockitic rocks. Magnetite is a ubiquitous accessory in practically all phases of amphibolite.

In the southwestern Highlands, some amphibolite is locally migmatized by veins and layers of quartz and feldspar (potassium feldspar or plagioclase). Migmatitic amphibolite (Yam) in this part of the Highlands was described by Drake $(1969,1984)$. Migmatitic amphibolite is less common in the central and northern Highlands. One sample in table 17 (no. 22) is a paleosome near a contact with microperthite alaskite from the central Highlands.

Amphibolite was mapped as a single unit in the New Jersey Highlands. Because it was easily identified during mapping, and because an exhaustive analysis of amphibolites was not deemed critical, this unit was not studied in as much detail as some of the other rocks. Regardless, it is clear from the field relationships and from our limited geochemical data that amphibolite in the Highlands has at least four different protoliths as discussed below.
Metasedimentary amphibolite.-Drake (1984) interpreted much of the amphibolite in the southwestern Highlands to be metasedimentary, originally calcareous shale, because it is conformably interlayered with calc-silicate gneiss and marble. Volkert has recognized and mapped only minor amounts of metasedimentary amphibolite in the central and northern Highlands. It is characteristically rusty, punky weathering, biotitic, and sulfidic. The protolith likely was a calcareous shale also.

Metavolcanic amphibolite.-The predominant type of amphibolite in the central and northern New Jersey Highlands is metavolcanic. Geochemical analyses of amphibolites in table 17 suggest that all are probably metavolcanic in origin. Several of these have the composition of tholeiitic basalt from a midocean ridge or back arc basin setting. Sample 211, associated with rocks of the Losee Metamorphic Suite, also is tholeiitic but has an affinity toward an origin in an island arc environment (fig. 25). Samples B29 and 168, associated with calc-silicate gneiss and marble, are alkalic basalt and fall mainly in a within-plate field on various tectonic discrimination diagrams (for example, fig. 25). Hague and others (1956) identified pillow structures in amphibolite from Sussex County. One of the pillow localities associated with arkosic quartzofeldspathic gneiss and marble was illustrated by Drake (1990); a geochemical study by Volkert (Volkert and others, 1986) on a sample (table 17, no. 48) from the illustrated locality showed the protolith to be a tholeiitic basalt closely resembling basalt from a midocean ridge setting. Maxey (1971) chemically analyzed 56 samples of northern Highlands amphibolites and concluded, on

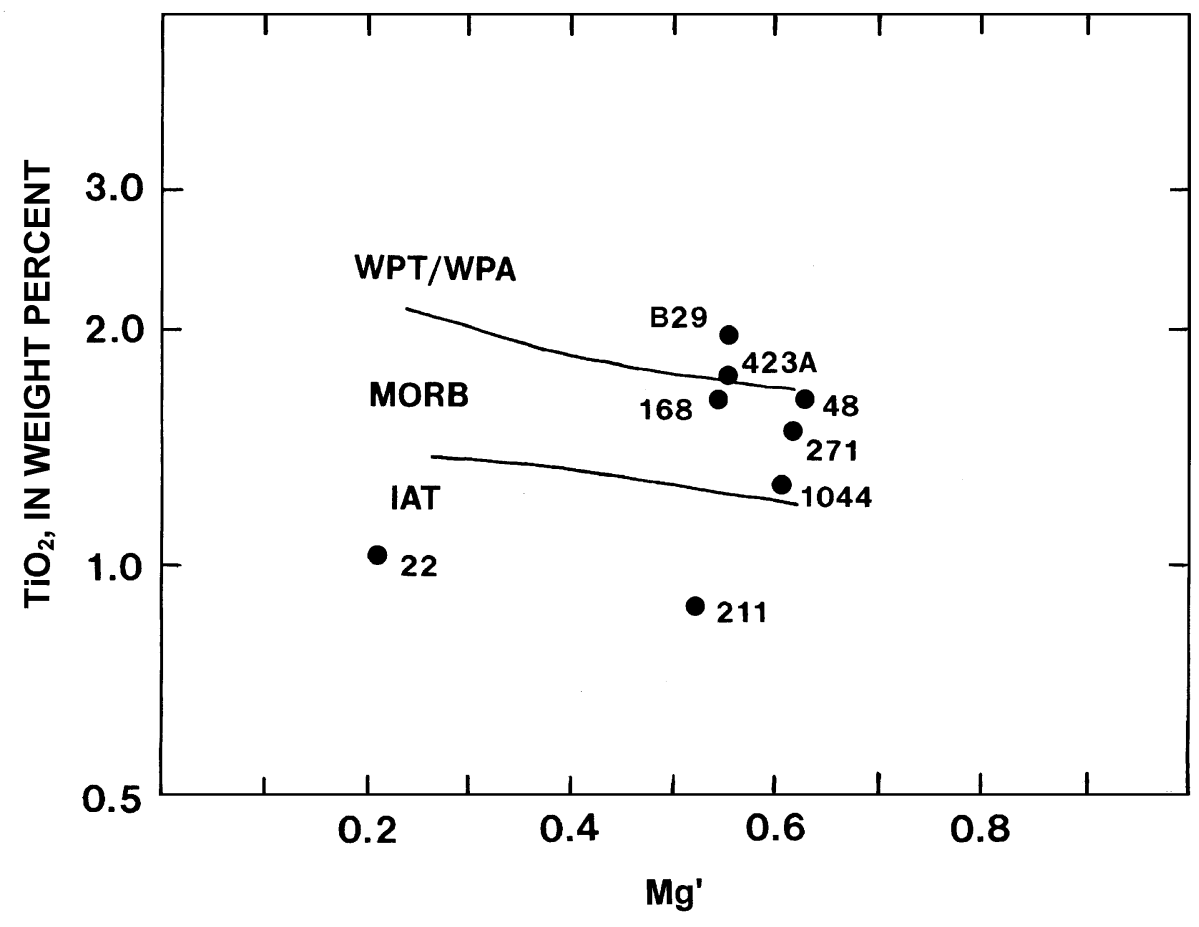

Figure 25. $\log \mathrm{TiO}_{2}$ versus $\mathrm{Mg}^{\prime}$ plot (Basaltic Volcanism Study Project, 1981) of amphibolites in the New Jersey Highlands. Mg'= $100 \quad\left(\mathrm{Mg} /\left[\mathrm{Mg}+\mathrm{Fe}^{2+}\right]\right) . \quad$ Fields: WPT/WPA, within-plate tholeiitic/ alkalic; MORB, midocean ridge basalt; IAT, island arc tholeiite. Geochemical data for the samples plotted are in table 17. 
the basis of major- and trace-element compositions, that all were metabasalt.

Metagabbroic amphibolite.-Still other amphibolite appears to be metagabbro. Baker and Buddington (1970) described amphibolite from the Franklin quadrangle with a locally preserved relict primary igneous texture. Hull and others (1986) identified a similar occurrence in the Tranquility quadrangle. The field association of these rocks is masked by the large volume of intrusive rocks that surrounds them.

Metaporphyric amphibolite.-A fourth, very distinctive type of amphibolite is a metaporphyry containing rectangular phenocrysts of plagioclase as much as an inch or more in length in a matrix of medium-grained hornblende and plagioclase. This type of amphibolite was recognized by Volkert in exposures of limited areal extent in the Stanhope, Tranquility, and Blairstown quadrangles. A similar exposure was identified recently in the Easton quadrangle (D.H. Monteverde, New Jersey Geological Survey, oral commun., 1993). In the Blairstown quadrangle, this rock type is completely enclosed in a large body of biotite-hornblende granite. In the Tranquility quadrangle, it is intimately interlayered with layered charnockitic gneiss and grades along strike into biotite amphibolite. In the Easton and Stanhope quadrangles, it appears to be spatially associated with Losee Metamorphic Suite rocks, but the stratigraphic relations in Stanhope are masked by exposures of intrusive rocks. It is likely that this type of amphibolite is metavolcanic because of its known lithologic associations and a geochemical analysis of the rock from Tranquility (table 17, sample 423A), which is tholeiitic basalt with a composition that could indicate either a midocean ridge or a within-plate tectonic setting (fig. 25).

Because amphibolite is derived from different protoliths, it logically follows that not all amphibolite in the New Jersey Highlands has the same age. That associated with the Losee Metamorphic Suite (including its charnockitic rocks) is obviously the oldest. It very likely was metabasalt, although some may well have been metagabbro. Amphibolite interlayered with metasedimentary rocks may be older than amphibolite associated with Vernon Supersuite intrusive rocks.

\section{BIOTITE-PLAGIOCLASE GNEISS}

Rocks mapped as biotite-plagioclase gneiss (Ybp), though sparsely exposed in the New Jersey Highlands, are geologically significant. They appear to be of two main types. The first is dark-gray, medium-grained biotite-plagioclase gneiss containing hornblende, magnetite, and sparse amounts of clinopyroxene. With increases in quartz and biotite, this rock appears to grade into biotite-quartz-plagioclase gneiss with local accessory hornblende of the Losee Metamorphic Suite and, with an increase in hornblende, it grades into biotite amphibolite. Sample 195 (table 18) is a good example. It is also spatially associated with quartz-oligoclase gneiss, as is sample 223 (table 18) from the Hamburg quadrangle. Both have the composition of tholeiitic basaltic andesite. Sample 1037 (table 18) from the Newton East quadrangle is composed of plagioclase, hornblende, subordinate biotite, and trace amounts of magnetite and apatite. This rock grades from biotite amphibolite with increases in biotite and quartz into biotite-quartz-plagioclase gneiss of the Losee Metamorphic Suite that is seamed by albite-oligoclase granite (Volkert and others, 1986). It differs from other biotite-plagioclase gneiss in having a more undersaturated, olivine- and nepheline-normative composition that is higher in total iron. Chemically, this rock may have been an alkali olivine basalt, or picrite, that formed a thin sill.

The second type of biotite-plagioclase gneiss was mapped by Young (1969). It appears to be confined to the Dover quadrangle. It is a gray, foliated rock composed of plagioclase (andesine), biotite, hornblende, clinopyroxene, and magnetite and local apatite, garnet, and titanite. This unit contains a thin mafic layer composed mainly of plagioclase (labradorite to andesine), hornblende, clinopyroxene, orthopyroxene, and magnetite; locally, it contains biotite and apatite. This type of biotite-plagioclase gneiss is spatially associated with rocks of the Lake Hopatcong Intrusive Suite and metasedimentary gneisses. It contains no modal quartz, nor does it grade into rocks containing quartz. The chemistry of this unit led Young and Icenhower (1989) to interpret it as a metamorphosed sill of anorthosite and mafic layered gabbroic anorthosite. Despite the mineralogical similarity with the first type of biotite-plagioclase gneiss described here, it clearly is a different rock in that it has $>20$ weight percent $\mathrm{Al}_{2} \mathrm{O}_{3}$, a higher $\mathrm{Na}_{2} \mathrm{O}$ content, and much lower $\mathrm{FeO}$ and $\mathrm{MgO}$ contents (table 18). Trace-element abundances are comparable to those in the first type of biotite-plagioclase gneiss. This unit is especially significant as no other rocks of anorthositic composition have thus far been recognized in the New Jersey Highlands.

\section{PROTEROZOIC TECTONIC HISTORY OF THE HIGHLANDS-A SYNTHESIS}

A simplified version of rock relations in the New Jersey Highlands is shown schematically in figure 26. If rocks of the Losee Metamorphic Suite (including its charnockitic rocks) are the oldest exposed rocks in the Highlands, then they record an early episode of compressional tectonism at about 1,350 to 1,300 Ma resulting from the subduction of an oceanic crustal slab beneath the Middle Proterozoic continental margin. Partial melting of the subducting slab could have generated a series of continental magmatic arcs similar to the present Andes Mountains. Magmatism at this time was mainly calc-alkaline to tholeiitic in composition. Final 


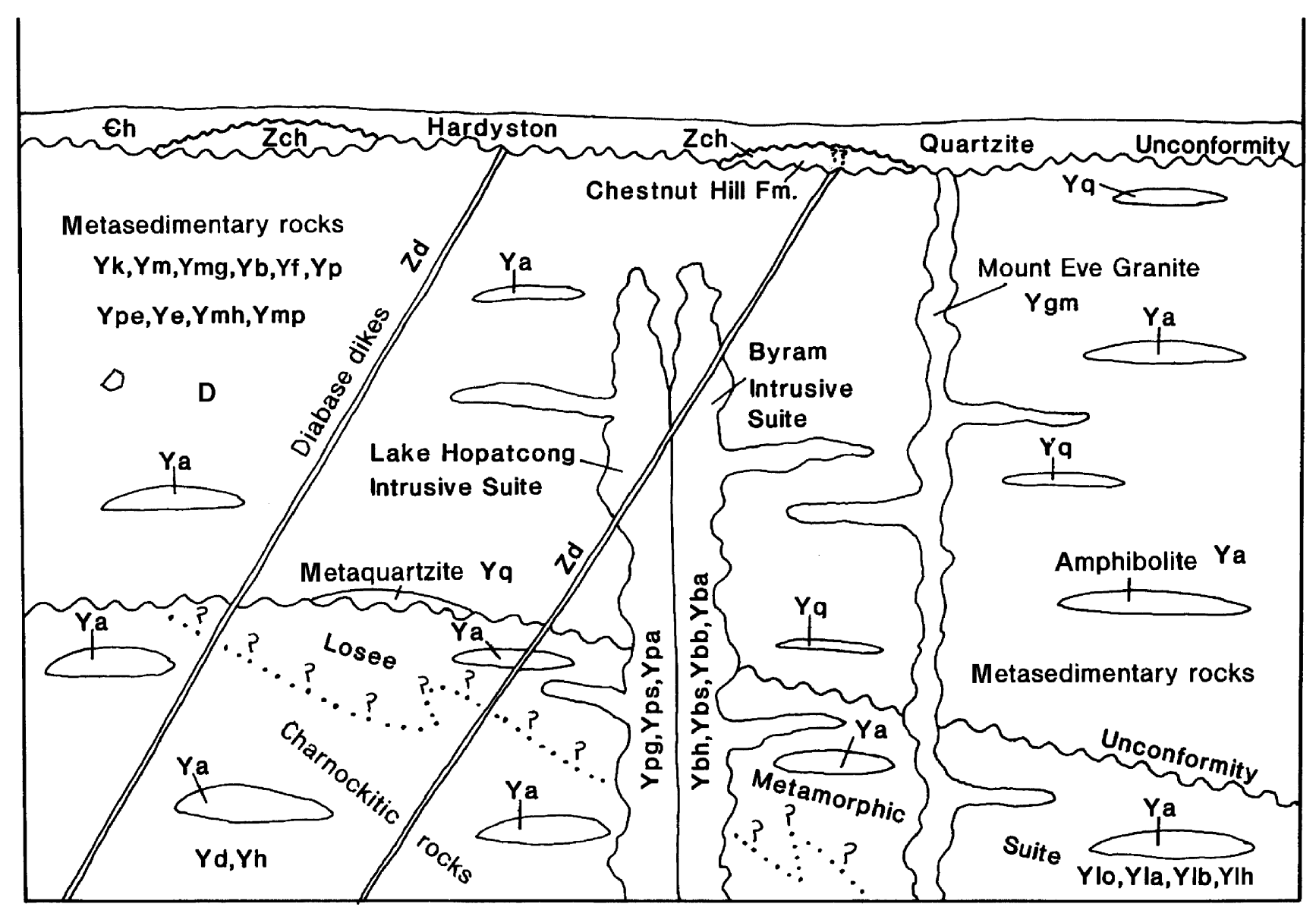

Figure 26. Schematic diagram showing inferred stratigraphic relations of major Middle Proterozoic and Late Proterozoic rocks in the New Jersey Highlands. Dotted line separates leucocratic and charnockitic rocks of the Losee Metamorphic Suite.

suturing of the oceanic and continental plates occurred sometime after 1,300 Ma and produced an uplifted continental block.

Sometime after 1,300 Ma, a period of quiescence and erosion of the continental terrane occurred until about 1,100 Ma. Sedimentation may have occurred in a cratonic basin setting with the deposition of the quartzose sandstone and arkosic sediments that now are metaquartzite and potassium-feldspar gneiss, microcline gneiss, and monazite gneiss. A subsequent change in the composition of material shed from the source areas led to an increase in the amount of lithic fragments over feldspar and deposition of the lithic arenites. Perhaps this marked a transition from sedimentation in a largely terrestrial environment to sedimentation in a shallow-marine site. Continued erosion of the continental source and the onset of an extensional tectonic regime resulted in marine transgression. This transgression led to the deposition in a marine basin of a mixed sequence of quartzose sandstone, calcareous rocks, limestone, and graywacke. Some sedimentation was probably associated with tholeiitic basalt from a small spreading center in this basin. The presence of a spreading center is consistent with the close spatial association of amphibolite containing relict pillow structures and marble along the eastern margin of Pochuck Mountain and elsewhere in the Highlands and also with the association of amphibolite representing basalt of MORB (midocean ridge basalt) affinity with pyroxene gneiss and biotite-quartz-feldspar gneiss.

Sedimentation was interrupted by the eventual destruction of the basin during the onset of compressional tectonism that began at about 1,100 Ma and lasted until 1,000 Ma. The onset of compression likely was marked by the development of an oceanic island arc. During the interval between about 1,100 $\mathrm{Ma}$ and about 1,090 Ma, A-type magma of dominantly alkaline, metaluminous composition was generated, and the granites and related rocks of the Lake Hopatcong and Byram Intrusive Suites were emplaced. The emplacement was followed by the full intensity of the Grenville orogenesis, during which all Middle Proterozoic rocks of the New Jersey Highlands were metamorphosed to upper amphibolite to hornblende-granulite facies. The Mount Eve Granite was emplaced during the waning stages of Grenville orogenesis at about 1,020 Ma, and some late pegmatites were intruded. 


\section{EXPLANATION}

\begin{tabular}{|c|c|c|}
\hline \multicolumn{3}{|c|}{ Post-Grenville Orogeny Rocks } \\
\hline Eh & \multicolumn{2}{|c|}{ Hardyston Quartzite } \\
\hline Zch & \multicolumn{2}{|c|}{ Chestnut Hill Formation } \\
\hline & \multicolumn{2}{|c|}{ Metasedimentary Rocks (Supracrustal Rocks) } \\
\hline Yk & \multicolumn{2}{|c|}{ Potassium-feldspar gneiss } \\
\hline Ym & \multicolumn{2}{|c|}{ Microcline gneiss } \\
\hline Ymg & \multicolumn{2}{|c|}{ Monazite gneiss } \\
\hline $\mathrm{Yb}$ & \multicolumn{2}{|c|}{ Biotite-quartz-feldspar gneiss } \\
\hline Ymh & \multicolumn{2}{|c|}{ Hornblende-quartz-feldspar gneiss } \\
\hline Ymp & \multicolumn{2}{|c|}{ Clinopyroxene-quartz-feldspar gneiss } \\
\hline Yp & \multicolumn{2}{|c|}{ Pyroxene gneiss } \\
\hline Ype & \multicolumn{2}{|c|}{ Pyroxene-epidote gneiss } \\
\hline Ye & \multicolumn{2}{|c|}{ Quartz-epidote gneiss } \\
\hline Ya & \multicolumn{2}{|c|}{ Amphibolite } \\
\hline Yq & \multicolumn{2}{|c|}{ Metaquartzite } \\
\hline Yf & \multicolumn{2}{|c|}{ Franklin Marble } \\
\hline & \multicolumn{2}{|c|}{ Losee Metamorphic Suite (Basement Rocks) } \\
\hline \multicolumn{3}{|c|}{ Dacitic, Tonalitic, and Trondhjemitic Rocks } \\
\hline & Ylo & Quartz-oligoclase gneiss \\
\hline & Yla & Albite-oligoclase granite \\
\hline & $\mathrm{Ylb}$ & Biotite-quartz-oligoclase gneiss \\
\hline & Ylh & Hornblende-quartz-oligoclase gneiss \\
\hline & Ya & Amphibolite \\
\hline \multicolumn{3}{|c|}{ Charnockitic Rocks } \\
\hline & Yd & Diorite \\
\hline & $\mathrm{Yh}$ & Hypersthene-quartz-plagioclase gneis \\
\hline & Ya & Amphibolite \\
\hline
\end{tabular}

\begin{tabular}{|c|c|c|}
\hline \multicolumn{3}{|c|}{ Intrusive Rocks } \\
\hline $\mathrm{Zd}$ & \multicolumn{2}{|c|}{ Diabase dikes } \\
\hline Ygm & \multicolumn{2}{|c|}{ Mount Eve Granite } \\
\hline \multicolumn{3}{|c|}{$\begin{array}{l}\text { Vernon Supersuite } \\
\quad \text { Byram Intrusive Suite }\end{array}$} \\
\hline & bh & Hornblende granite \\
\hline & bs & Hornblende syenite \\
\hline & bb & Biotite granite \\
\hline & ba & Microperthite alaskite \\
\hline
\end{tabular}

Lake Hopatcong Intrusive Suite Ypg Pyroxene granite

Yps Pyroxene syenite

Ypa Pyroxene alaskite

Figure 26. Continued.

Between about 1,000 Ma and $760 \mathrm{Ma}$, another period of quiescence occurred. This was followed at about $760 \mathrm{Ma}$ by the onset of extensional tectonism and rifting of the proto-North American continent. Continental rift basins were the setting for the deposition of the Late Proterozoic Chestnut Hill Formation (Zch) (Drake, 1984), a weakly metamorphosed sequence of interbedded clastic and metavolcanic rocks and metasaprolite. These rocks are currently very locally preserved as erosional remnants and as small slices along faults mainly in the southwest Highlands. Continued rifting produced fractures in the crust that acted as conduits, allowing diabase dikes of Late Proterozoic age (Puffer and others, 1991; Volkert and Puffer, 1995) to intrude Middle Proterozoic rocks throughout the Highlands. Cessation of Late Proterozoic sedimentation and magmatism in the Highlands was followed by further quiescence, erosion, and deposition of the Hardyston Quartzite (Eh) during the Early Cambrian.

\section{REFERENCES CITED}

Aleinikoff, J.N., Ratcliffe, N.M., Burton, W.C., and Karabinos, P., 1990, U-Pb ages of Middle Proterozoic igneous and metamorphic events, Green Mountains, Vermont [abs.]: Geological Society of America Abstracts with Programs, v. 22, p. 1.

Bailey, J.C., 1981, Geochemical criteria for a refined tectonic discrimination of orogenic andesites: Chemical Geology, v. 32, p. 139-154.

Baker, D.R., and Buddington, A.F., 1970, Geology and magnetite deposits of the Franklin quadrangle and part of the Hamburg quadrangle, New Jersey: U.S. Geological Survey Professional Paper 638, $73 \mathrm{p}$.

Basaltic Volcanism Study Project, 1981, Basaltic volcanism on the terrestrial planets: New York, Pergamon Press, 1286 p.

Bhatia, M.R., 1983, Plate tectonics and geochemical compositions of sandstones: Journal of Geology, v. 91, p. 611-627.

Blatt, Harvey, Middleton, Gerard, and Murray, Raymond, 1972, Origin of sedimentary rocks: Englewood Cliffs, N.J., Prentice-Hall, Inc., 634 p.

Collins, W.J., Beams, S.D., White, A.J.R., and Chappell, B.W., 1982, Nature and origin of A-type granites with particular reference to southeastern Australia: Contributions to Mineralogy and Petrology, v. 80, p. 189-200.

Drake, A.A., Jr., 1969, Precambrian and lower Paleozoic geology of the Delaware Valley, New Jersey-Pennsylvania, in Subitzky, Seymour, ed., Geology of selected areas in New Jersey and eastern Pennsylvania and guidebook of excursions: New Brunswick, N.J., Rutgers University Press, p. 51-131. 
1984, The Reading Prong of New Jersey and eastern Pennsylvania: An appraisal of rock relations and chemistry of a major Proterozoic terrane in the Appalachians, in Bartholomew, M.J., ed., The Grenville event in the Appalachians and related topics: Geological Society of America Special Paper 194, p. 75-109.

1990, The regional geologic setting of the Franklin-Sterling Hill district, Sussex County, New Jersey, in Character and origin of the Franklin-Sterling Hill ore-bodies: Bethlehem, Pennsylvania, Lehigh University-Franklin-Ogdensburg Mineralogical Society Symposium proceedings volume, $\mathrm{p}$. 14-31.

Drake, A.A., Jr., Aleinikoff, J.N., and Volkert, R.A., 1991a, The Mount Eve Granite (Middle Proterozoic) of northern New Jersey and southeastern New York, chap. C of Drake, A.A., Jr., ed., Contributions to New Jersey geology: U.S. Geological Survey Bulletin 1952, p. C1-C10.

1991b, The Byram Intrusive Suite of the Reading Prong-Age and tectonic environment, chap. D of Drake, A.A., Jr., ed., Contributions to New Jersey geology: U.S. Geological Survey Bulletin 1952, p. D1-D14.

Drake, A.A., Jr., and Volkert, R.A., 1991, The Lake Hopatcong Intrusive Suite (Middle Proterozoic) of the New Jersey Highlands, chap. A of Drake, A.A., Jr., ed., Contributions to New Jersey geology: U.S. Geological Survey Bulletin 1952, p. A1-A9.

Drake, A.A., Jr., Volkert, R.A., Monteverde, D.H., Herman, G.C., Houghton, H.F., Parker, R.A., and Dalton, R.F., 1996, Bedrock geologic map of New Jersey: U.S. Geological Survey Miscellaneous Investigations Series Map I-2540-A, 2 sheets, scale $1: 100,000$.

Garrels, R.M., and McKenzie, F.T., 1971, Evolution of sedimentary rocks: New York, Norton, $397 \mathrm{p}$.

Hague, J.M., Baum, J.L., Hermann, L.A., and Pickering, R.J., 1956, Geology and structure of the Franklin-Sterling area, New Jersey: Geological Society of America Bulletin, v. 67, p. 435-474.

Hotz, P.E., 1953, Magnetite deposits of the Sterling Lake, N.Y.-Ringwood, N.J. area: U.S. Geological Survey Bulletin 982-F, p. 153-244.

Houghton, H.F., and Volkert, R.A., 1990, Bedrock geologic map of the Gladstone quadrangle, Morris, Hunterdon, and Somerset Counties, New Jersey: New Jersey Geological Survey Geologic Map Series GMS 89-4, scale 1:24,000.

Hull, J.M., Koto, R.Y., and Bizub, R., 1986, Deformation zones in the Highlands of New Jersey, in Husch, J.M., and Goldstein, F.R., eds., Geology of the New Jersey Highlands and radon in New Jersey: Field guide and proceedings of the third annual meeting of the Geological Association of New Jersey, p. 1966.

Irvine, T.N., and Baragar, W.R.A., 1971, A guide to the chemical classification of the common volcanic rocks: Canadian Journal of Earth Sciences, v. 8, p. 523-543.

Jackson, L.L., Brown, F.W., and Neil, S.T., 1987, Major and minor elements requiring individual determination, classical whole rock analysis, and rapid rock analysis, chap. $\mathrm{G}$ of Baedecker, P.A., ed., Methods for geochemical analysis: U.S. Geological Survey Bulletin 1770, p. G1-G23.
Jakes, P., and White, A.J.R., 1972, Major and trace element abundances in volcanic rocks of orogenic areas: Geological Society of America Bulletin, v. 83, p. 29-40.

Kastelic, R.L., Jr., 1979, Precambrian geology and magnetite deposits of the New Jersey Highlands in Warren County, New Jersey: Bethlehem, Pa., Lehigh University, unpublished M.S. thesis, $148 \mathrm{p}$.

Kay, S.M., Ramos, V.A., and Kay, R.W., 1984, Elementos mayoritarios y trazas de las vulcanitas ordovicicas de la Precordillera Occidental: Basaltos de rift oceánico temprano próximas al margin continental, in Actas 9th Congreso Geológico Argentino, Bariloche, v. 8, p. 48-65.

LeBas, M.J., LeMaitre, R.W., Streckeisen, A., and Zanettin, B., 1986, A chemical classification of volcanic rocks based on the total alkali-silica diagram: Journal of Petrology, v. 27, p. 745750 .

Lewis, J.L., and Kümmel, H.B., 1912, Geologic map of New Jersey: New Jersey Department of Conservation and Development, Atlas Sheet no. 40, scale 1:250,000.

Markewicz, F.J., ca. 1965, Chester monazite belt: Unpublished report on file in the office of the New Jersey Geological Survey, Trenton, N.J., 6 p.

Maxey, L.R., 1971, Metamorphism and origin of Precambrian amphibolite of the New Jersey Highlands: New Brunswick, N.J., Rutgers University, unpublished Ph.D. dissertation, 156 p.

McLelland, J.M., and Chiarenzelli, J.R., 1991, Geochronological studies in the Adirondack Mountains and the implications of a Middle Proterozoic tonalitic suite, in Gower, C.F., Rivers, T., and Ryan, B., eds., Mid-Proterozoic Laurentia-Baltica: Geological Association of Canada Special Paper 38, p. 175-194.

Metsger, R.W., 1977, Notes on the Precambrian metalimestones of northern New Jersey, in Stratigraphy and applied geology of the lower Paleozoic carbonates in northwestern New Jersey: Guidebook for the 42nd annual field conference of Pennsylvania geologists, p. 48-54.

Metsger, R.W., Tennant, C.B., and Rodda, J.L., 1958, Geochemistry of the Sterling Hill zinc deposit, Sussex Co., N.J.: Geological Society of America Bulletin, v. 69, p. 775-788.

O’Conner, J.T., 1965, A classification for quartz-rich igneous rocks based on feldspar ratios: U.S. Geological Survey Professional Paper 525-B, p. B79-B84.

Offield, T.W., 1967, Bedrock geology of the Goshen-Greenwood Lake area, N.Y.: New York State Museum and Science Service Map and Chart Series, no. 9, 78 p.

Peck, F.B., 1904, The talc deposits of Phillipsburg, N.J. and Easton, Pa.: New Jersey Geological Survey, Annual Report of the State Geologist for the year 1904, p. 161-185.

Puffer, J.H., and Volkert, R.A., 1991, Generation of trondhjemite from partial melting of dacite under granulite facies conditions; an example from the New Jersey Highlands, USA: Precambrian Research, v. 51, p. 115-125.

Puffer, J.H., Volkert, R.A., and Hozik, M.J., 1991, Probable Late Proterozoic mafic dikes in the New Jersey Highlands [abs.]: Geological Society of America Abstracts with Programs, v. 23, p. 118.

Rhett, D.W., 1975, Phase relationships and petrogenetic environment of Precambrian granites of the New Jersey Highlands: 
New Brunswick, N.J., Rutgers University, unpublished Ph.D. dissertation, $157 \mathrm{p}$.

Roser, B.P., and Korsch, R.J., 1986, Determination of tectonic setting of sandstone-mudstone suite using $\mathrm{SiO}_{2}$ content and $\mathrm{K}_{2} \mathrm{O} / \mathrm{Na}_{2} \mathrm{O}$ ratio: Journal of Geology, v. 94, p. 635-650.

Shand, S.J., 1949, Eruptive rocks: New York, John Wiley and Sons, $488 \mathrm{p}$.

Sims, P.K., 1958, Geology and magnetite deposits of the Dover district, Morris County, New Jersey: U.S. Geological Survey Professional Paper 287, $162 \mathrm{p}$.

Sims, P.K., and Leonard, B.F., 1952, Geology of the Andover mining district, Sussex County, New Jersey: New Jersey Department of Conservation and Economic Development Bulletin 62, $46 \mathrm{p}$.

Spencer, A.C., Kümmel, H.B., Wolff, J.E., Salisbury, R.D., and Palache, C., 1908, Franklin Furnace, New Jersey: U.S. Geological Survey Geologic Atlas, Folio 161, 27 p.

Streckeisen, Albert, 1976, To each plutonic rock its proper name: Earth Science Reviews, v. 12, p. 1-33.

Sylvester, P.J., 1989, Post-collisional alkaline granites: Journal of Geology, v. 97, p. 261-280.

Van De Kamp, P.C., Leake, B.E., and Senior, A., 1976, The petrography and geochemistry of some Californian arkoses with application to identifying gneisses of metasedimentary origin: Journal of Geology, v. 84, p. 195-212.

Volkert, R.A., 1993, Geology of the Middle Proterozoic rocks of the New Jersey Highlands, in Puffer, J.H., ed., Geologic traverse across the Precambrian rocks of the New Jersey Highlands: Field guide and proceedings of the tenth annual meeting of the Geological Association of New Jersey, p. 23 55 .

1995, The Byram and Lake Hopatcong Intrusive Suites: Geochemistry and petrogenetic relationship of A-type granites from the New Jersey Highlands: Northeastern Geology and Environmental Sciences, v. 17, p. 247-258.

Volkert, R.A., and Drake, A.A., Jr., 1990, New geologic map of the New Jersey Highlands [abs.]: Geological Society of America Abstracts with Programs, v. 22, p. 76-77.

1998, The Vernon Supersuite: Mesoproterozoic A-type granitoid rocks in the New Jersey Highlands: Northeastern Geology and Environmental Sciences, v. 20, no. 1, p. 39-43.

Volkert, R.A., Drake, A.A., Jr., Hull, J.M., and Koto, R.Y., 1986, Road $\log$ for the field trip on the geology of the New Jersey Highlands, in Husch, J.M., and Goldstein, F.R., eds., Geology of the New Jersey Highlands and radon in New Jersey: Field guide and proceedings of the third annual meeting of the Geological Association of New Jersey, p. 67-116.

Volkert, R.A., Markewicz, F.J., and Drake, A.A., Jr., 1990, Bedrock geologic map of the Chester quadrangle, Morris County, New Jersey: New Jersey Geological Survey Geologic Map Series GMS 90-1, scale 1:24,000.

Volkert, R.A., Monteverde, D.H., and Drake, A.A., Jr., 1989, Geologic map of the Stanhope quadrangle, Morris and Sussex Counties, New Jersey: U.S. Geological Survey Geologic Quadrangle Map GQ-1671, scale 1:24,000.

1995, Bedrock geologic map of the Hackettstown quadrangle, Morris, Warren, and Hunterdon Counties, New Jersey: New Jersey Geological Survey Geologic Map Series GMS 94-1, scale 1:24,000.

Volkert, R.A., and Puffer, J.H., 1995, Late Proterozoic diabase dikes of the New Jersey Highlands-A remnant of Iapetan rifting in the north-central Appalachians, in Geologic studies in New Jersey and eastern Pennsylvania: U.S. Geological Survey Professional Paper 1565-A, 22 p.

Whalen, J.B., and Currie, K.L., 1990, The Topsails igneous suite, western Newfoundland; fractionation and magma mixing in an "orogenic" A-type granite suite, in Stein, H.J., and Hannah, J.L., eds., Ore-bearing granite systems; petrogenesis and mineralizing processes: Geological Society of America Special Paper 246, p. 287-299.

Whalen, J.B., Currie, K.L., and Chappell, B.W., 1987, A-type granites; geochemical characteristics, discrimination and petrogenesis: Contributions to Mineralogy and Petrology, v. 95 , p. 407-419.

White, A.J.R., and Chappell, B.W., 1983, Granitoid types and their distribution in the Lachlan fold belt, southeastern Australia: Geological Society of America Memoir 159, p. 21-34.

Wolff, J.E., and Brooks, A.H., 1898, The age of the Franklin white limestone of Sussex County, New Jersey: U.S. Geological Survey 18th Annual Report, pt. 2, p. 425-457.

Young, D.A., 1969, Petrology and structure of the west-central New Jersey Highlands: Providence, R.I., Brown University, unpublished Ph.D. dissertation, 194 p.

1972, A quartz syenite intrusion in the New Jersey Highlands: Journal of Petrology, v. 13, p. 511-528.

Young, D.A., and Icenhower, J.P., 1989, A metamorphosed anorthosite sill in the New Jersey Highlands: Northeastern Geology, v. 11, p. 56-64. 


\section{TABLES 1-18}

[Each table includes descriptions of samples analyzed for this study and of collection localities. Many of these localities are on private property, and permission must be obtained from property owners prior to accessing their land. Where listed, minerals are in order of increasing abundance. Quadrangle locations are in figure 1] 
Table 1. Major-oxide and trace-element concentrations and CIPW norms of leucocratic rocks of the Losee Metamorphic Suite, New Jersey Highlands.

[Analyses by X-ray fluorescence spectrometry except that $\mathrm{FeO}$ contents were determined by potentiometric titration (Jackson and others, 1987). Analyses by XRAL Activation Services, Ann Arbor, Mich., for all samples but three; analyses of samples F1, 3, and 994 by U.S. Geological Survey, Reston, Va. NA, not analyzed. Sample localities are described following this table]

\begin{tabular}{|c|c|c|c|c|c|c|c|}
\hline & \multicolumn{7}{|c|}{ Quartz-oligoclase gneiss (Ylo) } \\
\hline & 471 & 472 & 28 & 638 & 36 & 23 & 56 \\
\hline \multicolumn{8}{|c|}{ Major oxides and loss on ignition (LOI), in weight percent } \\
\hline $\mathrm{SiO}_{2} \ldots \ldots \ldots \ldots \ldots \ldots$ & 70.40 & 75.50 & 64.40 & 71.40 & 67.50 & 74.90 & 71.10 \\
\hline $\mathrm{TiO}_{2} \ldots \ldots \ldots \ldots \ldots \ldots \ldots \ldots$ & .42 & .24 & .49 & .17 & .23 & .33 & .44 \\
\hline $\mathrm{Al}_{2} \mathrm{O}_{3} \ldots \ldots \ldots \ldots \ldots \ldots \ldots \ldots$ & 15.20 & 12.90 & 16.00 & 16.40 & 18.20 & 13.00 & 15.30 \\
\hline $\mathrm{Fe}_{2} \mathrm{O}_{3} \ldots \ldots \ldots \ldots \ldots \ldots \ldots$ & 1.10 & 1.99 & 1.82 & .57 & .64 & .44 & .68 \\
\hline $\mathrm{FeO}$ & 1.30 & .80 & 2.50 & .80 & 1.00 & .40 & 1.30 \\
\hline $\mathrm{MgO}$ & 1.37 & .38 & 2.02 & .45 & .88 & .56 & .71 \\
\hline $\mathrm{CaO}$ & 2.21 & 2.79 & 4.39 & 4.05 & 3.92 & 1.16 & 2.75 \\
\hline $\mathrm{Na}_{2} \mathrm{O} \ldots \ldots \ldots \ldots \ldots \ldots \ldots \ldots$ & 5.45 & 3.97 & 4.68 & 5.12 & 5.62 & 6.95 & 5.19 \\
\hline $\mathrm{K}_{2} \mathrm{O} \ldots \ldots \ldots \ldots \ldots \ldots \ldots \ldots$ & 1.98 & 1.10 & 1.10 & .83 & 1.71 & 1.54 & 2.19 \\
\hline $\mathrm{P}_{2} \mathrm{O}_{5} \ldots \ldots \ldots \ldots \ldots \ldots \ldots \ldots$ & .06 & .03 & .15 & .06 & .10 & .04 & .11 \\
\hline $\mathrm{MnO}$ & .03 & .02 & .08 & .06 & .03 & .01 & .02 \\
\hline LOI............................... & .62 & .85 & .93 & .31 & .47 & .54 & .47 \\
\hline Total.......................... & 100.14 & 100.57 & 98.56 & 100.22 & 100.30 & 99.87 & 100.26 \\
\hline \multicolumn{8}{|c|}{ Trace elements, in parts per million } \\
\hline Ва ….............................. & 390 & 130 & 220 & 450 & 450 & 290 & 1,000 \\
\hline $\mathrm{Cr}$ & 30 & 30 & 40 & 20 & 20 & 33 & 28 \\
\hline $\mathrm{Nb}$ & 10 & 20 & $<10$ & 10 & 20 & 30 & $<10$ \\
\hline 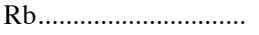 & 50 & 50 & 20 & 30 & 80 & 40 & 60 \\
\hline $\mathrm{Sr}$ & 450 & 160 & 610 & 790 & 750 & 80 & 650 \\
\hline 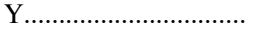 & $<10$ & 10 & $<10$ & 10 & $<10$ & 80 & 10 \\
\hline 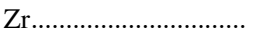 & 80 & 380 & 80 & 40 & 70 & 330 & 170 \\
\hline \multicolumn{8}{|c|}{ CIPW norms, in weight percent } \\
\hline Qtz.............................. & 24.13 & 41.74 & 20.17 & 28.97 & 18.39 & 26.67 & 25.57 \\
\hline Or ............................ & 11.70 & 6.50 & 6.50 & 4.91 & 10.11 & 9.10 & 12.94 \\
\hline $\mathrm{Ab}$ & 46.12 & 33.59 & 39.60 & 43.32 & 47.56 & 58.30 & 43.92 \\
\hline 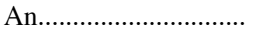 & 10.57 & 13.65 & 19.40 & 19.32 & 18.79 & - & 11.98 \\
\hline С & .22 & .18 & - & - & .22 & - & - \\
\hline Wo & - & - & - & - & - & .68 & - \\
\hline Di ......................... & - & - & 1.13 & .31 & - & 3.01 & .77 \\
\hline 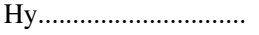 & 4.25 & .95 & 6.91 & 1.80 & 3.18 & - & 2.53 \\
\hline 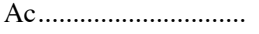 & - & - & - & - & - & .45 & - \\
\hline 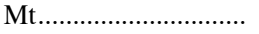 & 1.59 & 1.95 & 2.64 & .83 & .93 & .37 & .99 \\
\hline Il & .80 & .46 & .93 & .32 & .44 & .63 & .84 \\
\hline 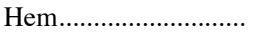 & - & .65 & - & - & - & .03 & - \\
\hline Аp & .14 & .07 & .35 & .14 & .23 & .09 & .25 \\
\hline $\mathrm{Ru}$ & - & - & - & - & - & - & - \\
\hline
\end{tabular}


Table 1. Major-oxide and trace-element concentrations and CIPW norms of leucocratic rocks of the Losee Metamorphic Suite, New Jersey Highlands - Continued.

\begin{tabular}{|c|c|c|c|c|c|c|c|}
\hline & \multicolumn{7}{|c|}{ Quartz-oligoclase gneiss (Ylo)-Continued } \\
\hline & B1 & F79 & 141 & 275 & F1 & 3 & 46 \\
\hline \multicolumn{8}{|c|}{ Major oxides and loss on ignition (LOI), in weight percent } \\
\hline 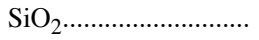 & 77.20 & 69.00 & 76.90 & 64.90 & 73.20 & 62.90 & 69.80 \\
\hline $\mathrm{TiO}_{2} \ldots \ldots \ldots \ldots \ldots \ldots \ldots \ldots$ & .23 & .20 & .25 & .45 & .15 & .94 & .34 \\
\hline $\mathrm{Al}_{2} \mathrm{O}_{3} \ldots \ldots \ldots \ldots \ldots \ldots \ldots$ & 12.20 & 17.30 & 12.10 & 16.30 & 15.30 & 15.60 & 14.80 \\
\hline $\mathrm{Fe}_{2} \mathrm{O}_{3} \ldots \ldots \ldots \ldots \ldots \ldots \ldots$ & .88 & .51 & .86 & 1.77 & .37 & 1.40 & .97 \\
\hline $\mathrm{FeO} \ldots \ldots \ldots \ldots \ldots \ldots \ldots \ldots \ldots \ldots$ & .60 & .70 & .50 & 2.40 & .56 & 4.00 & 1.70 \\
\hline $\mathrm{MgO}$ & .39 & .80 & .56 & 1.76 & .29 & 2.50 & .91 \\
\hline $\mathrm{CaO}$ & 1.09 & 4.16 & 1.50 & 4.72 & 2.80 & 4.30 & 2.90 \\
\hline $\mathrm{Na}_{2} \mathrm{O}$ & 5.94 & 5.12 & 6.22 & 4.51 & 4.70 & 4.20 & 4.68 \\
\hline $\mathrm{K}_{2} \mathrm{O}$ & .62 & 1.36 & .53 & 1.46 & 1.40 & 1.30 & 2.70 \\
\hline $\mathrm{P}_{2} \mathrm{O}_{5} \ldots \ldots \ldots \ldots \ldots \ldots \ldots \ldots$ & .04 & .10 & .03 & .18 & .04 & .25 & .13 \\
\hline $\mathrm{MnO}$ & .03 & .03 & .03 & .07 & .07 & .07 & .03 \\
\hline LOI.............................. & .54 & 1.16 & .70 & .35 & .43 & 1.38 & .70 \\
\hline Total ......................... & 99.76 & $\overline{100.44}$ & $\overline{100.18}$ & 98.87 & 99.31 & 98.84 & 99.66 \\
\hline \multicolumn{8}{|c|}{ Trace elements, in parts per million } \\
\hline 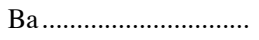 & 80 & 650 & 140 & 460 & NA & NA & 1,200 \\
\hline $\mathrm{Cr}$ & 30 & 20 & 10 & 250 & NA & NA & 20 \\
\hline $\mathrm{Nb}$ & $<10$ & $<10$ & 20 & 20 & NA & NA & $<10$ \\
\hline $\mathrm{Rb}$ & 20 & 40 & 30 & 10 & NA & NA & $<10$ \\
\hline $\mathrm{Sr}$ & 80 & 1000 & 120 & 730 & NA & NA & 510 \\
\hline $\mathrm{Y}$ & 40 & 10 & 70 & $<10$ & NA & NA & $<10$ \\
\hline $\mathrm{Zr}$ & 340 & 40 & 380 & 110 & NA & NA & 190 \\
\hline \multicolumn{8}{|c|}{ CIPW norms, in weight percent } \\
\hline Qtz.................................. & 37.52 & 23.92 & 35.53 & 20.29 & 33.91 & 19.09 & 24.67 \\
\hline Or & 3.66 & 8.04 & 3.13 & 8.63 & 8.27 & 7.68 & 15.96 \\
\hline $\mathrm{Ab}$ & 50.26 & 43.32 & 52.63 & 38.16 & 39.77 & 35.54 & 39.60 \\
\hline 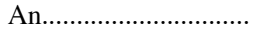 & 4.80 & 19.99 & 3.53 & 19.92 & 13.63 & 19.70 & 11.40 \\
\hline С & - & .08 & - & - & 1.06 & .06 & - \\
\hline Wo & - & - & - & - & - & - & - \\
\hline $\mathrm{Di}$ & .27 & - & 2.89 & 1.88 & - & - & 1.75 \\
\hline Ну & .89 & 2.58 & .05 & 5.80 & 1.33 & 10.99 & 3.22 \\
\hline Ac & - & - & - & - & - & - & - \\
\hline 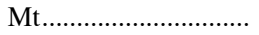 & 1.28 & .74 & .98 & 2.57 & .54 & 2.03 & 1.41 \\
\hline Il & .44 & .38 & .47 & .85 & .28 & 1.79 & .65 \\
\hline 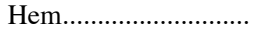 & - & - & .18 & - & - & - & - \\
\hline Ар. & .09 & .23 & .07 & .42 & .09 & .58 & .30 \\
\hline Ru................................ & - & - & - & - & - & - & - \\
\hline
\end{tabular}


Table 1. Major-oxide and trace-element concentrations and CIPW norms of leucocratic rocks of the Losee Metamorphic Suite, New Jersey Highlands - Continued.

\begin{tabular}{|c|c|c|c|c|c|c|}
\hline & \multicolumn{5}{|c|}{ Quartz-oligoclase gneiss (Ylo)_Continued } & \multirow{2}{*}{$\begin{array}{c}\begin{array}{c}\text { Albite- } \\
\text { oligoclase } \\
\text { granite (Yla) }\end{array} \\
\text { H380 }\end{array}$} \\
\hline & 175 & 94 & 128 & 104 & 7 & \\
\hline \multicolumn{7}{|c|}{ Major oxides and loss on ignition (LOI), in weight percent } \\
\hline 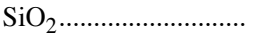 & 73.20 & 69.70 & 65.80 & 72.90 & 66.60 & 77.90 \\
\hline 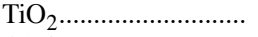 & .11 & .19 & .51 & .47 & .30 & .10 \\
\hline $\mathrm{Al}_{2} \mathrm{O}_{3} \ldots \ldots \ldots \ldots \ldots \ldots \ldots \ldots$ & 15.60 & 17.60 & 16.00 & 13.10 & 19.00 & 12.10 \\
\hline $\mathrm{Fe}_{2} \mathrm{O}_{3} \ldots \ldots \ldots \ldots \ldots \ldots \ldots$ & .38 & .56 & 1.75 & 1.60 & 1.01 & .17 \\
\hline $\mathrm{FeO}$ & .10 & .80 & 2.50 & .90 & .20 & .30 \\
\hline $\mathrm{MgO}$ & .24 & .66 & 1.93 & .52 & .18 & .20 \\
\hline $\mathrm{CaO}$ & 1.77 & 4.64 & 4.81 & 2.79 & 3.44 & .77 \\
\hline $\mathrm{Na}_{2} \mathrm{O}$ & 6.92 & 5.10 & 4.56 & 5.96 & 6.56 & 4.95 \\
\hline $\mathrm{K}_{2} \mathrm{O}$ & 1.41 & .85 & 1.62 & 1.21 & 1.43 & 2.77 \\
\hline $\mathrm{P}_{2} \mathrm{O}_{5}$ & .03 & .08 & .18 & .13 & .03 & .02 \\
\hline $\mathrm{MnO}$ & .01 & .03 & .07 & .03 & $<.01$ & .01 \\
\hline LOI ........................... & .54 & .39 & .16 & .70 & .25 & .47 \\
\hline Total....................... & 100.31 & 100.60 & 99.89 & 100.31 & 99.00 & 99.76 \\
\hline \multicolumn{7}{|c|}{ Trace elements, in parts per million } \\
\hline $\mathrm{Ba}$ & 1,000 & 480 & 410 & 260 & 220 & 420 \\
\hline 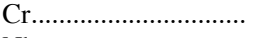 & 20 & 20 & 30 & 30 & NA & 10 \\
\hline $\mathrm{Nb}$ & 20 & $<10$ & 10 & 10 & $<10$ & 10 \\
\hline $\mathrm{Rb}$ & 30 & 30 & 40 & 20 & 20 & 40 \\
\hline $\mathrm{Sr}$ & 880 & 800 & 630 & 340 & 130 & 120 \\
\hline Y & $<10$ & $<10$ & 10 & 30 & 10 & 20 \\
\hline $\mathrm{Zr}$ & 50 & 30 & 120 & 360 & 180 & 80 \\
\hline \multicolumn{7}{|c|}{ CIPW norms, in weight percent } \\
\hline 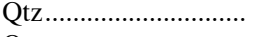 & 23.75 & 25.74 & 20.22 & 28.85 & 15.41 & 36.72 \\
\hline Or & 8.33 & 5.02 & 9.57 & 7.15 & 8.45 & 16.37 \\
\hline $\mathrm{Ab}$ & 58.56 & 43.16 & 38.59 & 50.43 & 55.51 & 41.89 \\
\hline 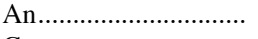 & 7.34 & 22.50 & 18.41 & 5.42 & 16.87 & 2.62 \\
\hline $\mathrm{C}$ & - & .05 & - & - & .48 & - \\
\hline Wo ............................... & - & - & - & 1.66 & - & - \\
\hline 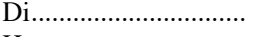 & .97 & - & 3.47 & 2.79 & - & .87 \\
\hline 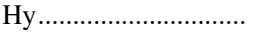 & .15 & 2.39 & 5.56 & - & .45 & .34 \\
\hline Ac & - & - & - & - & - & - \\
\hline Mt .............................. & .04 & .81 & 2.54 & 1.64 & - & .25 \\
\hline Il & .21 & .36 & .97 & .89 & .42 & .19 \\
\hline 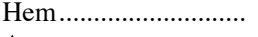 & .36 & - & - & .47 & 1.01 & - \\
\hline Ap & .07 & .19 & .42 & .30 & .07 & .05 \\
\hline $\mathrm{Ru}$ & - & - & - & - & .08 & - \\
\hline
\end{tabular}


Table 1. Major-oxide and trace-element concentrations and CIPW norms of leucocratic rocks of the Losee Metamorphic Suite, New Jersey Highlands-Continued.

\begin{tabular}{|c|c|c|c|c|c|c|}
\hline & \multicolumn{6}{|c|}{ Biotite-quartz-oligoclase gneiss (Ylb) } \\
\hline & W66 & 255 & 435 & 994 & 664 & W284 \\
\hline \multicolumn{7}{|c|}{ Major oxides and loss on ignition (LOI), in weight percent } \\
\hline $\mathrm{SiO}_{2} \ldots \ldots \ldots$ & 63.30 & 61.10 & 69.00 & 71.90 & 62.10 & 62.50 \\
\hline $\mathrm{TiO}_{2} \ldots \ldots \ldots \ldots \ldots \ldots \ldots \ldots$ & .88 & .91 & .53 & .36 & 1.02 & .76 \\
\hline $\mathrm{Al}_{2} \mathrm{O}_{3} \ldots \ldots \ldots \ldots \ldots \ldots \ldots \ldots$ & 17.00 & 16.20 & 15.20 & 14.80 & 13.90 & 17.30 \\
\hline $\mathrm{Fe}_{2} \mathrm{O}_{3} \ldots \ldots$ & 1.62 & 3.61 & .85 & .50 & 4.26 & 1.04 \\
\hline $\mathrm{FeO}$ & 2.30 & 3.80 & 2.00 & 1.20 & 4.90 & 1.60 \\
\hline $\mathrm{MgO}$ & 3.66 & 2.99 & .99 & 1.10 & 3.11 & 3.36 \\
\hline $\mathrm{CaO}$ & 2.66 & 3.43 & 3.29 & 2.90 & 3.05 & 2.19 \\
\hline $\mathrm{Na}_{2} \mathrm{O} \ldots \ldots \ldots \ldots \ldots \ldots \ldots \ldots$ & 6.41 & 5.48 & 5.11 & 4.30 & 3.12 & 6.89 \\
\hline $\mathrm{K}_{2} \mathrm{O}$ & 2.05 & 1.93 & 2.13 & 1.20 & 2.69 & 2.10 \\
\hline $\mathrm{P}_{2} \mathrm{O}_{5} \ldots \ldots \ldots \ldots \ldots \ldots \ldots$ & .22 & .19 & .15 & .07 & .22 & .15 \\
\hline $\mathrm{MnO}$ & .02 & .02 & .05 & .04 & .11 & $<.01$ \\
\hline 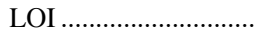 & .47 & .54 & .85 & .77 & 1.05 & .35 \\
\hline Total .......................... & 100.59 & 100.20 & 100.15 & 99.14 & 99.53 & 98.24 \\
\hline \multicolumn{7}{|c|}{ Trace elements, in parts per million } \\
\hline Ва & 300 & 670 & 930 & NA & 350 & 200 \\
\hline $\mathrm{Cr}$ & 80 & 100 & 30 & NA & NA & NA \\
\hline $\mathrm{Nb}$ & 20 & 20 & 10 & NA & 10 & 10 \\
\hline $\mathrm{Rb}$ & 180 & 110 & 50 & NA & 80 & 100 \\
\hline $\mathrm{Sr}$ & 130 & 140 & 590 & NA & 80 & 140 \\
\hline Y & 160 & 20 & $<10$ & NA & 30 & 30 \\
\hline 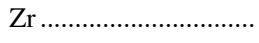 & 180 & 190 & 210 & NA & 180 & 190 \\
\hline \multicolumn{7}{|c|}{ CIPW norms, in weight percent } \\
\hline Qtz & 7.01 & 9.82 & 22.69 & 34.31 & 21.28 & 4.73 \\
\hline Or.......................... & 12.12 & 11.41 & 12.59 & 7.09 & 15.90 & 12.41 \\
\hline $\mathrm{Ab}$ & 54.24 & 46.37 & 43.24 & 36.39 & 26.40 & 58.30 \\
\hline An & 11.56 & 13.91 & 12.25 & 13.36 & 13.69 & 9.88 \\
\hline $\mathrm{C}$ & - & - & - & 1.53 & .84 & .07 \\
\hline Wo & - & - & - & - & - & - \\
\hline Di & .16 & 1.50 & 2.55 & - & - & - \\
\hline Ну & 10.51 & 9.26 & 3.40 & 4.01 & 11.74 & 9.19 \\
\hline Ac & - & - & - & - & - & - \\
\hline Mt & 2.35 & 5.23 & 1.23 & .72 & 6.18 & 1.51 \\
\hline Il „........... & 1.67 & 1.73 & 1.01 & .68 & 1.94 & 1.44 \\
\hline Hem & - & - & - & - & - & - \\
\hline Ар & .51 & .44 & .35 & .16 & .51 & .35 \\
\hline $\mathrm{Ru}$ & - & - & - & - & - & - \\
\hline
\end{tabular}




\section{Sample Descriptions and Collection Localities-Table 1}

471-Medium-grained, foliated biotite-quartz-plagioclase gneiss. North side of service road, $1,950 \mathrm{ft}$ east-northeast of north end of Lake Ioscoe; Wanaque 7.5-min quadrangle.

472-Medium-coarse-grained biotite-quartz-plagioclase gneiss. South side of service road, 1,200 ft southwest of west end of Wolf Den Dam, Wanaque Reservoir; Wanaque 7.5-min quadrangle.

28-Hornblende-biotite-quartz-plagioclase gneiss. East side of road, 1,350 ft southwest of southwest end of Sheppard Pond; Sloatsburg 7.5-min quadrangle.

638-Well-foliated garnet-biotite-quartz-plagioclase gneiss. Low ridge west of New Jersey Route 206, 1,500 ft northwest of intersection of Routes 206 and 607; Stanhope 7.5-min quadrangle.

36-Medium-grained quartz-plagioclase gneiss. West side of New Jersey Route 667, 0.8 mi north of Independence Corner; Hamburg 7.5-min quadrangle.

23-Quartz-plagioclase gneiss. Along Bear Swamp Brook, $1 \mathrm{mi}$ northwest of New Jersey Route 202; Ramsey 7.5-min quadrangle.

56-Homogeneous biotite-quartz-plagioclase gneiss. East side of New Jersey Route 515, 1,200 ft northeast of boundary with Hamburg 7.5-min quadrangle; Wawayanda 7.5-min quadrangle.

B1-Clinopyroxene-hornblende-biotite-quartz-plagioclase gneiss. Crest of Jenny Jump Mountain, approximately $0.9 \mathrm{mi}$ east-southeast of Shiloh; Blairstown 7.5-min quadrangle.

F79-Hornblende-biotite-quartz-plagioclase gneiss. North side of Beaver Lake Road, $500 \mathrm{ft}$ west of south end of Beaver Lake; Franklin 7.5-min quadrangle.

141-Homogeneous quartz-plagioclase gneiss. East side of Lake Just-It Road, 0.84 mi northeast of intersection of Mountain Lake and Jenny Jump Brook; Washington 7.5-min quadrangle.

275-Clinopyroxene-hornblende-quartz-plagioclase gneiss. Northbound Interstate-287, approximately $300 \mathrm{ft}$ west of Lake Inez; Wanaque 7.5-min quadrangle.

F1 - Homogeneous quartz-plagioclase gneiss. Northbound New Jersey Route 15, north side of Sparta Interchange, west of Blue Heron Lake; Franklin 7.5-min quadrangle.

3-Clinopyroxene-hornblende-quartz-plagioclase gneiss. Along Peapack Brook, $600 \mathrm{ft}$ south of intersection of Fox Chase Road and Peapack Brook; Chester 7.5-min quadrangle.
46-Clinopyroxene-biotite-hornblende-quartz-plagioclase gneiss. East side of ridge crest, $0.56 \mathrm{mi}$ northeast of intersection of Indian Grove Brook and Hardscrabble Road; Bernardsville 7.5-min quadrangle.

175-Weakly foliated quartz-plagioclase gneiss. East side of unnamed stream, approximately $1.2 \mathrm{mi}$ south-southeast of Cokesbury; Califon 7.5-min quadrangle.

94-Foliated garnet-biotite-quartz-plagioclase gneiss. North side of Mansfield Drive, $400 \mathrm{ft}$ west of Lubbers Run; Stanhope 7.5-min quadrangle.

128-Biotite-hornblende-quartz-plagioclase gneiss. East side of Alta Vista Drive, 1,100 ft west-northwest of north end of Skyline Lakes; Wanaque 7.5-min quadrangle.

104-Clinopyroxene-hornblende-quartz-plagioclase gneiss. East side of Skyline Drive, $200 \mathrm{ft}$ north of Passaic-Bergen County boundary; Wanaque 7.5-min quadrangle.

7-Weakly foliated quartz-plagioclase gneiss. North side of Wanaque River beneath Monksville Reservoir dam, west of Greenwood Lake Road; Wanaque 7.5-min quadrangle.

H380 - Medium-coarse-grained quartz-plagioclase alaskite. West side of Central Railroad of New Jersey tracks at intersection with powerline, west of South Branch Raritan River; High Bridge 7.5-min quadrangle.

W66-Medium-grained, well-foliated, biotite-quartz-plagioclase gneiss. South side of South Road at bend, southeast end of Glen Wild Lake; Wanaque 7.5-min quadrangle.

255-Biotite-quartz-plagioclase gneiss. West side of Rocky Mountain, approximately $400 \mathrm{ft}$ southeast of south end of Bear Swamp Lake; Ramsey 7.5-min quadrangle.

435-Well-layered biotite-quartz-plagioclase gneiss. Hill approximately $350 \mathrm{ft}$ east of north end of Mastodon Lake; Wawayanda 7.5-min quadrangle.

994-Foliated garnet-biotite-quartz-plagioclase gneiss. Southound New Jersey Route 15, approximately $0.5 \mathrm{mi}$ south of intersection of Route 15 with abandoned railroad tracks; Newton East 7.5-min quadrangle.

664-Garnet-biotite-quartz-plagioclase gneiss. Pochuck Mountain, east side of ridge crest, $0.18 \mathrm{mi}$ due south of south shore of Lake Pochung; Hamburg 7.5-min quadrangle.

W284-Quartz-biotite-plagioclase gneiss. East side of Burnt Meadow Road, $200 \mathrm{ft}$ north of Burnt Meadow Brook; Wanaque 7.5-min quadrangle. 
Table 2. Major-oxide and trace-element concentrations and CIPW norms of layered charnockitic rocks (Yh) of the Losee Metamorphic Suite, New Jersey Highlands.

[Analyses by X-ray fluorescence spectrometry except that $\mathrm{FeO}$ contents were determined by potentiometric titration (Jackson and others, 1987). Analyses by XRAL Activation Services, Ann Arbor, Mich., for all samples but one; analysis of sample 1106 by U.S. Geological Survey, Reston, Va. NA, not analyzed. Sample localities are described following this table]

\begin{tabular}{|c|c|c|c|c|c|c|c|}
\hline & \multicolumn{3}{|c|}{ Charnockitic andesite } & \multicolumn{4}{|c|}{ Charnockitic dacite } \\
\hline & 423 & 639 & 527 & 138 & G37 & 275 & 1106 \\
\hline \multicolumn{8}{|c|}{ Major oxides and loss on ignition (LOI), in weight percent } \\
\hline $\mathrm{SiO}_{2} \ldots \ldots \ldots \ldots \ldots$ & 60.30 & 61.60 & 58.40 & 67.20 & 66.00 & 65.30 & 66.30 \\
\hline $\mathrm{TiO}_{2} \ldots \ldots \ldots \ldots \ldots$ & 1.83 & .71 & .58 & .54 & .62 & .44 & .41 \\
\hline $\mathrm{Al}_{2} \mathrm{O}_{3} \ldots \ldots \ldots \ldots \ldots$ & 15.10 & 14.40 & 17.20 & 15.90 & 15.70 & 16.10 & 15.40 \\
\hline $\mathrm{Fe}_{2} \mathrm{O}_{3} \ldots \ldots \ldots \ldots$ & 3.71 & 1.84 & 1.98 & 1.25 & 3.15 & 1.84 & .80 \\
\hline $\mathrm{FeO} \ldots \ldots \ldots \ldots \ldots$ & 4.70 & 4.30 & 6.70 & 2.40 & 3.40 & 2.70 & 2.70 \\
\hline $\mathrm{MgO} \ldots \ldots \ldots \ldots \ldots . . . . .$. & 2.09 & 3.51 & 3.06 & 1.32 & .82 & 1.95 & 2.20 \\
\hline $\mathrm{CaO} \ldots \ldots \ldots \ldots \ldots$ & 5.68 & 5.14 & 4.82 & 4.07 & 3.75 & 4.75 & 2.00 \\
\hline $\mathrm{Na}_{2} \mathrm{O} \ldots \ldots \ldots \ldots \ldots$ & 4.07 & 4.15 & 4.07 & 4.17 & 5.02 & 4.44 & 3.50 \\
\hline $\mathrm{K}_{2} \mathrm{O} \ldots \ldots \ldots \ldots \ldots$ & 1.49 & 1.70 & 2.29 & 1.94 & 1.34 & 1.51 & 4.80 \\
\hline $\mathrm{P}_{2} \mathrm{O}_{5} \ldots \ldots \ldots \ldots \ldots \ldots$ & .61 & .22 & .20 & .16 & .21 & .18 & .27 \\
\hline $\mathrm{MnO} . . . \ldots \ldots \ldots \ldots$ & .12 & .09 & .15 & .09 & .11 & .07 & .10 \\
\hline LOI .................... & .39 & .47 & .54 & .62 & .39 & .15 & .76 \\
\hline Total .............. & $\overline{100.09}$ & $\overline{98.13}$ & $\overline{99.99}$ & $\overline{99.66}$ & $\overline{100.51}$ & $\overline{99.43}$ & $\overline{99.24}$ \\
\hline \multicolumn{8}{|c|}{ Trace elements, in parts per million } \\
\hline 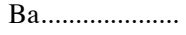 & 860 & 480 & 260 & 870 & 420 & 520 & NA \\
\hline $\mathrm{Cr}$ & 17 & 180 & 80 & 10 & $<10$ & 310 & NA \\
\hline $\mathrm{Nb}$ & 20 & $<10$ & 20 & 20 & 10 & 20 & NA \\
\hline $\mathrm{Rb}$ & 30 & 80 & 70 & 40 & 70 & 20 & NA \\
\hline $\mathrm{Sr} . \ldots \ldots \ldots \ldots \ldots \ldots \ldots \ldots \ldots \ldots \ldots$ & 570 & 320 & 150 & 590 & 320 & 750 & NA \\
\hline $\mathrm{Y}$ & 70 & 20 & 20 & $<10$ & 20 & $<10$ & NA \\
\hline $\mathrm{Zr}$ & 270 & 130 & 90 & 190 & 250 & 110 & NA \\
\hline \multicolumn{8}{|c|}{ CIPW norms, in weight percent } \\
\hline Qtz .......................... & 17.32 & 14.70 & 7.24 & 24.12 & 21.91 & 20.44 & 19.03 \\
\hline 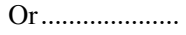 & 8.81 & 10.05 & 13.53 & 11.46 & 7.92 & 8.92 & 28.37 \\
\hline $\mathrm{Ab}$ & 34.44 & 35.12 & 34.44 & 35.29 & 42.48 & 37.57 & 29.62 \\
\hline 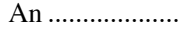 & 18.53 & 15.64 & 21.90 & 18.94 & 16.35 & 19.54 & 8.16 \\
\hline $\mathrm{C}$ & - & - & - & - & - & - & 1.46 \\
\hline Di ......................... & 4.59 & 6.86 & .59 & .17 & .74 & 2.32 & - \\
\hline 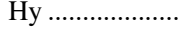 & 5.74 & 10.77 & 17.31 & 5.85 & 4.49 & 6.57 & 9.28 \\
\hline Mt ...................... & 5.38 & 2.67 & 2.87 & 1.81 & 4.57 & 2.67 & 1.16 \\
\hline 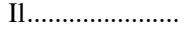 & 3.48 & 1.35 & 1.10 & 1.03 & 1.18 & .84 & .78 \\
\hline 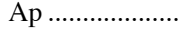 & 1.41 & .51 & .46 & .37 & .49 & .42 & .63 \\
\hline
\end{tabular}


Table 2. Major-oxide and trace-element concentrations and CIPW norms of layered charnockitic rocks (Yh) of the Losee Metamorphic Suite, New Jersey Highlands - Continued.

\begin{tabular}{|c|c|c|c|c|}
\hline & \multicolumn{4}{|c|}{ Charnockitic rhyolite } \\
\hline & 337 & 279 & 345 & 96 \\
\hline \multicolumn{5}{|c|}{ Major oxides and loss on ignition (LOI), in weight percent } \\
\hline $\mathrm{SiO}_{2} \ldots \ldots \ldots \ldots \ldots \ldots \ldots \ldots$ & 78.20 & 73.40 & 72.90 & 72.60 \\
\hline $\mathrm{TiO}_{2} \ldots \ldots \ldots \ldots \ldots \ldots \ldots$ & .49 & .30 & .26 & .30 \\
\hline $\mathrm{Al}_{2} \mathrm{O}_{3} \ldots \ldots \ldots \ldots \ldots \ldots \ldots$ & 10.20 & 13.00 & 14.20 & 10.50 \\
\hline $\mathrm{Fe}_{2} \mathrm{O}_{3} \ldots \ldots \ldots \ldots \ldots \ldots$ & .82 & .95 & 1.40 & 2.82 \\
\hline $\mathrm{FeO}$ & 1.60 & 1.60 & .90 & 2.60 \\
\hline 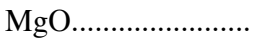 & 1.44 & 1.15 & .49 & .27 \\
\hline 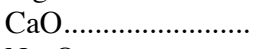 & 1.52 & 2.33 & 2.29 & 1.15 \\
\hline $\mathrm{Na}_{2} \mathrm{O} \ldots \ldots \ldots \ldots \ldots \ldots \ldots$ & 4.41 & 3.92 & 4.17 & 1.25 \\
\hline $\mathrm{K}_{2} \mathrm{O} \ldots \ldots \ldots \ldots \ldots \ldots \ldots$ & .86 & 2.78 & 3.19 & 7.49 \\
\hline $\mathrm{P}_{2} \mathrm{O}_{5} \ldots \ldots \ldots \ldots \ldots \ldots \ldots$ & .02 & .07 & .07 & .03 \\
\hline $\mathrm{MnO}$ & .04 & .04 & .04 & .06 \\
\hline LOI .......................... & .50 & .16 & .47 & .10 \\
\hline Total ................... & $\overline{100.10}$ & $\overline{99.70}$ & $\overline{100.38}$ & $\overline{99.17}$ \\
\hline \multicolumn{5}{|c|}{ Trace elements, in parts per million } \\
\hline Ва............................... & 260 & 1,200 & 640 & 1,500 \\
\hline 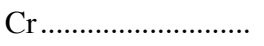 & 70 & 20 & 30 & $<10$ \\
\hline $\mathrm{Nb}$ & 10 & $<10$ & $<10$ & 20 \\
\hline $\mathrm{Rb}$ & $<10$ & $<10$ & 150 & 170 \\
\hline $\mathrm{Sr}$ & 100 & 240 & 280 & 50 \\
\hline $\mathrm{Y}$ & $<10$ & $<10$ & 10 & 10 \\
\hline $\mathrm{Zr}$ & 260 & 140 & 120 & 420 \\
\hline \multicolumn{5}{|c|}{ CIPW norms, in weight percent } \\
\hline Qtz ........................... & 43.63 & 32.97 & 30.99 & 33.93 \\
\hline Or ............................... & 5.08 & 16.43 & 18.85 & 44.26 \\
\hline $\mathrm{Ab}$ & 37.32 & 33.17 & 35.29 & 10.58 \\
\hline An .............................. & 5.50 & 9.67 & 10.61 & .92 \\
\hline $\mathrm{C}$ & - & - & - & - \\
\hline Di ............................... & 1.54 & 1.17 & .23 & 3.94 \\
\hline 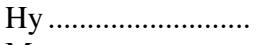 & 4.37 & 4.03 & 1.25 & .71 \\
\hline Mt ............................. & 1.19 & 1.38 & 2.03 & 4.09 \\
\hline Il................................ & .93 & .57 & .49 & .57 \\
\hline Ap .............................. & .05 & .16 & .16 & .07 \\
\hline
\end{tabular}




\section{Sample Descriptions and Collection Localities-Table 2}

423-Medium-grained, layered hypersthene-quartz-plagioclase gneiss. Intercalated with porphyritic hornblende-plagioclase amphibolite (sample 423A, table 17). South side of swamp on Allamuchy Mountain, 0.87 mi southeast of northeast end of Tranquility Lake; Tranquility 7.5-min quadrangle.

639-Hypersthene-quartz-plagioclase gneiss. West side of ridge, east of New Jersey Route 206, approximately 1.05 mi north of intersection of New Jersey Routes 206 and 607; Stanhope 7.5-min quadrangle.

527-Quartz-hypersthene-plagioclase gneiss. High Rock Mountain, 1,500 ft east of Mountain Lake; Washington 7.5-min quadrangle.

138-Hypersthene-quartz-plagioclase gneiss. West side of ridge east of Rocky Run, 0.56 mi southeast of water tower on Mt. Kipp; High Bridge 7.5-min quadrangle.

G37-Hypersthene-quartz-plagioclase gneiss. Low ridge along southeast end of Greenwood Lake; Greenwood Lake 7.5-min quadrangle.

275-Hypersthene-quartz-plagioclase gneiss. Intercalated with quartz-oligoclase gneiss (sample 275, table 1). Northbound
Interstate-287, approximately $300 \mathrm{ft}$ west of Lake Inez; Wanaque 7.5-min quadrangle.

1106-Hypersthene-quartz-plagioclase gneiss. Powerline east of New Jersey Route 517, 0.7 mi east-northeast of north end of Lake Lenape; Newton East 7.5-min quadrangle.

337-Hypersthene-quartz-plagioclase gneiss. Intercalated with quartz-plagioclase gneiss and hornblende-plagioclase amphibolite. West side of Mill Brook Avenue, 1.1 mi north of Mount Freedom; Mendham 7.5-min quadrangle.

279-Hypersthene-quartz-plagioclase gneiss. North side of low hill at Camp Washington, 1,000 ft west of pond on Electric Brook; Hackettstown 7.5-min quadrangle.

345-Hypersthene-quartz-plagioclase gneiss. Intercalated with foliated biotite-hornblende-plagioclase amphibolite. East side of Otter Hole Road, 950 ft east-southeast of Indian Trail Lake; Wanaque 7.5-min quadrangle.

96-Hypersthene-K-feldspar-quartz-plagioclase gneiss. Northbound New Jersey Route 515, approximately $0.8 \mathrm{mi}$ north of intersection of New Jersey Routes 23 and 515; Franklin 7.5-min quadrangle. 
Table 3. Major-oxide and trace-element concentrations and CIPW norms of massive charnockitic rocks (Yd) of the Losee Metamorphic Suite, New Jersey Highlands.

[Analyses by X-ray fluorescence spectrometry except that $\mathrm{FeO}$ contents were determined by potentiometric titration (Jackson and others, 1987). Analyses by XRAL Activation Services, Ann Arbor, Mich., for all samples but two; analyses of samples 746 and 108 by U.S. Geological Survey, Reston, Va. NA, not analyzed. Sample localities are described following this table]

\begin{tabular}{|c|c|c|c|c|c|c|c|}
\hline & 746 & 114 & 108 & 31 & 561 & 603 & 43 \\
\hline \multicolumn{8}{|c|}{ Major oxides and loss on ignition (LOI), in weight percent } \\
\hline $\mathrm{SiO}_{2} \ldots \ldots \ldots \ldots \ldots \ldots \ldots$ & 67.40 & 50.77 & 65.40 & 68.70 & 52.40 & 54.60 & 46.70 \\
\hline $\mathrm{TiO}_{2}$ & .83 & 1.08 & .86 & .45 & .26 & .60 & .51 \\
\hline $\mathrm{Al}_{2} \mathrm{O}_{3} \ldots \ldots \ldots \ldots \ldots \ldots \ldots$ & 15.90 & 14.26 & 15.90 & 15.60 & 20.60 & 13.80 & 21.00 \\
\hline $\mathrm{Fe}_{2} \mathrm{O}_{3} \ldots \ldots \ldots \ldots$ & 1.63 & 5.70 & .60 & .77 & 1.93 & 3.90 & 2.88 \\
\hline $\mathrm{FeO}$ & 2.20 & 7.70 & 3.60 & 2.60 & 3.10 & 9.10 & 6.40 \\
\hline $\mathrm{MgO}$ & 1.16 & 6.67 & 2.30 & 1.17 & 6.43 & 4.97 & 6.46 \\
\hline $\mathrm{CaO}$ & 4.58 & 10.08 & 3.10 & 3.98 & 12.50 & 9.00 & 13.50 \\
\hline $\mathrm{Na}_{2} \mathrm{O} \ldots \ldots \ldots \ldots \ldots \ldots \ldots \ldots$ & 4.49 & 3.40 & 4.30 & 5.27 & 2.50 & 3.14 & 1.60 \\
\hline $\mathrm{K}_{2} \mathrm{O}$ & .94 & .38 & 2.40 & 1.16 & .30 & .34 & .39 \\
\hline $\mathrm{P}_{2} \mathrm{O}_{5} \ldots \ldots \ldots \ldots \ldots \ldots \ldots \ldots \ldots \ldots \ldots \ldots \ldots \ldots$ & .37 & .13 & .22 & .12 & .06 & .07 & .08 \\
\hline $\mathrm{MnO}$ & .05 & .18 & .07 & .06 & .09 & .26 & .14 \\
\hline LOI & .75 & .68 & .58 & .08 & .23 & .01 & .23 \\
\hline Total ........................ & 100.30 & 101.03 & 99.33 & 99.96 & 100.40 & 99.79 & 99.89 \\
\hline \multicolumn{8}{|c|}{ Trace elements, in parts per million } \\
\hline 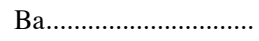 & NA & 53 & NA & 160 & 90 & 60 & 60 \\
\hline $\mathrm{Cr}$ & NA & NA & NA & 20 & 230 & 30 & 40 \\
\hline $\mathrm{Nb}$ & NA & NA & NA & 10 & $<10$ & $<10$ & $<10$ \\
\hline $\mathrm{Rb}$ & NA & NA & NA & 30 & 10 & 10 & 10 \\
\hline $\mathrm{Sr}$ & NA & 180 & NA & 330 & 830 & 240 & 810 \\
\hline $\mathrm{Y}$ & NA & NA & NA & 10 & 10 & 10 & $<10$ \\
\hline $\mathrm{Zr}$ & NA & 34 & NA & 120 & $<10$ & $<10$ & $<10$ \\
\hline \multicolumn{8}{|c|}{ CIPW norms, in weight percent } \\
\hline 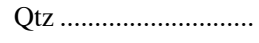 & 26.62 & 0.53 & 19.99 & 22.82 & 2.55 & 7.30 & - \\
\hline 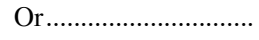 & 5.56 & 2.25 & 14.18 & 6.86 & 1.77 & 2.01 & 2.30 \\
\hline $\mathrm{Ab}$ & 37.99 & 28.77 & 36.39 & 44.59 & 21.15 & 26.57 & 13.54 \\
\hline An & 20.12 & 22.53 & 12.93 & 15.49 & 44.10 & 22.56 & 48.97 \\
\hline $\mathrm{C}$ & .12 & - & 1.49 & - & - & - & - \\
\hline Di & - & 21.33 & - & 2.89 & 13.94 & 17.93 & 14.19 \\
\hline 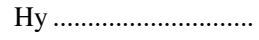 & 4.30 & 14.27 & 10.55 & 4.98 & 13.22 & 16.46 & 8.28 \\
\hline $\mathrm{Ol}$ & - & - & - & - & - & - & 7.05 \\
\hline 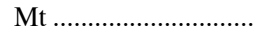 & 2.36 & 8.26 & .87 & 1.12 & 2.80 & 5.65 & 4.18 \\
\hline Il ................................ & 1.58 & 2.05 & 1.63 & .85 & .49 & 1.14 & .97 \\
\hline Ap & .86 & .30 & .51 & .28 & .14 & .16 & .19 \\
\hline Сc & .07 & .09 & .36 & - & - & - & - \\
\hline
\end{tabular}


TABLE 3

Table 3. Major-oxide and trace-element concentrations and CIPW norms of massive charnockitic rocks (Yd) of the Losee Metamorphic Suite, New Jersey Highlands-Continued.

\begin{tabular}{|c|c|c|c|c|c|c|c|}
\hline & 219 & 80 & W172 & 68 & $\mathrm{H} 381$ & 18 & 73 \\
\hline \multicolumn{8}{|c|}{ Major oxides and loss on ignition (LOI), in weight percent } \\
\hline $\mathrm{SiO}_{2} \ldots \ldots \ldots \ldots \ldots \ldots \ldots \ldots \ldots \ldots \ldots \ldots \ldots$ & 58.00 & 56.80 & 55.40 & 57.20 & 51.70 & 67.30 & 57.40 \\
\hline $\mathrm{TiO}_{2} \ldots \ldots \ldots \ldots \ldots \ldots \ldots \ldots$ & 1.02 & .62 & 1.45 & 1.08 & 1.58 & .29 & 1.33 \\
\hline $\mathrm{Al}_{2} \mathrm{O}_{3} \ldots \ldots \ldots \ldots \ldots \ldots \ldots \ldots$ & 16.20 & 19.20 & 17.30 & 16.80 & 15.30 & 16.10 & 17.90 \\
\hline $\mathrm{Fe}_{2} \mathrm{O}_{3} \ldots \ldots \ldots \ldots \ldots \ldots \ldots \ldots \ldots \ldots \ldots \ldots \ldots$ & 3.22 & 1.85 & 1.55 & 2.06 & 2.00 & 1.38 & 2.68 \\
\hline $\mathrm{FeO}$ & 4.50 & 3.60 & 6.30 & 6.90 & 8.80 & 1.50 & 2.80 \\
\hline $\mathrm{MgO}$ & 3.98 & 3.01 & 2.89 & 3.79 & 6.48 & 1.31 & 2.82 \\
\hline $\mathrm{CaO}$ & 6.46 & 6.52 & 7.15 & 8.03 & 8.60 & 4.59 & 5.24 \\
\hline $\mathrm{Na}_{2} \mathrm{O}$ & 4.73 & 5.60 & 5.57 & 3.46 & 3.60 & 4.91 & 7.42 \\
\hline $\mathrm{K}_{2} \mathrm{O}$ & 1.31 & 1.24 & 1.42 & .85 & .70 & 1.02 & .55 \\
\hline $\mathrm{P}_{2} \mathrm{O}_{5} \ldots \ldots \ldots \ldots \ldots \ldots$ & .39 & .22 & .47 & .25 & .26 & .13 & .63 \\
\hline $\mathrm{MnO}$ & .14 & .12 & .13 & .15 & .17 & .06 & .03 \\
\hline 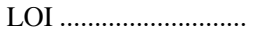 & .06 & .47 & .31 & .23 & .31 & .60 & .30 \\
\hline 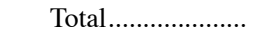 & 100.01 & 99.25 & 99.94 & 100.80 & 99.50 & 99.19 & 99.10 \\
\hline \multicolumn{8}{|c|}{ Trace elements, in parts per million } \\
\hline 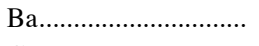 & 530 & 170 & 920 & 190 & 270 & 890 & 80 \\
\hline $\mathrm{Cr}$ & 40 & 40 & 37 & 30 & 270 & 30 & NA \\
\hline $\mathrm{Nb}$ & 20 & 20 & 40 & 10 & 20 & $<10$ & 20 \\
\hline $\mathrm{Rb}$ & 20 & 20 & 30 & 20 & 20 & $<10$ & 10 \\
\hline $\mathrm{Sr}$ & 910 & 680 & 940 & 420 & 400 & 1,590 & 580 \\
\hline $\mathrm{Y}$ & 20 & 30 & 20 & 40 & 20 & $<10$ & 30 \\
\hline $\mathrm{Zr}$ & 140 & 100 & 220 & 210 & 90 & 40 & 260 \\
\hline \multicolumn{8}{|c|}{ CIPW norms, in weight percent } \\
\hline 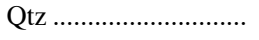 & 7.14 & 1.27 & - & 9.61 & - & 23.50 & - \\
\hline 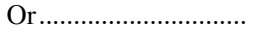 & 7.74 & 7.33 & 8.39 & 5.02 & 4.14 & 6.03 & 3.25 \\
\hline $\mathrm{Ab}$ & 40.02 & 47.39 & 47.13 & 29.28 & 30.46 & 41.55 & 62.79 \\
\hline An & 19.10 & 23.59 & 18.01 & 27.80 & 23.52 & 18.88 & 13.91 \\
\hline $\mathrm{C}$ & - & - & - & - & - & - & - \\
\hline Di & 8.38 & 5.95 & 11.96 & 8.61 & 14.30 & 2.45 & 6.27 \\
\hline 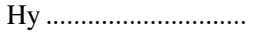 & 10.05 & 8.89 & 4.28 & 14.64 & 17.35 & 3.33 & 4.32 \\
\hline $\mathrm{Ol}$ & - & - & 3.77 & - & 2.91 & - & .38 \\
\hline Mt & 4.67 & 2.68 & 2.25 & 2.99 & 2.90 & 2.00 & 3.89 \\
\hline Il & 1.94 & 1.18 & 2.75 & 2.05 & 3.00 & .55 & 2.53 \\
\hline Ap & .90 & .51 & 1.09 & .58 & .60 & .30 & 1.46 \\
\hline 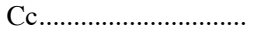 & - & - & - & - & - & - & - \\
\hline
\end{tabular}




\section{Sample Descriptions and Collection Localities - Table 3}

746-Medium-grained, weakly foliated hypersthene tonalite. Northeast side of small, unnamed pond, 1 mi east-northeast of north end of Hoot Owl Lake; Newfoundland 7.5-min quadrangle.

114-Garnetiferous hypersthene diorite. Intercalated with thin hornblende-plagioclase amphibolite layers. Westbound U.S. Route 46, 1,900 ft northwest of intersection with New Jersey Route 10, Ledgewood; Stanhope 7.5-min quadrangle.

108-Quartz-hypersthene diorite. South side of Lawrence Road, 0.9 mi southwest of intersection of Mill Brook Avenue and New Jersey Route 10; Mendham 7.5-min quadrangle.

31-Homogeneous hypersthene tonalite. East side of Watnong Mountain, $0.58 \mathrm{mi}$ west of intersection of powerline and Tabor Road; Morristown 7.5-min quadrangle.

561 -Hypersthene diorite. West side of ridge, east of Macopin Road, 0.35 mi south-southwest of Hillcrest School; Newfoundland 7.5-min quadrangle.

603-Hypersthene diorite. East side of Germantown Road, $0.3 \mathrm{mi}$ north of intersection with northbound New Jersey Route 23; Newfoundland 7.5-min quadrangle.

43 - Hypersthene diorite. North side of ridge, north of Butler Reservoir, 1,600 ft east of Kinnelon High School; Pompton Plains 7.5-min quadrangle.
219-Hypersthene diorite. Draw in ridge west of Wanaque Reservoir, 0.46 mi southeast of intersection of West Brook and Stonetown Roads; Wanaque 7.5-min quadrangle.

80-Hypersthene diorite. West side of ridge, north of powerline, 0.4 mi southwest of intersection of Beech Road and New Jersey Route 511; Greenwood Lake 7.5-min quadrangle.

W172-Hypersthene diorite. Southeast side of ridge, north of Canistear Reservoir, 0.5 mi southwest of intersection of unimproved road and Canistear Road; Wawayanda 7.5-min quadrangle.

68-Hypersthene diorite. Eastbound Interstate-80, $0.43 \mathrm{mi}$ east of Mt. Hope Avenue, Dover 7.5-min quadrangle.

H381 - Hypersthene diorite. East side of Central Railroad of New Jersey tracks, approximately 1,000 ft north of powerline, west of South Branch Raritan River; High Bridge 7.5-min quadrangle.

18-Hypersthene tonalite. North side of ridge, south of Stone House Brook, 0.46 mi west-northwest of northwest end of Butler Reservoir; Boonton 7.5-min quadrangle.

73-Massive-textured, weakly foliated, light-gray hypersthene diorite. East side of Lamington River, $50 \mathrm{ft}$ north of confluence with small tributary drainage, $0.81 \mathrm{mi}$ south of intersection of New Jersey Route 24 and Parker Road; Chester 7.5-min quadrangle. 
Table 4. Major-oxide and trace-element concentrations and CIPW norms of potassium-feldspar gneiss (Yk) and monazite gneiss (Ymg), New Jersey Highlands.

[Analyses by X-ray fluorescence spectrometry except that $\mathrm{FeO}$ contents were determined by potentiometric titration (Jackson and others, 1987). Analyses by XRAL Activation Services, Ann Arbor, Mich., for all samples but one; analysis of sample B40 by U.S. Geological Survey, Reston, Va. NA, not analyzed. Sample localities are described following this table]

\begin{tabular}{|c|c|c|c|c|c|c|c|c|}
\hline & \multicolumn{8}{|c|}{ Potassium-feldspar gneiss (Yk) } \\
\hline & B40 & 117 & 21 & 16 & W81 & H5 & 26 & 165 \\
\hline \multicolumn{9}{|c|}{ Major oxides and loss on ignition (LOI), in weight percent } \\
\hline $\mathrm{SiO}_{2} \ldots \ldots \ldots \ldots \ldots \ldots \ldots \ldots$ & 75.10 & 74.40 & 74.90 & 74.50 & 73.70 & 73.30 & 72.80 & 80.30 \\
\hline $\mathrm{TiO}_{2} \ldots \ldots \ldots \ldots \ldots \ldots \ldots \ldots \ldots$ & .29 & .27 & .18 & .26 & .17 & .35 & .28 & .11 \\
\hline $\mathrm{Al}_{2} \mathrm{O}_{3} \ldots \ldots \ldots \ldots \ldots \ldots \ldots \ldots \ldots \ldots \ldots \ldots$ & 12.20 & 12.90 & 11.60 & 11.90 & 13.60 & 11.30 & 14.10 & 10.70 \\
\hline $\mathrm{Fe}_{2} \mathrm{O}_{3} \ldots \ldots \ldots \ldots \ldots$ & 1.95 & 1.48 & 1.69 & 2.78 & 1.09 & 1.85 & .96 & .20 \\
\hline $\mathrm{FeO}$ & 1.10 & .70 & 1.30 & .90 & .90 & 3.11 & 1.40 & $<.10$ \\
\hline $\mathrm{MgO}$ & .19 & .41 & .58 & .12 & .24 & .58 & .36 & .05 \\
\hline $\mathrm{CaO}$ & .70 & 1.18 & 3.07 & .27 & 1.48 & .29 & 1.49 & .09 \\
\hline $\mathrm{Na}_{2} \mathrm{O}$ & 4.09 & 3.55 & 3.11 & 3.02 & 3.69 & 2.70 & 3.64 & 1.30 \\
\hline $\mathrm{K}_{2} \mathrm{O}$ & 3.62 & 4.63 & 1.56 & 5.79 & 4.36 & 5.84 & 4.79 & 7.01 \\
\hline $\mathrm{P}_{2} \mathrm{O}_{5}$ & .04 & .06 & .02 & .03 & .05 & .02 & .06 & .03 \\
\hline $\mathrm{MnO}$ & .01 & .03 & .08 & .03 & .06 & .09 & .05 & $<.01$ \\
\hline LOI & .24 & .54 & .47 & .23 & .16 & .31 & .47 & .18 \\
\hline Total ....................... & 99.53 & 100.15 & 98.56 & 99.83 & 99.50 & 99.74 & 100.40 & $<100.08$ \\
\hline \multicolumn{9}{|c|}{ Trace elements, in parts per million } \\
\hline $\mathrm{Ba}$ & NA & 670 & 1,000 & 690 & 630 & 540 & 1,100 & 610 \\
\hline $\mathrm{Cr}$ & NA & 20 & 10 & 23 & 10 & 40 & 23 & NA \\
\hline $\mathrm{Nb}$ & NA & 20 & $<10$ & 40 & 10 & 20 & 10 & 10 \\
\hline $\mathrm{Rb}$ & NA & 160 & 50 & 120 & 230 & 180 & 200 & 200 \\
\hline $\mathrm{Sr}$ & NA & 110 & 60 & 30 & 110 & $<10$ & 250 & 60 \\
\hline $\mathrm{Y}$ & NA & 30 & 20 & 80 & 20 & 70 & 20 & 30 \\
\hline $\mathrm{Zr}$ & NA & 150 & 130 & 780 & 150 & 700 & 230 & 190 \\
\hline \multicolumn{9}{|c|}{ CIPW norms, in weight percent } \\
\hline Qtz............................. & 35.78 & 33.06 & 43.50 & 34.10 & 31.89 & 32.10 & 29.09 & 45.73 \\
\hline 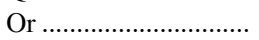 & 21.39 & 27.36 & 9.22 & 34.22 & 25.77 & 34.51 & 28.31 & 41.43 \\
\hline $\mathrm{Ab}$ & 34.61 & 30.04 & 26.32 & 25.55 & 31.22 & 22.85 & 30.80 & 11.00 \\
\hline 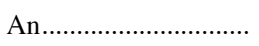 & 3.21 & 5.46 & 13.09 & 1.14 & 7.02 & 1.31 & 7.00 & .25 \\
\hline $\mathrm{C}$ & .38 & .05 & - & .25 & .24 & .06 & .36 & .88 \\
\hline $\mathrm{Di}$ & - & - & 1.64 & - & - & - & - & - \\
\hline 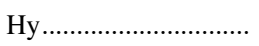 & .47 & 1.02 & 1.49 & .30 & 1.18 & 5.22 & 2.30 & .12 \\
\hline Mt ............................. & 2.74 & 1.57 & 2.45 & 2.24 & 1.58 & 2.68 & 1.39 & - \\
\hline 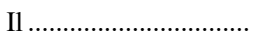 & .55 & .51 & .34 & .49 & .32 & .66 & .53 & - \\
\hline 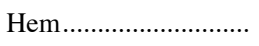 & .06 & .40 & - & 1.23 & - & - & - & .20 \\
\hline Аp & .09 & .14 & .05 & .07 & .12 & .05 & .14 & .07 \\
\hline $\mathrm{Ru}$ & - & - & - & - & - & - & - & .11 \\
\hline
\end{tabular}


Table 4. Major-oxide and trace-element concentrations and CIPW norms of potassium-feldspar gneiss (Yk) and monazite gneiss (Ymg), New Jersey Highlands - Continued.

\begin{tabular}{|c|c|c|c|c|c|c|c|c|}
\hline & \multicolumn{6}{|c|}{ Potassium-feldspar gneiss (Yk) - Continued } & \multicolumn{2}{|c|}{$\begin{array}{l}\text { Monazite gneiss } \\
\quad(Y m g)\end{array}$} \\
\hline & 530 & 91 & 352 & G159 & 340 & 415 & $\mathrm{C} 81$ & 19 \\
\hline \multicolumn{9}{|c|}{ Major oxides and loss on ignition (LOI), in weight percent } \\
\hline 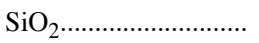 & 77.50 & 72.30 & 63.80 & 68.90 & 72.60 & 73.60 & 72.00 & 72.40 \\
\hline $\mathrm{TiO}_{2} \ldots \ldots \ldots \ldots \ldots \ldots \ldots \ldots$ & .27 & .49 & .53 & .30 & .18 & .32 & .28 & .27 \\
\hline $\mathrm{Al}_{2} \mathrm{O}_{3} \ldots \ldots \ldots \ldots \ldots \ldots \ldots \ldots$ & 10.50 & 12.40 & 15.90 & 16.10 & 13.80 & 13.30 & 13.80 & 11.20 \\
\hline $\mathrm{Fe}_{2} \mathrm{O}_{3} \ldots \ldots \ldots$ & 1.72 & 2.94 & 3.41 & 1.03 & .45 & 1.59 & 2.00 & 2.56 \\
\hline $\mathrm{FeO}$ & .40 & 1.80 & 3.30 & .80 & 1.20 & .90 & 1.00 & 3.90 \\
\hline $\mathrm{MgO}$ & .45 & .82 & .48 & .75 & .77 & .44 & .37 & .12 \\
\hline $\mathrm{CaO}$ & .21 & .77 & 1.20 & 2.55 & 2.28 & 2.20 & 1.05 & 1.97 \\
\hline $\mathrm{Na}_{2} \mathrm{O}$ & 1.58 & 2.77 & 2.81 & 4.99 & 2.71 & 2.93 & 2.90 & 2.42 \\
\hline $\mathrm{K}_{2} \mathrm{O}$ & 5.53 & 4.76 & 7.30 & 3.69 & 4.83 & 4.13 & 5.32 & 4.45 \\
\hline $\mathrm{P}_{2} \mathrm{O}_{5}$ & .07 & .09 & .12 & .10 & .05 & .07 & .06 & .04 \\
\hline $\mathrm{MnO}$ & .02 & .05 & .20 & .03 & .03 & .03 & .03 & .06 \\
\hline LOI............................... & .85 & .47 & .50 & .62 & .47 & .39 & 1.16 & .54 \\
\hline Total ........................ & 99.10 & 99.66 & 99.55 & 99.86 & 99.37 & 99.90 & 99.97 & 99.93 \\
\hline \multicolumn{9}{|c|}{ Trace elements, in parts per million } \\
\hline $\mathrm{Ba}$ & 980 & 960 & 1,100 & 750 & 410 & 1,000 & 630 & 350 \\
\hline $\mathrm{Cr}$ & 70 & 50 & 40 & 20 & 10 & 20 & 21 & 10 \\
\hline 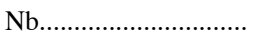 & 50 & 40 & 40 & $<10$ & $<10$ & $<10$ & 20 & 80 \\
\hline $\mathrm{Rb}$ & 190 & 150 & 210 & 110 & 150 & 130 & 240 & 150 \\
\hline $\mathrm{Sr}$ & 60 & 170 & 160 & 560 & 270 & 350 & 110 & 60 \\
\hline $\mathrm{Y}$ & 150 & 80 & 100 & $<10$ & 10 & 20 & 70 & 240 \\
\hline $\mathrm{Zr}$ & 190 & 480 & 1,100 & 160 & 100 & 260 & 290 & 660 \\
\hline \multicolumn{9}{|c|}{ CIPW norms, in weight percent } \\
\hline 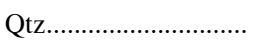 & 46.22 & 35.28 & 15.32 & 19.66 & 31.73 & 35.58 & 32.14 & 35.50 \\
\hline 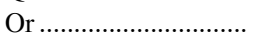 & 32.68 & 28.13 & 43.14 & 21.81 & 28.54 & 24.41 & 31.44 & 26.30 \\
\hline $\mathrm{Ab}$ & 13.37 & 23.44 & 23.78 & 42.22 & 22.93 & 24.79 & 24.54 & 20.48 \\
\hline An.................................. & .58 & 3.23 & 5.17 & 10.64 & 10.98 & 10.46 & 4.82 & 6.56 \\
\hline С & 1.70 & 1.51 & 1.48 & - & .09 & .18 & 1.51 & - \\
\hline $\mathrm{Di}$ & - & - & - & 1.07 & - & - & - & 2.61 \\
\hline Ну & 1.12 & 2.20 & 3.93 & 1.54 & 3.51 & 1.10 & .92 & 3.64 \\
\hline Mt.................................. & .57 & 4.26 & 4.94 & 1.49 & .65 & 2.07 & 2.51 & 3.71 \\
\hline Il ..................................... & .51 & .93 & 1.01 & .57 & .34 & .61 & .53 & .51 \\
\hline 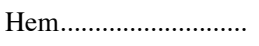 & 1.33 & - & - & - & - & .16 & .27 & - \\
\hline Ар & .16 & .21 & .28 & .23 & .12 & .16 & .14 & .09 \\
\hline $\mathrm{Ru}$ & - & - & - & - & - & - & - & - \\
\hline
\end{tabular}




\section{Sample Descriptions and Collection Localities-Table 4}

B40-Medium-grained, foliated plagioclase-K-feldspar-quartz gneiss. East side of Stony Brook Mountains, $0.96 \mathrm{mi}$ north-northeast of dam, Taylortown Reservoir; Boonton 7.5-min quadrangle.

117-Biotite-plagioclase-K-feldspar-quartz gneiss. Southeast of unnamed pond, $0.85 \mathrm{mi}$ north of intersection of Fairview Avenue and Stony Brook; Hackettstown 7.5-min quadrangle.

21-Garnet-biotite-K-feldspar-plagioclase-quartz gneiss. South side of West Hanover Avenue, 1,200 ft west of intersection with Gaston Road; Mendham 7.5-min quadrangle.

16-Plagioclase-K-feldspar-quartz gneiss. Ridge crest, $0.34 \mathrm{mi}$ west-southwest of intersection of New Jersey Route 517 and Ketchum Road; Tranquility 7.5-min quadrangle.

W81-Garnet-plagioclase-K-feldspar-quartz gneiss. East side of intersection of Weaver and Otter Hole Roads; Wanaque 7.5-min quadrangle.

H5-Sillimanite-garnet-biotite-plagioclase-K-feldspar-quartz gneiss. West side of Mt. Kipp, Lentine Aggregates Quarry, Glen Gardner; High Bridge 7.5-min quadrangle.

26-Garnet-plagioclase-K-feldspar-quartz gneiss. West side of ridge, 0.34 mi south of intersection of Sloatsburg Road and New York State border; Sloatsburg 7.5-min quadrangle.

165-Homogeneous plagioclase-K-feldspar-quartz gneiss. Pochuck Mountain, $0.43 \mathrm{mi}$ due east of intersection of Wallkill Road and Glenwood Mountain Road; Unionville 7.5-min quadrangle.

530-Biotite-plagioclase-K-feldspar-quartz gneiss. County House Mountain, 0.56 mi north of intersection of Pohatcong Creek and Valley Road; Washington 7.5-min quadrangle.
91-Biotite-plagioclase-K-feldspar-quartz gneiss. Jenny Jump Mountain, 0.80 mi north of intersection of Shades of Death Road and New Jersey Route 611; Blairstown 7.5-min quadrangle.

352-Garnet-biotite-plagioclase-quartz-K-feldspar gneiss. Hamburg Mountain, northeast of small pond, $0.35 \mathrm{mi}$ southeast of intersection of New Jersey Routes 94 and 517; Hamburg 7.5-min quadrangle.

G159-K-feldspar-plagioclase-quartz gneiss. South of ridge crest, 0.37 mi east of intersection of Wanaque River and New Jersey Route 511; Greenwood Lake 7.5-min quadrangle.

340 - Biotite-plagioclase-K-feldspar-quartz gneiss. Southwest of intersection of powerlines, $1,250 \mathrm{ft}$ west-northwest of intersection of Sussex Turnpike and Ironia Road; Mendham 7.5-min quadrangle.

415-Hornblende-plagioclase-K-feldspar-quartz gneiss. East side of ridge, $650 \mathrm{ft}$ west-northwest of north end of Lake Sonoma; Wanaque 7.5-min quadrangle.

C81-Medium-grained, strongly lineated monazite-biotite-plagioclase-K-feldspar-quartz gneiss. East side of Tanners Brook, 0.46 mi southwest of intersection of New Jersey Route 24 and East Valley Brook Road; Chester 7.5-min quadrangle.

19-Medium-grained, foliated monazite-hornblende-plagioclaseK-feldspar-quartz gneiss. Along Indian Grove Brook, intersection of Hardscrabble and Lloyd Roads; Bernardsville 7.5-min quadrangle. 
Table 5. Major-oxide and trace-element concentrations and CIPW norms of microcline gneiss (Ym), New Jersey Highlands.

[Analyses by X-ray fluorescence spectrometry except that $\mathrm{FeO}$ contents were determined by potentiometric titration (Jackson and others, 1987). Analyses by XRAL Activation Services, Ann Arbor, Mich. Sample localities are described below]

\begin{tabular}{|c|c|c|c|c|c|}
\hline & 155 & 1020 & 72 & W8 & 51 \\
\hline \multicolumn{6}{|c|}{ Major oxides and loss on ignition (LOI), in weight percent } \\
\hline 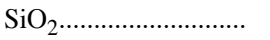 & 73.00 & 74.20 & 73.80 & 71.90 & 77.00 \\
\hline $\mathrm{TiO}_{2}$ & .36 & .12 & .17 & .16 & .23 \\
\hline $\mathrm{Al}_{2} \mathrm{O}_{3} \ldots \ldots \ldots \ldots \ldots \ldots \ldots \ldots$ & 12.50 & 12.10 & 12.80 & 12.70 & 10.40 \\
\hline $\mathrm{Fe}_{2} \mathrm{O}_{3} \ldots \ldots \ldots \ldots \ldots \ldots \ldots$ & 2.56 & .70 & 1.57 & 2.39 & 2.52 \\
\hline $\mathrm{FeO}$ & 1.90 & .80 & .10 & 1.40 & .80 \\
\hline $\mathrm{MgO}$ & 1.04 & .75 & .18 & 1.22 & .12 \\
\hline $\mathrm{CaO}$ & 1.27 & .69 & .57 & .39 & .08 \\
\hline $\mathrm{Na}_{2} \mathrm{O} \ldots \ldots \ldots \ldots \ldots \ldots \ldots \ldots$ & 1.58 & .75 & 4.01 & 3.41 & .84 \\
\hline $\mathrm{K}_{2} \mathrm{O} \ldots \ldots \ldots \ldots \ldots \ldots$ & 5.18 & 7.45 & 5.08 & 6.40 & 7.47 \\
\hline $\mathrm{P}_{2} \mathrm{O}_{5} \ldots \ldots \ldots \ldots \ldots \ldots$ & .07 & .03 & .03 & .03 & .02 \\
\hline $\mathrm{MnO}$ & .04 & .05 & .01 & .01 & .07 \\
\hline 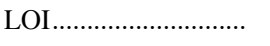 & .77 & 1.16 & .85 & .31 & .31 \\
\hline Total....................... & 100.27 & 98.80 & 99.17 & 100.32 & 99.86 \\
\hline \multicolumn{6}{|c|}{ Trace elements, in parts per million } \\
\hline $\mathrm{Ba}$ & 640 & 1,500 & 1,600 & 890 & 1,800 \\
\hline $\mathrm{Cr}$ & 20 & 20 & 30 & 21 & 21 \\
\hline $\mathrm{Nb}$ & 30 & 20 & $<10$ & 10 & 30 \\
\hline $\mathrm{Rb}$ & 130 & 140 & 160 & 220 & 220 \\
\hline $\mathrm{Sr}$ & 70 & 70 & 110 & 150 & 90 \\
\hline Y & 90 & 50 & 30 & 40 & 140 \\
\hline $\mathrm{Zr}$ & 390 & 170 & 200 & 170 & 1,000 \\
\hline \multicolumn{6}{|c|}{ CIPW norms, in weight percent } \\
\hline Qtz............................ & 39.52 & 38.45 & 29.78 & 25.12 & 43.23 \\
\hline $\mathrm{Or}$ & 30.61 & 44.03 & 30.20 & 37.82 & 44.15 \\
\hline $\mathrm{Ab}$ & 13.37 & 6.35 & 33.93 & 28.85 & 7.11 \\
\hline An & 5.84 & 3.23 & 1.92 & .45 & .27 \\
\hline $\mathrm{C}$ & 2.15 & 1.62 & - & - & .84 \\
\hline $\mathrm{Di}$ & - & - & .42 & 1.02 & - \\
\hline 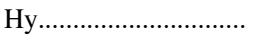 & 3.44 & 2.65 & .25 & 2.91 & .30 \\
\hline Mt & 3.71 & 1.01 & - & 3.47 & 2.14 \\
\hline Il & .68 & .23 & .23 & .30 & .44 \\
\hline Hem & - & - & 1.57 & - & 1.04 \\
\hline Ti ................................ & - & - & .12 & - & - \\
\hline 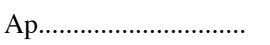 & .16 & .07 & .07 & .07 & .05 \\
\hline
\end{tabular}

\section{Sample Descriptions and Collection Localities-Table 5}

155-Medium-fine- to medium-grained, well-layered sillimanitegarnet-biotite-plagioclase-quartz-K-feldspar gneiss. Sand and gravel pit, east side of New Jersey Route 517, 0.45 mi west of west end of Rocker Pond; Stanhope 7.5-min quadrangle.

1020 - Layered garnet-biotite-quartz-K-feldspar gneiss. West side of Houses Corners Road, 0.56 mi south of Woodruffs Gap; Newton East 7.5-min quadrangle.

72-Biotite-plagioclase-K-feldspar-quartz gneiss. Bowling Green Mountain, 0.72 mi northeast of south end of Lake Swannanoa; Franklin 7.5-min quadrangle.
W8-Layered hornblende-biotite-plagioclase-quartz-K-feldspar gneiss. East side of Canistear Road, 0.21 mi north of intersection with Cherry Ridge Brook; Wawayanda 7.5-min quadrangle.

51-Sillimanite-biotite-plagioclase-K-feldspar-quartz gneiss. North side of private road, Panther Valley, $0.50 \mathrm{mi}$ west-northwest of south end of Allamuchy Pond; Tranquility 7.5-min quadrangle. 
Table 6. Major-oxide and trace-element concentrations and CIPW norms of biotite-quartz-feldspar gneiss (Yb), New Jersey Highlands.

[Analyses by X-ray fluorescence spectrometry except that FeO contents were determined by potentiometric titration (Jackson and others, 1987). Analyses by XRAL Activation Services, Ann Arbor, Mich., for all samples but two; analyses of samples G13 and D2 by U.S. Geological Survey, Reston, Va. NA, not analyzed. Sample localities are described following this table]

\begin{tabular}{|c|c|c|c|c|c|c|c|c|c|c|c|}
\hline & \multicolumn{11}{|c|}{ Rusty-weathering } \\
\hline & G13 & T42 & H65 & 130 & C79 & 115 & M1 & 71 & 192 & $\mathrm{P} 2$ & 44 \\
\hline \multicolumn{12}{|c|}{ Major oxides and loss on ignition (LOI), in weight percent } \\
\hline $\mathrm{SiO}_{2} \ldots \ldots \ldots \ldots \ldots \ldots \ldots$ & 72.90 & 52.80 & 66.60 & 54.90 & 88.60 & 71.20 & 82.60 & 70.90 & 77.50 & 72.50 & 66.40 \\
\hline $\mathrm{TiO}_{2} \ldots \ldots \ldots \ldots \ldots \ldots \ldots$ & .27 & 1.32 & 1.16 & 1.13 & .34 & .68 & .59 & 0.66 & .19 & .82 & .56 \\
\hline $\mathrm{Al}_{2} \mathrm{O}_{3} \ldots \ldots \ldots \ldots \ldots$ & 13.70 & 19.70 & 14.80 & 23.40 & 5.20 & 14.20 & 7.98 & 13.20 & 11.80 & 13.30 & 16.50 \\
\hline $\mathrm{Fe}_{2} \mathrm{O}_{3} \ldots \ldots$ & 1.60 & 6.20 & 2.47 & 2.45 & .60 & 1.02 & 1.39 & 1.98 & .79 & 1.84 & .68 \\
\hline $\mathrm{FeO}$ & .80 & 5.90 & 4.10 & 2.80 & .80 & 2.30 & 1.50 & 2.80 & .80 & 3.80 & 1.90 \\
\hline $\mathrm{MgO}$ & .59 & .71 & 1.57 & 2.11 & .55 & 1.36 & 1.07 & 1.43 & .51 & 1.57 & 2.00 \\
\hline $\mathrm{CaO}$ & 1.10 & 1.53 & 3.24 & .51 & .18 & 2.85 & 1.15 & 1.72 & 1.32 & .47 & 4.35 \\
\hline $\mathrm{Na}_{2} \mathrm{O}$ & 3.50 & .89 & 2.83 & 2.48 & .61 & 3.38 & 1.48 & 2.18 & 3.25 & .73 & 4.42 \\
\hline $\mathrm{K}_{2} \mathrm{O}$ & 4.20 & 9.05 & 2.46 & 7.39 & 1.78 & 2.27 & 1.26 & 4.06 & 3.17 & 3.76 & 1.66 \\
\hline $\mathrm{P}_{2} \mathrm{O}_{5} \ldots \ldots \ldots \ldots \ldots$ & .10 & .60 & .49 & .08 & .03 & .10 & .04 & .07 & .03 & .05 & .41 \\
\hline $\mathrm{MnO}$ & .02 & .49 & .09 & .03 & .03 & .03 & .03 & .19 & .01 & .05 & .02 \\
\hline LOI & 1.06 & 1.00 & .31 & 1.93 & .85 & .62 & .85 & .62 & .70 & 1.00 & .77 \\
\hline Total ...................... & 99.84 & 100.19 & 100.12 & 99.21 & 99.57 & 100.01 & 99.94 & 99.81 & 100.07 & 99.89 & 99.67 \\
\hline \multicolumn{12}{|c|}{ Trace elements, in parts per million } \\
\hline $\mathrm{Ba}$ & NA & 930 & 450 & 1,000 & 520 & 410 & 350 & 790 & 920 & 890 & 290 \\
\hline $\mathrm{Cr}$ & NA & $<10$ & 30 & 90 & 30 & 40 & 50 & 50 & 10 & 70 & 50 \\
\hline $\mathrm{Nb}$ & NA & 20 & 20 & 30 & $<10$ & 20 & 10 & $<10$ & $<10$ & 20 & 10 \\
\hline $\mathrm{Rb}$ & NA & 350 & 120 & 230 & 60 & 120 & 60 & 140 & 110 & 120 & 90 \\
\hline $\mathrm{Sr}$ & NA & 140 & 180 & 120 & 90 & 330 & 100 & 180 & 260 & 100 & 390 \\
\hline $\mathrm{Y}$ & NA & 70 & 50 & 120 & 30 & 10 & 40 & 40 & $<10$ & 50 & 40 \\
\hline $\mathrm{Zr}$ & NA & 490 & 310 & 300 & 190 & 260 & 370 & 260 & 150 & 260 & 90 \\
\hline \multicolumn{12}{|c|}{ CIPW norms, in weight percent } \\
\hline 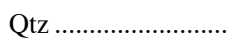 & 33.51 & 8.32 & 31.12 & 7.58 & 76.91 & 33.94 & 64.91 & 35.80 & 42.72 & 48.75 & 22.26 \\
\hline 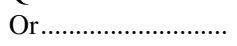 & 24.82 & 53.48 & 14.54 & 43.67 & 10.52 & 13.42 & 7.45 & 23.99 & 18.73 & 22.22 & 9.81 \\
\hline $\mathrm{Ab}$ & 29.62 & 7.53 & 23.95 & 20.99 & 5.16 & 28.60 & 12.52 & 18.45 & 27.50 & 6.18 & 37.40 \\
\hline An & 4.80 & 3.67 & 12.87 & 2.01 & .70 & 13.49 & 5.44 & 8.08 & 6.35 & 2.01 & 18.90 \\
\hline $\mathrm{C}$ & 1.64 & 7.10 & 2.76 & 10.59 & 2.01 & 1.24 & 2.19 & 2.26 & .69 & 7.29 & .51 \\
\hline 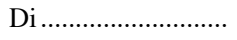 & - & - & - & - & - & - & - & - & - & - & - \\
\hline Ну & 1.47 & 6.21 & 7.65 & 6.56 & 1.84 & 5.70 & 3.35 & 6.33 & 1.79 & 8.11 & 7.02 \\
\hline Mt & 1.86 & 8.99 & 3.58 & 3.55 & .87 & 1.48 & 2.02 & 2.87 & 1.15 & 2.67 & .99 \\
\hline 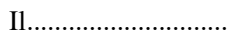 & .51 & 2.51 & 2.20 & 2.15 & .65 & 1.29 & 1.12 & 1.25 & .36 & 1.56 & 1.06 \\
\hline Hem & .32 & - & - & - & - & - & - & - & - & - & - \\
\hline Ap & .23 & 1.39 & 1.14 & .19 & .07 & .23 & .09 & .16 & .07 & .12 & .95 \\
\hline
\end{tabular}


Table 6. Major-oxide and trace-element concentrations and CIPW norms of biotite-quartzfeldspar gneiss (Yb), New Jersey Highlands - Continued.

\begin{tabular}{|c|c|c|c|c|c|c|c|}
\hline & \multicolumn{7}{|c|}{ Pinkish-gray-weathering } \\
\hline & GL13 & WQ311 & 12 & D2 & 333 & 30 & 4 \\
\hline \multicolumn{8}{|c|}{ Major oxides and loss on ignition (LOI), in weight percent } \\
\hline $\mathrm{SiO}_{2} \ldots \ldots \ldots \ldots \ldots \ldots \ldots$ & 67.60 & 67.00 & 64.30 & 76.60 & 75.30 & 65.90 & 67.90 \\
\hline $\mathrm{TiO}_{2} \ldots \ldots \ldots \ldots \ldots \ldots \ldots$ & .71 & .67 & .86 & .45 & .49 & .72 & .49 \\
\hline $\mathrm{Al}_{2} \mathrm{O}_{3} \ldots \ldots \ldots \ldots \ldots \ldots$ & 13.80 & 13.70 & 16.30 & 13.10 & 11.30 & 16.10 & 13.80 \\
\hline $\mathrm{Fe}_{2} \mathrm{O}_{3} \ldots \ldots \ldots \ldots \ldots \ldots$ & 2.53 & 3.93 & 3.82 & .62 & 2.40 & 1.41 & 1.87 \\
\hline $\mathrm{FeO}$ & 2.10 & 2.20 & 3.70 & .44 & 1.60 & 1.40 & 5.40 \\
\hline $\mathrm{MgO}$ & 1.86 & 1.80 & 2.86 & .29 & 1.14 & 2.61 & 1.73 \\
\hline $\mathrm{CaO}$ & 2.00 & .66 & 2.06 & .61 & 1.44 & 1.66 & 1.18 \\
\hline $\mathrm{Na}_{2} \mathrm{O}$ & 3.34 & 3.76 & 2.77 & 3.40 & 2.59 & 6.37 & 2.49 \\
\hline $\mathrm{K}_{2} \mathrm{O} \ldots \ldots \ldots \ldots \ldots$ & 4.34 & 5.43 & 3.15 & 4.20 & 2.98 & 3.32 & 3.84 \\
\hline $\mathrm{P}_{2} \mathrm{O}_{5}$ & .18 & .10 & .08 & .02 & .10 & .13 & .06 \\
\hline $\mathrm{MnO}$ & .02 & .01 & .04 & .01 & .08 & .01 & .17 \\
\hline LOI & .54 & .47 & .47 & .75 & .47 & .31 & .14 \\
\hline Total ...................... & 99.02 & 99.73 & $\overline{100.41}$ & 100.49 & $\overline{99.89}$ & $\overline{99.94}$ & 99.07 \\
\hline \multicolumn{8}{|c|}{ Trace elements, in parts per million } \\
\hline 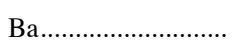 & 710 & 610 & 570 & NA & 880 & 440 & 1,200 \\
\hline $\mathrm{Cr}$ & 70 & 70 & 89 & NA & 110 & 84 & 20 \\
\hline $\mathrm{Nb}$ & $<10$ & 30 & $<10$ & NA & 30 & 20 & 20 \\
\hline $\mathrm{Rb}$ & 160 & 180 & 150 & NA & 120 & 130 & 130 \\
\hline $\mathrm{Sr}$ & 120 & 30 & 90 & NA & 150 & 100 & 100 \\
\hline $\mathrm{Y}$ & 10 & 30 & 50 & NA & 40 & 60 & 30 \\
\hline $\mathrm{Zr}$ & 180 & 170 & 210 & NA & 250 & 200 & 140 \\
\hline \multicolumn{8}{|c|}{ CIPW norms, in weight percent } \\
\hline Qtz ........................... & 24.72 & 20.53 & 26.64 & 39.06 & 44.19 & 9.35 & 30.19 \\
\hline 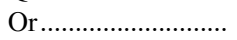 & 25.65 & 32.09 & 18.62 & 24.82 & 17.61 & 19.62 & 22.69 \\
\hline $\mathrm{Ab}$ & 28.26 & 31.82 & 23.44 & 28.77 & 21.92 & 53.90 & 21.07 \\
\hline 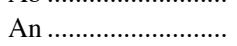 & 8.75 & 2.62 & 9.70 & 2.90 & 6.49 & 5.53 & 5.46 \\
\hline $\mathrm{C}$ & .40 & .68 & 4.78 & 1.90 & 1.44 & - & 3.55 \\
\hline Di & - & - & - & - & - & 1.45 & - \\
\hline 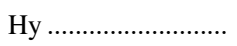 & 5.26 & 4.48 & 9.42 & .72 & 3.13 & 6.06 & 12.19 \\
\hline 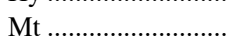 & 3.67 & 5.18 & 5.54 & .15 & 3.48 & 2.04 & 2.71 \\
\hline Il ................................ & 1.35 & 1.27 & 1.63 & .85 & .93 & 1.37 & .93 \\
\hline 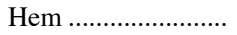 & - & .36 & - & .52 & - & - & - \\
\hline 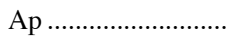 & .42 & .23 & .19 & .05 & .23 & .30 & .14 \\
\hline
\end{tabular}




\section{Sample Descriptions and Collection Localities-Table 6}

G13-Medium-to medium-coarse-grained, foliated graphite-biotite-quartz-feldspar gneiss. West side of ridge, northeast end of Ravine Lake; Gladstone 7.5-min quadrangle.

T42-Sillimanite-garnet-biotite-quartz-feldspar gneiss. North side of ridge, east of New Jersey Route 613 at Alphano; Tranquility 7.5-min quadrangle.

H65-Graphite-sillimanite-garnet-biotite-quartz-feldspar gneiss. West side of Fairmount Road, 0.80 mi north of intersection with Tanners Brook; Hackettstown 7.5-min quadrangle.

130-Graphite-sillimanite-biotite-feldspar gneiss. North side of Stephensburg Road, 0.9 mi north of Pleasant Grove; Hackettstown 7.5-min quadrangle.

C79-Graphite-biotite-feldspar-quartz gneiss. Along Frog Hollow Brook, intersection of Frog Hollow and Beavers Roads; Califon 7.5-min quadrangle.

115-Graphite-garnet-sillimanite-biotite-quartz-feldspar gneiss. Along North Branch Raritan River, 0.44 mi northeast of intersection of Willow Avenue and Hub Hollow Road; Gladstone 7.5-min quadrangle.

M1 - Graphite-biotite-feldspar-quartz gneiss. Small ridge $400 \mathrm{ft}$ west of Sunrise Lake; Mendham 7.5-min quadrangle.

71-Garnet-biotite-quartz-feldspar gneiss. West bank of Lamington River, $0.57 \mathrm{mi}$ south of intersection of New Jersey Route 24 and Hacklebarney State Park Road; Chester 7.5-min quadrangle.

192-Hornblende-biotite-quartz-feldspar gneiss. Along unnamed stream west of Hell Mountain, $0.63 \mathrm{mi}$ south of Mountainville; Califon 7.5-min quadrangle.
P2-Graphite-garnet-biotite-quartz-feldspar gneiss. West side of Matthews Avenue, $300 \mathrm{ft}$ west of north end of Suntan Lake; Pompton Plains 7.5-min quadrangle.

44-Biotite-quartz-feldspar gneiss. East side of Erie Railroad tracks. 0.16 mi west of intersection of New Jersey Route 511 and Storms Avenue; Wanaque 7.5-min quadrangle.

GL13 - Garnet-biotite-quartz-feldspar gneiss. West side of unnamed stream, north of Ringwood Avenue, $0.35 \mathrm{mi}$ northeast of powerline substation; Greenwood Lake 7.5-min quadrangle.

WQ311 - Biotite-quartz-feldspar gneiss. East side of Federal Hill, 0.50 mi north of Pompton Junction; Wanaque 7.5-min quadrangle.

12-Sillimanite-garnet-biotite-quartz-feldspar gneiss. Along powerline, $0.31 \mathrm{mi}$ east of water tower at Peters Mine, northwest of Ringwood Mill Pond; Greenwood Lake 7.5-min quadrangle.

D2-Biotite-quartz-feldspar gneiss. Northbound New Jersey Route 15, 1.2 mi north of intersection with Taylor Road; Dover 7.5-min quadrangle.

333-Sillimanite-biotite-quartz-feldspar gneiss. Oxford Mountain, west of powerline, $0.32 \mathrm{mi}$ north of Bowerstown Road; Washington 7.5-min quadrangle.

30-Biotite-quartz-feldspar gneiss. West side of ridge, approximately $300 \mathrm{ft}$ east of Burnt Meadow Road, $450 \mathrm{ft}$, south of powerline; Greenwood Lake 7.5-min quadrangle.

4-Garnet-biotite-quartz-feldspar gneiss. North side of small ridge crest, 1,400 ft north of Park Road, 1,500 ft west of Interstate-80; Morristown 7.5-min quadrangle. 
Table 7. Major-oxide and trace-element concentrations and CIPW norms of hornblende-quartz-feldspar gneiss (Ymh), New Jersey Highlands.

[Analyses by X-ray fluorescence spectrometry except that $\mathrm{FeO}$ contents were determined by potentiometric titration (Jackson and others, 1987). Analyses by XRAL Activation Services, Ann Arbor, Mich. Sample localities are described below]

\begin{tabular}{|c|c|c|c|}
\hline & 100 & WA311 & H147 \\
\hline \multicolumn{4}{|c|}{ Major oxides and loss on ignition (LOI), in weight percent } \\
\hline $\mathrm{SiO}_{2} \ldots \ldots \ldots \ldots \ldots \ldots \ldots \ldots \ldots$ & 67.70 & 68.20 & 66.10 \\
\hline $\mathrm{TiO}_{2} \ldots \ldots \ldots \ldots \ldots \ldots \ldots \ldots$ & .57 & .47 & .43 \\
\hline $\mathrm{Al}_{2} \mathrm{O}_{3} \ldots \ldots \ldots \ldots \ldots \ldots \ldots \ldots$ & 14.90 & 12.90 & 14.50 \\
\hline $\mathrm{Fe}_{2} \mathrm{O}_{3} \ldots \ldots \ldots \ldots \ldots \ldots \ldots$ & 1.55 & 3.41 & 4.40 \\
\hline $\mathrm{FeO}$ & 3.20 & 3.80 & 2.90 \\
\hline $\mathrm{MgO}$ & .39 & .30 & .22 \\
\hline $\mathrm{CaO}$ & 2.87 & 1.72 & 1.00 \\
\hline 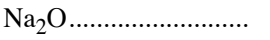 & 3.47 & 4.04 & 2.95 \\
\hline $\mathrm{K}_{2} \mathrm{O} \ldots \ldots \ldots \ldots \ldots \ldots \ldots \ldots \ldots \ldots \ldots \ldots \ldots \ldots$ & 4.91 & 5.06 & 6.63 \\
\hline $\mathrm{P}_{2} \mathrm{O}_{5} \ldots \ldots \ldots \ldots \ldots \ldots \ldots$ & .15 & .07 & .04 \\
\hline $\mathrm{MnO}$ & .06 & .11 & .29 \\
\hline 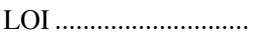 & .39 & .23 & .54 \\
\hline Total ...................... & 100.16 & 100.31 & 100.00 \\
\hline \multicolumn{4}{|c|}{ Trace elements, in parts per million } \\
\hline $\mathrm{Ba}$ & 1,400 & 410 & 440 \\
\hline $\mathrm{Cr}$ & 14 & 22 & 17 \\
\hline $\mathrm{Nb}$ & 20 & 70 & 60 \\
\hline $\mathrm{Rb}$ & 130 & 150 & 160 \\
\hline 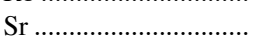 & 310 & 50 & 80 \\
\hline $\mathrm{Y}$ & 60 & 200 & 210 \\
\hline $\mathrm{Zr}$ & 650 & 930 & 1,200 \\
\hline \multicolumn{4}{|c|}{ CIPW norms, in weight percent } \\
\hline Qtz ............................. & 21.28 & 21.05 & 20.51 \\
\hline 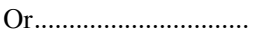 & 29.02 & 29.90 & 39.18 \\
\hline $\mathrm{Ab}$ & 29.36 & 34.19 & 24.96 \\
\hline 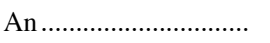 & 10.58 & 2.12 & 4.70 \\
\hline $\mathrm{C}$ & - & - & .75 \\
\hline 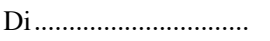 & 2.31 & 5.17 & - \\
\hline 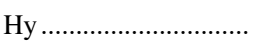 & 3.54 & 1.66 & 2.07 \\
\hline Mt ................................. & 2.25 & 4.94 & 6.38 \\
\hline Il & 1.08 & .89 & .82 \\
\hline Ap & .35 & .16 & .09 \\
\hline
\end{tabular}

\section{Sample Descriptions and Collection Localities-Table 7}

100-Medium-grained, foliated garnet-hornblende-quartz-feldspar gneiss. Along Cannonball Trail, east side of Rocky Mountain, 0.50 mi east-northeast of south end of Bear Swamp Lake; Ramsey 7.5-min quadrangle.

WA311 - Titanite-hornblende-feldspar-quartz gneiss. West side of unnamed stream, west of New Jersey Route 515, 0.50 mi west of north end of Mastodon Lake; Wawayanda 7.5-min quadrangle.

H147-Garnet-hornblende-quartz-feldspar gneiss. Northeast side of unimproved road at bend, 0.53 mi east-northeast of east end of Mud Pond; Hamburg 7.5-min quadrangle. 
Table 8. Major-oxide and trace-element concentrations and CIPW norms of clinopyroxene-quartz-feldspar gneiss (Ymp), New Jersey Highlands.

[Analyses by X-ray fluorescence spectrometry except that FeO contents were determined by potentiometric titration (Jackson and others, 1987). Analyses by XRAL Activation Services, Ann Arbor, Mich. Sample localities are described following this table]

\begin{tabular}{|c|c|c|c|c|c|c|c|c|}
\hline & 238 & 95 & S381 & 243 & WA200 & 426 & 299 & 692 \\
\hline \multicolumn{9}{|c|}{ Major oxides and loss on ignition (LOI), in weight percent } \\
\hline $\mathrm{SiO}_{2} \ldots \ldots \ldots \ldots \ldots \ldots \ldots \ldots \ldots \ldots \ldots$ & 66.30 & 74.50 & 71.80 & 60.80 & 73.80 & 74.30 & 59.40 & 70.40 \\
\hline 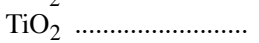 & .66 & .28 & .53 & .62 & .27 & .33 & 1.65 & .27 \\
\hline $\mathrm{Al}_{2} \mathrm{O}_{3} \ldots \ldots \ldots \ldots \ldots \ldots \ldots$ & 10.20 & 12.60 & 12.80 & 12.10 & 12.50 & 13.20 & 14.70 & 13.80 \\
\hline 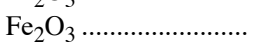 & 5.75 & 1.49 & 2.35 & 2.75 & 1.65 & 1.77 & 4.78 & 1.50 \\
\hline $\mathrm{FeO}$ & 2.80 & .90 & 1.20 & 2.70 & .60 & .30 & 3.90 & .60 \\
\hline $\mathrm{MgO}$ & 1.50 & .27 & .60 & 2.46 & .30 & .39 & 1.62 & .33 \\
\hline $\mathrm{CaO}$ & 3.87 & 1.23 & 2.01 & 6.65 & 1.06 & .43 & 4.37 & 1.45 \\
\hline $\mathrm{Na}_{2} \mathrm{O}$ & 2.00 & 3.66 & 4.02 & 1.50 & 3.86 & 5.29 & 4.74 & 3.87 \\
\hline $\mathrm{K}_{2} \mathrm{O}$ & 5.42 & 4.65 & 4.13 & 7.60 & 5.41 & 3.83 & 4.04 & 5.58 \\
\hline $\mathrm{P}_{2} \mathrm{O}_{5}$ & .14 & .06 & .10 & .17 & .05 & .04 & .48 & .09 \\
\hline $\mathrm{MnO}$ & .15 & .03 & .06 & .10 & .03 & .02 & .12 & .05 \\
\hline LOI & .70 & .31 & .08 & .85 & .08 & .54 & .31 & .20 \\
\hline Total ......................... & $\overline{99.49}$ & $\overline{99.98}$ & $\overline{99.68}$ & $\overline{98.30}$ & $\overline{99.61}$ & $\overline{100.44}$ & $\overline{100.11}$ & $\overline{98.14}$ \\
\hline \multicolumn{9}{|c|}{ Trace elements, in parts per million } \\
\hline 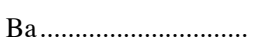 & 1,300 & 620 & 710 & 2,700 & 340 & 530 & 1,400 & 780 \\
\hline $\mathrm{Cr}$ & 70 & 10 & 10 & 60 & 32 & 35 & 20 & $<10$ \\
\hline $\mathrm{Nb}$ & 10 & 30 & 40 & $<10$ & 20 & $<10$ & 40 & 30 \\
\hline $\mathrm{Rb}$ & 160 & 160 & 110 & 290 & 150 & 90 & 70 & 140 \\
\hline $\mathrm{Sr}$ & 70 & 90 & 110 & 160 & 80 & 50 & 260 & 180 \\
\hline 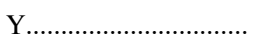 & 70 & 60 & 70 & 40 & 50 & 40 & 90 & 50 \\
\hline $\mathrm{Zr}$ & 180 & 210 & 230 & 170 & 220 & 310 & 400 & 260 \\
\hline \multicolumn{9}{|c|}{ CIPW norms, in weight percent } \\
\hline 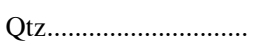 & 27.12 & 32.86 & 28.69 & 10.76 & 28.95 & 27.68 & 8.13 & 23.79 \\
\hline 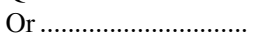 & 32.03 & 27.48 & 24.41 & 44.91 & 31.97 & 22.63 & 23.88 & 32.98 \\
\hline $\mathrm{Ab}$ & 16.92 & 30.97 & 34.02 & 12.69 & 32.66 & 44.76 & 40.11 & 32.75 \\
\hline 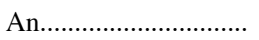 & 2.85 & 4.22 & 4.68 & 3.84 & .80 & .96 & 6.90 & 3.80 \\
\hline 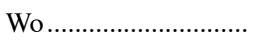 & 2.12 & - & .21 & 2.99 & .86 & - & - & .22 \\
\hline $\mathrm{Di}$ & 8.06 & 1.16 & 3.22 & 16.69 & 1.61 & .71 & 9.22 & 1.77 \\
\hline 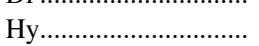 & - & .15 & - & - & - & .64 & .39 & - \\
\hline Mt........................................ & 7.60 & 2.16 & 2.53 & 3.99 & 1.25 & .08 & 6.93 & 1.31 \\
\hline 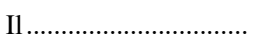 & 1.25 & .53 & 1.01 & 1.18 & .51 & .63 & 3.13 & .51 \\
\hline 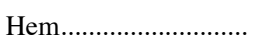 & .51 & - & .61 & - & .79 & 1.72 & - & .59 \\
\hline Ар. & .32 & .14 & .23 & .39 & .12 & .09 & 1.11 & .21 \\
\hline
\end{tabular}




\section{Sample Descriptions and Collection Localities-Table 8}

238-Foliated epidote-clinopyroxene-quartz-feldspar gneiss. Crest of small ridge, 1,250 ft northwest of intersection of Naughright and Mission Roads; Hackettstown 7.5-min quadrangle.

95-Hornblende-clinopyroxene-quartz-feldspar gneiss. Southwest end of ridge, east of New Jersey Route 206, 0.57 mi north of intersection of Central Railroad of New Jersey tracks and Hillside Avenue; Chester 7.5-min quadrangle.

S381-Titanite-clinopyroxene-quartz-feldspar gneiss. Northeast end of ridge crest, $0.30 \mathrm{mi}$ north of Interstate- $80,0.55 \mathrm{mi}$ east-northeast of north end of Lake Rogerine; Stanhope 7.5-min quadrangle.

243-Titanite-epidote-clinopyroxene-quartz-feldspar gneiss. Along ridge crest, west of Clinton Road, $800 \mathrm{ft}$ northwest of southwest end of Bearfort Waters; Wawayanda 7.5-min quadrangle.
WA200 - Titanite-clinopyroxene-quartz-feldspar gneiss. South side of Double Pond Road, 1,600 ft southeast of northeast end of Wawayanda Lake; Wawayanda 7.5-min quadrangle.

426-Titanite-clinopyroxene-quartz-feldspar gneiss. Along Burnt Meadow Brook, 0.65 mi east of intersection with Burnt Meadow Road; Wanaque 7.5-min quadrangle.

299-Medium-coarse-grained, quartz-clinopyroxene-feldspar gneiss. Interlayered with hornblende-plagioclase amphibolite. Musconetcong Mountain, $200 \mathrm{ft}$ west of Hackett Road, $0.31 \mathrm{mi}$ south of powerline; High Bridge 7.5-min quadrangle.

692-Titanite-clinopyroxene-quartz-feldspar gneiss. Interlayered with clinopyroxene-hornblende-plagioclase amphibolite. North side of draw between ridge crests, Allamuchy State Park, 0.50 mi south of Strawberry Point, Cranberry Lake; Stanhope 7.5-min quadrangle. 
Table 9. Major-oxide and trace-element concentrations and CIPW norms of diopsidite and transitional rock, New Jersey Highlands.

[GL-N is a rock type transitional between diopsidite and quartz-poor pyroxene gneiss (type A). Analyses by X-ray fluorescence spectrometry except that $\mathrm{FeO}$ contents were determined by potentiometric titration (Jackson and others, 1987). Analyses by XRAL Activation Services, Ann Arbor, Mich., for all samples but one; analysis of sample GL-N by U.S. Geological Survey, Reston, Va. NA, not analyzed. Sample localities are described following this table]

\begin{tabular}{|c|c|c|c|}
\hline & \multicolumn{2}{|c|}{ Diopsidite } & \multirow{2}{*}{$\frac{\text { Transitional rock }}{\text { GL-N }}$} \\
\hline & $647 \mathrm{P}$ & 265 & \\
\hline \multicolumn{4}{|c|}{ Major oxides and loss on ignition (LOI), in weight percent } \\
\hline $\mathrm{SiO}_{2} \ldots \ldots \ldots \ldots \ldots \ldots \ldots \ldots \ldots$ & 49.20 & 49.60 & 54.80 \\
\hline $\mathrm{TiO}_{2} \ldots \ldots \ldots \ldots \ldots \ldots \ldots \ldots \ldots$ & .39 & .46 & .15 \\
\hline $\mathrm{Al}_{2} \mathrm{O}_{3} \ldots \ldots \ldots \ldots \ldots \ldots \ldots \ldots$ & 9.82 & 4.82 & 6.70 \\
\hline $\mathrm{Fe}_{2} \mathrm{O}_{3} \ldots \ldots \ldots \ldots \ldots \ldots \ldots \ldots$ & 2.18 & 2.84 & .70 \\
\hline $\mathrm{FeO}$ & 3.50 & 3.50 & 3.10 \\
\hline $\mathrm{MgO}$ & 9.73 & 13.10 & 12.30 \\
\hline 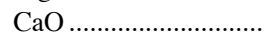 & 20.20 & 23.60 & 18.30 \\
\hline 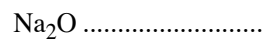 & 1.24 & .43 & 1.70 \\
\hline 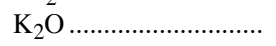 & .98 & .16 & .88 \\
\hline $\mathrm{P}_{2} \mathrm{O}_{5} \ldots \ldots \ldots \ldots \ldots$ & .32 & .01 & .02 \\
\hline $\mathrm{MnO}$ & .15 & .19 & .12 \\
\hline LOI & 1.90 & 1.23 & .83 \\
\hline Total ......................... & 99.61 & 99.94 & 99.60 \\
\hline \multicolumn{4}{|c|}{ Trace elements, in parts per million } \\
\hline $\mathrm{Ba}$ & 140 & $<10$ & NA \\
\hline $\mathrm{Cr}$ & $<10$ & $<10$ & NA \\
\hline $\mathrm{Nb}$ & 20 & $<10$ & NA \\
\hline $\mathrm{Rb}$ & 50 & 10 & NA \\
\hline $\mathrm{Sr}$ & 140 & 50 & NA \\
\hline $\mathrm{Y}$ & 20 & 30 & NA \\
\hline 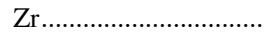 & 180 & 90 & NA \\
\hline \multicolumn{4}{|c|}{ CIPW norms, in weight percent } \\
\hline 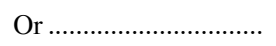 & 5.79 & - & 5.20 \\
\hline $\mathrm{Ab}$ & 3.16 & - & 14.39 \\
\hline An & 18.34 & 10.75 & 8.05 \\
\hline $\mathrm{Lc}$ & - & .74 & - \\
\hline $\mathrm{Ne}$ & 3.97 & 1.97 & - \\
\hline 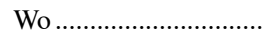 & 1.53 & 1.71 & - \\
\hline 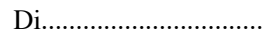 & 60.28 & 77.28 & 65.36 \\
\hline Ну & - & - & 3.39 \\
\hline $\mathrm{Ol}$ & - & - & 1.05 \\
\hline Cs & - & 1.24 & - \\
\hline Mt ................................. & 3.16 & 4.12 & 1.01 \\
\hline Il & .74 & .87 & .28 \\
\hline Аp & .74 & .02 & .05 \\
\hline
\end{tabular}




\section{Sample Descriptions and Collection Localities - Table 9}

647P-Medium-grained, poorly foliated plagioclase-clinopyroxene rock. Approximately $500 \mathrm{ft}$ northwest of sample 692; Stanhope 7.5-min quadrangle.

265-Medium-grained clinopyroxene rock interlayered with quartz-poor titanite-clinopyroxene-plagioclase gneiss and clinopyroxene-hornblende-plagioclase amphibolite. Southeast side of Allamuchy Mountain, $900 \mathrm{ft}$ west of New Jersey Route
604, 0.55 mi south-southwest of southeast end of Deer Park Pond; Tranquility 7.5-min quadrangle.

GL-N-Titanite-plagioclase-clinopyroxene rock. Interlayered with quartz-poor titanite-clinopyroxene-plagioclase gneiss (sample 242, tables 10, 11). Along west side of Lamington River, north of Pottersville, $400 \mathrm{ft}$ north of gaging station; Gladstone 7.5-min quadrangle. 
Table 10. Major-oxide concentrations in clinopyroxenes and plagioclase in sample 242 of pyroxene gneiss (Yp) from the New Jersey Highlands.

[Major-oxide concentrations in weight percent were determined by microprobe analysis by John Puffer on a JEOL Superprobe at Rutgers University. The sample locality is described below. Other data for sample 242 are given in table 11]

\begin{tabular}{|c|c|c|c|}
\hline \multirow[b]{2}{*}{$\mathrm{SiO}_{2} \ldots \ldots \ldots \ldots \ldots \ldots$} & \multicolumn{2}{|c|}{ Clinopyroxene } & \multirow{2}{*}{$\begin{array}{c}\text { Plagioclase } \\
62.91\end{array}$} \\
\hline & 51.33 & 52.05 & \\
\hline $\mathrm{TiO}_{2}$ & .20 & .15 & .00 \\
\hline $\mathrm{Al}_{2} \mathrm{O}_{3} \ldots \ldots \ldots$ & 1.62 & 1.72 & 24.05 \\
\hline $\mathrm{FeO}^{*}$ & 12.66 & 12.61 & .14 \\
\hline $\mathrm{MgO}$ & 12.01 & 11.84 & .00 \\
\hline $\mathrm{CaO}$ & 20.28 & 19.92 & 4.46 \\
\hline $\mathrm{Na}_{2} \mathrm{O}$ & .72 & .76 & 8.73 \\
\hline $\mathrm{K}_{2} \mathrm{O}$ & .00 & .00 & .32 \\
\hline Total ........................ & 98.82 & 99.05 & 100.61 \\
\hline
\end{tabular}

*All Fe reported as $\mathrm{FeO}$.

\section{Sample Description and Collection Locality - Table 10}

242-Quartz-poor titanite-clinopyroxene-plagioclase gneiss. Along west side of Lamington River, north of Pottersville, $400 \mathrm{ft}$ north of gaging station; Gladstone 7.5-min quadrangle. 
Table 11. Major-oxide and trace-element concentrations and CIPW norms of pyroxene gneiss (Yp), New Jersey Highlands.

[Analyses by X-ray fluorescence spectrometry except that $\mathrm{FeO}$ contents were determined by potentiometric titration (Jackson and others, 1987). Analyses by XRAL Activation Services, Ann Arbor, Mich. Sample localities are described following this table. Major-oxide ratios for the three geochemical types of pyroxene gneiss are given in table 12]

\begin{tabular}{|c|c|c|c|c|c|c|c|c|c|}
\hline & \multicolumn{3}{|c|}{ Type A } & \multicolumn{4}{|c|}{ Type $\mathrm{B}_{1}$} & \multicolumn{2}{|c|}{ Type $\mathrm{B}_{2}$} \\
\hline & M284 & 242 & 260 & 63 & 121 & 384 & 259 & 1045 & 58 \\
\hline \multicolumn{10}{|c|}{ Major oxides and loss on ignition (LOI), in weight percent } \\
\hline $\mathrm{SiO}_{2} \ldots \ldots \ldots \ldots \ldots \ldots \ldots \ldots \ldots$ & 52.80 & 56.60 & 59.20 & 65.40 & 67.50 & 67.60 & 68.20 & 67.90 & 75.80 \\
\hline $\mathrm{TiO}_{2} \ldots \ldots \ldots \ldots \ldots \ldots \ldots \ldots \ldots$ & .87 & .99 & .44 & .65 & .73 & .64 & .51 & .16 & .57 \\
\hline $\mathrm{Al}_{2} \mathrm{O}_{3} \ldots \ldots \ldots \ldots \ldots \ldots \ldots \ldots$ & 11.80 & 10.80 & 11.70 & 14.80 & 14.00 & 14.70 & 13.10 & 16.80 & 10.30 \\
\hline $\mathrm{Fe}_{2} \mathrm{O}_{3} \ldots \ldots$ & 2.30 & 3.44 & 3.36 & 2.13 & 2.58 & .96 & 0.93 & .45 & 1.17 \\
\hline $\mathrm{FeO}$ & 7.50 & 5.00 & 3.90 & 2.20 & 1.30 & 1.90 & 2.60 & .70 & 1.20 \\
\hline $\mathrm{MgO}$ & 3.61 & 5.09 & 3.45 & 1.42 & 1.56 & 1.40 & 1.98 & .74 & 1.44 \\
\hline $\mathrm{CaO}$ & 18.30 & 10.80 & 9.05 & 5.06 & 3.87 & 4.83 & 5.36 & 3.10 & 2.54 \\
\hline $\mathrm{Na}_{2} \mathrm{O}$ & 1.90 & 5.39 & 6.63 & 6.42 & 6.20 & 6.92 & 5.05 & 5.00 & 2.34 \\
\hline $\mathrm{K}_{2} \mathrm{O}$ & .79 & .52 & .70 & .90 & .78 & .31 & 1.53 & 3.97 & 2.64 \\
\hline $\mathrm{P}_{2} \mathrm{O}_{5} \ldots \ldots$ & .14 & .63 & .64 & .16 & .16 & .19 & .02 & .07 & .14 \\
\hline $\mathrm{MnO}$ & .19 & .11 & .06 & .12 & .06 & .15 & .05 & .03 & .04 \\
\hline LOI & .23 & .47 & .62 & .85 & .62 & .62 & .77 & .16 & 1.54 \\
\hline Total ............................ & 100.43 & 99.84 & 99.75 & 100.11 & 99.36 & 100.22 & 100.10 & 99.08 & 99.72 \\
\hline \multicolumn{10}{|c|}{ Trace elements, in parts per million } \\
\hline $\mathrm{Ba}$ & 40 & 130 & 40 & 130 & 290 & 150 & 220 & 670 & 380 \\
\hline $\mathrm{Cr}$ & 50 & 100 & 40 & $<10$ & 40 & 110 & 40 & 20 & 45 \\
\hline $\mathrm{Nb}$ & 20 & 30 & 30 & 20 & 20 & 20 & 10 & 20 & 30 \\
\hline $\mathrm{Rb}$ & 30 & 20 & 20 & 20 & 30 & 20 & 50 & 100 & 100 \\
\hline $\mathrm{Sr}$ & 380 & 70 & 70 & 260 & 180 & 230 & 180 & 170 & 180 \\
\hline $\mathrm{Y}$ & $<10$ & 80 & 80 & 90 & 40 & 90 & 50 & $<10$ & 160 \\
\hline $\mathrm{Zr} \ldots \ldots \ldots \ldots \ldots \ldots \ldots \ldots \ldots \ldots \ldots \ldots \ldots \ldots \ldots \ldots \ldots$ & 100 & 220 & 110 & 230 & 240 & 250 & 90 & 10 & 240 \\
\hline \multicolumn{10}{|c|}{ CIPW norms, in weight percent } \\
\hline Qtz & 4.41 & 1.94 & 2.28 & 14.72 & 20.46 & 16.54 & 20.97 & 16.45 & 45.13 \\
\hline 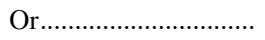 & 4.67 & 3.07 & 4.14 & 5.32 & 4.61 & 1.83 & 9.04 & 23.46 & 15.60 \\
\hline $\mathrm{Ab}$ & 16.08 & 45.61 & 56.10 & 54.32 & 52.46 & 58.56 & 42.73 & 42.31 & 19.80 \\
\hline An & 21.34 & 3.74 & .10 & 8.91 & 8.07 & 8.13 & 8.56 & 11.67 & 9.80 \\
\hline 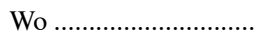 & 8.72 & .10 & 3.70 & .97 & - & .37 & - & - & - \\
\hline 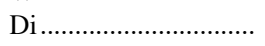 & 39.68 & 36.57 & 25.62 & 10.32 & 7.85 & 11.13 & 14.61 & 2.61 & 1.48 \\
\hline 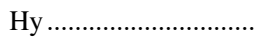 & - & - & - & - & .24 & - & 1.05 & 1.29 & 3.26 \\
\hline Mt & 3.33 & 4.99 & 4.87 & 3.09 & 2.27 & 1.39 & 1.35 & .65 & 1.70 \\
\hline 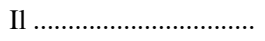 & 1.65 & 1.88 & .84 & 1.23 & 1.39 & 1.22 & .97 & .30 & 1.08 \\
\hline 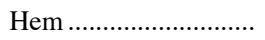 & - & - & - & - & 1.01 & - & - & - & - \\
\hline Ap & .32 & 1.46 & 1.48 & .37 & .37 & .44 & .05 & .16 & .32 \\
\hline
\end{tabular}




\section{Sample Descriptions and Collection Localities-Table 11}

M284-Medium-grained, well-layered graphite-titanite-clinopyroxene-plagioclase gneiss. South side of Sussex Turnpike, $1,250 \mathrm{ft}$ southeast of intersection with Morris Turnpike; Mendham 7.5-min quadrangle.

242-Quartz-poor titanite-clinopyroxene-plagioclase gneiss. Along west side of Lamington River, north of Pottersville, 400 $\mathrm{ft}$ north of gaging station; Gladstone 7.5-min quadrangle.

260 - Titanite-clinopyroxene-plagioclase gneiss. East side of Canistear Road, 0.35 mi south of south end of Highland Lake; Wawayanda 7.5-min quadrangle.

63-Titanite-clinopyroxene-quartz-plagioclase gneiss. Crest of Jenny Jump Mountain, 0.28 mi northwest of south end of unnamed pond and Mountain Lake Brook; Blairstown 7.5-min quadrangle.

121 - Titanite-clinopyroxene-quartz-plagioclase gneiss. Ridge west of Stony Brook, $250 \mathrm{ft}$ northeast of end of Crest Drive; Hackettstown 7.5-min quadrangle.
384-Titanite-clinopyroxene-quartz-plagioclase gneiss. Interlayered with thin hornblende-plagioclase amphibolite. West side of Jenny Jump Mountain, $0.43 \mathrm{mi}$ south-southwest of intersection of Beaver Brook and New Jersey Route 519; Washington 7.5-min quadrangle.

259-Titanite-clinopyroxene-quartz-plagioclase gneiss. West end of ridge, north of South Branch Raritan River, 0.53 mi southwest of intersection of New Jersey Route 513 and Hoffmans Crossing Road; Califon 7.5-min quadrangle.

1045-Titanite-hornblende-clinopyroxene-quartz-feldspar gneiss. North side of Sussex Mills Road, 0.95 mi northwest of intersection with Fox Hollow Road; Newton East 7.5-min quadrangle.

58-Epidote-titanite-clinopyroxene-feldspar-quartz gneiss. East side of Long House Drive, $0.57 \mathrm{mi}$ north of intersection with Lake Shore Drive; Greenwood Lake 7.5-min quadrangle. 
Table 12. Major-oxide ratios for the three geochemical types of pyroxene gneiss (Yp), New Jersey Highlands.

[Major-oxide and trace-element concentrations and CIPW norms of all samples but one are in table 11; data for sample GL-N are in table 9]

\begin{tabular}{lllll}
\hline Sample & $\mathrm{Fe}_{2} \mathrm{O}_{3}{ }^{*}+\mathrm{MgO}$ & $\mathrm{Al}_{2} \mathrm{O}_{3} / \mathrm{SiO}_{2}$ & $\mathrm{Al}_{2} \mathrm{O}_{3} /\left(\mathrm{CaO}+\mathrm{Na}_{2} \mathrm{O}\right)$ & $\mathrm{K}_{2} \mathrm{O} / \mathrm{Na}_{2} \mathrm{O}$ \\
\hline
\end{tabular}

Transitional rock

[GL-N is a rock type transitional between diopsidite and $\mathrm{SiO}_{2}$-poor pyroxene gneiss]

\begin{tabular}{|c|c|c|c|c|}
\hline GL-N ………............ & 16.10 & 0.12 & 0.34 & 0.52 \\
\hline \multicolumn{5}{|c|}{$\mathrm{SiO}_{2}$-poor pyroxene gneiss (type $\mathrm{A}$ ) } \\
\hline M284 …........................... & 13.41 & 0.22 & 0.58 & 0.42 \\
\hline 242 & 13.53 & .19 & .67 & .10 \\
\hline 260 & 10.71 & .20 & .75 & .11 \\
\hline \multicolumn{5}{|c|}{$\mathrm{SiO}_{2}$-rich pyroxene gneiss having intermediate $\mathrm{CaO}$ contents (type $\mathrm{B}_{1}$ ) } \\
\hline 63 & 5.75 & 0.23 & 1.29 & 0.14 \\
\hline 121 & 5.44 & .21 & 1.39 & .13 \\
\hline 384 & 4.26 & .22 & 1.25 & .04 \\
\hline 259 & 5.51 & .19 & 1.26 & .30 \\
\hline \multicolumn{5}{|c|}{$\mathrm{SiO}_{2}$-rich pyroxene gneiss having low $\mathrm{CaO}$ contents (type $\mathrm{B}_{2}$ ) } \\
\hline 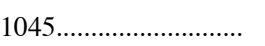 & 1.89 & 0.25 & 2.07 & 0.79 \\
\hline 58 & 3.81 & .14 & 2.11 & 1.13 \\
\hline
\end{tabular}

*All Fe reported as $\mathrm{Fe}_{2} \mathrm{O}_{3}$. 
Table 13. Major-oxide and trace-element concentrations and CIPW norms of pyroxene-epidote gneiss (Ype) and quartz-epidote gneiss (Ye), New Jersey Highlands.

[Analyses by X-ray fluorescence spectrometry except that FeO contents were determined by potentiometric titration (Jackson and others, 1987). Analyses by XRAL Activation Services, Ann Arbor, Mich. Sample localities are described following this table]

\begin{tabular}{|c|c|c|c|c|c|c|c|c|}
\hline & \multicolumn{7}{|c|}{ Pyroxene-epidote gneiss (Ype) } & \multirow{2}{*}{$\begin{array}{c}\text { Quartz-epidote } \\
\text { gneiss (Ye) } \\
417 \mathrm{E}\end{array}$} \\
\hline & F85 & 369 & $\mathrm{H} 380$ & 417 & B42 & $\mathrm{T} 37$ & 224 & \\
\hline \multicolumn{9}{|c|}{ Major oxides and loss on ignition (LOI), in weight percent } \\
\hline $\mathrm{SiO}_{2} \ldots \ldots \ldots \ldots \ldots \ldots \ldots$ & 77.90 & 73.40 & 73.70 & 70.50 & 71.80 & 56.50 & 62.10 & 72.40 \\
\hline $\mathrm{TiO}_{2} \ldots \ldots \ldots \ldots \ldots \ldots \ldots$ & .46 & .62 & .69 & .55 & .72 & 1.02 & .96 & .71 \\
\hline $\mathrm{Al}_{2} \mathrm{O}_{3} \ldots \ldots \ldots \ldots \ldots \ldots$ & 8.48 & 10.30 & 9.69 & 11.00 & 10.30 & 13.20 & 11.40 & 10.90 \\
\hline $\mathrm{Fe}_{2} \mathrm{O}_{3} \ldots \ldots \ldots \ldots \ldots \ldots$ & 1.15 & 4.86 & 5.65 & 4.32 & 3.31 & 6.04 & 5.78 & 4.15 \\
\hline $\mathrm{FeO}$ & .40 & .60 & .30 & .40 & 1.70 & 3.10 & 1.90 & .10 \\
\hline $\mathrm{MgO}$ & .87 & .76 & 1.16 & 1.28 & 1.23 & 3.10 & 1.80 & .71 \\
\hline $\mathrm{CaO}$ & 3.76 & 1.99 & 3.25 & 5.84 & 6.81 & 8.21 & 8.93 & 7.54 \\
\hline $\mathrm{Na}_{2} \mathrm{O}$ & .63 & 1.48 & .93 & .38 & 1.68 & 2.33 & 1.21 & 2.39 \\
\hline $\mathrm{K}_{2} \mathrm{O}$ & 3.65 & 4.88 & 3.41 & 2.44 & 1.38 & 4.31 & 1.53 & .07 \\
\hline $\mathrm{P}_{2} \mathrm{O}_{5}$ & .08 & .12 & .12 & .12 & .15 & .25 & .26 & .17 \\
\hline $\mathrm{MnO}$ & .04 & .06 & .14 & .14 & .07 & .18 & .17 & .10 \\
\hline LOI .............................. & .62 & .70 & .75 & 1.55 & .93 & .93 & 2.47 & .35 \\
\hline Total ……............. & 98.04 & 99.77 & 99.79 & 98.52 & 100.08 & 99.17 & 98.51 & 99.59 \\
\hline \multicolumn{9}{|c|}{ Trace elements, in parts per million } \\
\hline $\mathrm{Ba}$ & 560 & 590 & 610 & 100 & 330 & 770 & 410 & $<50$ \\
\hline $\mathrm{Cr}$ & 30 & 270 & 150 & 20 & 80 & 70 & 60 & 60 \\
\hline $\mathrm{Nb}$ & 30 & 40 & 50 & 40 & 40 & 10 & 10 & 30 \\
\hline $\mathrm{Rb}$ & 130 & 130 & 100 & 50 & 50 & 130 & 70 & $<10$ \\
\hline $\mathrm{Sr}$ & 150 & 110 & 130 & 80 & 200 & 310 & 80 & 280 \\
\hline $\mathrm{Y}$ & 40 & 90 & 80 & 100 & 40 & 30 & 30 & 20 \\
\hline $\mathrm{Zr}$ & 150 & 610 & 860 & 610 & 510 & 200 & 240 & 400 \\
\hline \multicolumn{9}{|c|}{ CIPW norms, in weight percent } \\
\hline Qtz $\ldots \ldots \ldots \ldots \ldots \ldots \ldots \ldots$ & 52.99 & 41.50 & 47.56 & 46.40 & 44.27 & 10.62 & 32.75 & 45.27 \\
\hline Or ........................... & 21.57 & 28.84 & 20.15 & 14.42 & 8.16 & 25.47 & 9.04 & .41 \\
\hline $\mathrm{Ab}$ & 5.33 & 12.52 & 7.87 & 3.22 & 14.22 & 19.72 & 10.24 & 20.22 \\
\hline 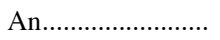 & 9.53 & 7.05 & 12.20 & 21.10 & 16.49 & 12.83 & 21.16 & 18.81 \\
\hline 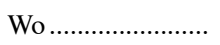 & 1.08 & - & - & - & 3.27 & 2.04 & 3.77 & 4.55 \\
\hline Di............................. & 4.67 & 1.59 & 1.91 & 5.52 & 6.61 & 16.65 & 9.67 & 3.81 \\
\hline 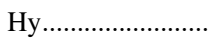 & - & 1.16 & 2.00 & .63 & - & - & - & - \\
\hline Mt ......................... & .09 & .33 & - & .15 & 3.62 & 7.62 & 3.90 & - \\
\hline Il ...... & .87 & 1.18 & .93 & 1.04 & 1.37 & 1.94 & 1.82 & .43 \\
\hline Hem............................... & 1.09 & 4.63 & 5.65 & 4.22 & .81 & .78 & 3.09 & 4.15 \\
\hline Ti .......................... & - & - & .49 & - & - & - & - & 1.19 \\
\hline Ap & .19 & .28 & .28 & .28 & .35 & .58 & .60 & .39 \\
\hline
\end{tabular}




\section{Sample Descriptions and Collection Localities-Table 13}

F85-Medium-grained, layered titanite-epidote-clinopyroxenefeldspar-quartz gneiss. Immediately north of dam, north end of Tamarack Lake; Franklin 7.5-min quadrangle.

369-Biotite-clinopyroxene-epidote-quartz-feldspar gneiss. Hamburg Mountain, along unnamed stream, 0.37 mi south-southeast of intersection of New Jersey Routes 517 and 94; Hamburg 7.5-min quadrangle.

HM380-Biotite-epidote-clinopyroxene-feldspar-quartz gneiss. Hamburg Mountain, west of powerline, 0.29 mi southeast of intersection of New Jersey Route 517 and Old Rudetown Road; Hamburg 7.5-min quadrangle.

417-Clinopyroxene-epidote-quartz-feldspar gneiss. Interlayered with epidote-plagioclase-quartz gneiss (sample 417E, table 13). Hamburg Mountain, east side of unimproved road,
0.32 mi east of intersection of New Jersey Routes 517 and 94; Hamburg 7.5-min quadrangle.

B42-Titanite-clinopyroxene-epidote-feldspar-quartz gneiss. Southeast side of intersection of Shades of Death Road and New Jersey Route 611, Marble Hill; Blairstown 7.5-min quadrangle.

T37-Titanite-hornblende-clinopyroxene-epidote-feldspar gneiss. Eastbound Interstate-80, 0.58 mi east of intersection with New Jersey Route 613; Tranquility 7.5-min quadrangle.

224-Titanite-clinopyroxene-quartz-epidote-feldspar gneiss. South side of High Rock Mountain, 0.40 mi northeast of intersection of Beechwood and Free Union Roads; Washington 7.5-min quadrangle.

417E-Well-layered epidote-plagioclase-quartz gneiss. Same location as sample 417; Hamburg 7.5-min quadrangle. 
Table 14. Major-oxide and trace-element concentrations and CIPW norms of Byram Intrusive Suite rocks, New Jersey Highlands.

[Analyses by X-ray fluorescence spectrometry except that $\mathrm{FeO}$ contents were determined by potentiometric titration (Jackson and others, 1987). Analyses by XRAL Activation Services, Ann Arbor, Mich., for all samples but two; analyses of samples 999 and D1 by U.S. Geological Survey, Reston, Va. NA, not analyzed. Sample localities are described following this table]

\begin{tabular}{|c|c|c|c|c|c|c|c|}
\hline & \multicolumn{7}{|c|}{ Hornblende granite (Ybh) } \\
\hline & 999 & M65 & M291 & C66 & 613 & WQ200 & B8 \\
\hline \multicolumn{8}{|c|}{ Major oxides and loss on ignition (LOI), in weight percent } \\
\hline $\mathrm{SiO}_{2} \ldots \ldots \ldots \ldots \ldots \ldots \ldots \ldots \ldots$ & 77.50 & 69.10 & 70.30 & 71.60 & 74.80 & 70.70 & 73.60 \\
\hline $\mathrm{TiO}_{2} \ldots \ldots \ldots \ldots \ldots \ldots \ldots \ldots$ & .46 & .49 & .43 & .24 & .23 & .55 & .17 \\
\hline $\mathrm{Al}_{2} \mathrm{O}_{3} \ldots \ldots \ldots \ldots \ldots \ldots \ldots$ & 10.00 & 13.00 & 13.70 & 12.60 & 13.00 & 13.50 & 14.00 \\
\hline $\mathrm{Fe}_{2} \mathrm{O}_{3} \ldots \ldots \ldots \ldots \ldots \ldots \ldots \ldots \ldots \ldots$ & 1.00 & 1.95 & 1.70 & 1.62 & .40 & 2.09 & .12 \\
\hline $\mathrm{FeO}$ & 1.80 & 3.60 & 2.20 & 2.10 & 1.10 & 2.70 & 1.11 \\
\hline $\mathrm{MgO}$ & 1.00 & .27 & .30 & .15 & .25 & .39 & .16 \\
\hline $\mathrm{CaO}$ & 1.50 & 1.86 & 1.45 & 1.56 & 1.34 & 1.57 & .81 \\
\hline $\mathrm{Na}_{2} \mathrm{O}$ & .82 & 3.12 & 2.79 & 3.03 & 2.97 & 3.44 & 3.12 \\
\hline $\mathrm{K}_{2} \mathrm{O}$ & 4.50 & 5.15 & 5.75 & 4.91 & 5.52 & 5.06 & 5.69 \\
\hline $\mathrm{P}_{2} \mathrm{O}_{5}$ & .10 & .09 & .09 & .02 & .04 & .10 & .04 \\
\hline $\mathrm{MnO}$ & .04 & .08 & .06 & .04 & .03 & .06 & .02 \\
\hline LOI............................... & 1.34 & .47 & .77 & .77 & .23 & .08 & .85 \\
\hline Total ........................ & 100.06 & 99.18 & 99.54 & 98.64 & 99.91 & 100.24 & 99.69 \\
\hline \multicolumn{8}{|c|}{ Trace elements, in parts per million } \\
\hline $\mathrm{Ba}$ & NA & 1,300 & 1,200 & 470 & 800 & 810 & 680 \\
\hline $\mathrm{Cr}$ & NA & $<10$ & 10 & 10 & 10 & 10 & 30 \\
\hline $\mathrm{Nb}$ & NA & 20 & 20 & 20 & $<10$ & 50 & $<10$ \\
\hline $\mathrm{Rb}$ & NA & 170 & 170 & 160 & 190 & 140 & 130 \\
\hline $\mathrm{Sr}$ & NA & 100 & 140 & 70 & 100 & 80 & 120 \\
\hline $\mathrm{Y}$ & NA & 100 & 120 & 300 & 50 & 90 & 50 \\
\hline $\mathrm{Zr}$ & NA & 750 & 480 & 390 & 270 & 880 & 740 \\
\hline \multicolumn{8}{|c|}{ CIPW norms, in weight percent } \\
\hline 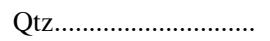 & 50.38 & 25.64 & 27.84 & 30.96 & 32.76 & 26.70 & 31.04 \\
\hline 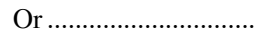 & 26.59 & 30.44 & 33.98 & 29.02 & 32.62 & 29.90 & 33.63 \\
\hline $\mathrm{Ab}$ & 6.94 & 26.40 & 23.61 & 25.64 & 25.13 & 29.11 & 26.40 \\
\hline 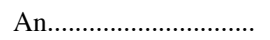 & 6.54 & 6.26 & 6.61 & 6.28 & 5.84 & 6.45 & 3.76 \\
\hline 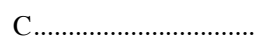 & 1.39 & - & .47 & - & - & - & 1.33 \\
\hline Di ................................. & - & 2.08 & - & 1.16 & .47 & .58 & - \\
\hline 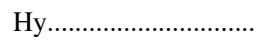 & 4.28 & 3.93 & 2.78 & 1.97 & 1.75 & 3.11 & 2.09 \\
\hline Mt........................... & 1.45 & 2.83 & 2.46 & 2.35 & .58 & 3.03 & .17 \\
\hline Il .............................. & .87 & .93 & .82 & .46 & .44 & 1.04 & .32 \\
\hline 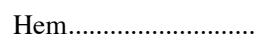 & - & - & - & - & - & - & - \\
\hline Ар & .23 & .21 & .21 & .05 & .09 & .23 & .09 \\
\hline Сс & .09 & - & - & - & - & - & - \\
\hline
\end{tabular}


Table 14. Major-oxide and trace-element concentrations and CIPW norms of Byram Intrusive Suite rocks, New Jersey Highlands-Continued.

\begin{tabular}{|c|c|c|c|c|c|c|c|c|}
\hline & \multicolumn{8}{|c|}{ Hornblende granite $(\mathrm{Ybh})$-Continued } \\
\hline & 9 & 148 & 359 & 263 & $\mathrm{C} 10$ & 193 & H393 & 99 \\
\hline \multicolumn{9}{|c|}{ Major oxides and loss on ignition (LOI), in weight percent } \\
\hline $\mathrm{SiO}_{2} \ldots \ldots \ldots \ldots \ldots \ldots \ldots \ldots \ldots$ & 73.10 & 69.30 & 68.20 & 70.90 & 72.90 & 68.10 & 72.00 & 73.70 \\
\hline $\mathrm{TiO}_{2} \ldots \ldots \ldots \ldots \ldots \ldots \ldots \ldots$ & .12 & .51 & .58 & .51 & .35 & .55 & .29 & .19 \\
\hline $\mathrm{Al}_{2} \mathrm{O}_{3} \ldots \ldots \ldots \ldots \ldots \ldots \ldots$ & 13.70 & 13.50 & 13.80 & 12.30 & 12.50 & 14.00 & 12.00 & 13.50 \\
\hline $\mathrm{Fe}_{2} \mathrm{O}_{3} \ldots \ldots \ldots \ldots \ldots$ & .10 & 2.10 & 1.88 & 2.40 & 1.70 & 2.07 & 1.56 & 1.35 \\
\hline $\mathrm{FeO}$ & .92 & 2.70 & 3.90 & 3.50 & 2.00 & 3.30 & 2.60 & .60 \\
\hline $\mathrm{MgO}$ & .22 & .41 & .41 & .28 & .30 & .47 & .24 & .12 \\
\hline $\mathrm{CaO}$ & 1.12 & 1.92 & 2.10 & 1.93 & 1.32 & 2.35 & 1.43 & .73 \\
\hline $\mathrm{Na}_{2} \mathrm{O}$ & 3.68 & 3.25 & 3.18 & 3.31 & 2.76 & 3.09 & 3.50 & 4.54 \\
\hline $\mathrm{K}_{2} \mathrm{O}$ & 5.33 & 5.50 & 5.23 & 4.38 & 5.79 & 5.63 & 5.13 & 4.42 \\
\hline $\mathrm{P}_{2} \mathrm{O}_{5}$ & .03 & .12 & .13 & .11 & .08 & .16 & .04 & .03 \\
\hline $\mathrm{MnO}$ & .03 & .08 & .09 & .07 & .05 & .08 & .11 & .02 \\
\hline LOI & 1.00 & .47 & .08 & .20 & .01 & .20 & .25 & .47 \\
\hline Total .......................... & 99.35 & 99.86 & 99.58 & 99.89 & 99.76 & 100.00 & 99.15 & 99.67 \\
\hline \multicolumn{9}{|c|}{ Trace elements, in parts per million } \\
\hline $\mathrm{Ba}$ & 360 & 1,200 & 1,100 & 1,100 & 910 & 1,400 & 610 & 870 \\
\hline 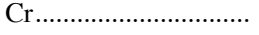 & 30 & 20 & $<10$ & NA & 50 & 10 & $<10$ & 10 \\
\hline $\mathrm{Nb}$ & $<10$ & 30 & 30 & 60 & 40 & 40 & 40 & $<10$ \\
\hline $\mathrm{Rb}$ & 170 & 170 & 140 & 130 & 150 & 140 & 130 & 80 \\
\hline $\mathrm{Sr}$ & 120 & 140 & 150 & 130 & 140 & 150 & 80 & 170 \\
\hline $\mathrm{Y}$ & 70 & 90 & 110 & 100 & 110 & 80 & 160 & $<10$ \\
\hline $\mathrm{Zr}$ & 870 & 610 & 600 & 1,300 & 450 & 620 & 810 & 170 \\
\hline \multicolumn{9}{|c|}{ CIPW norms, in weight percent } \\
\hline 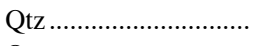 & 28.04 & 24.40 & 23.10 & 29.61 & 31.13 & 22.29 & 28.30 & 28.72 \\
\hline Or................................. & 31.50 & 32.50 & 30.91 & 25.88 & 34.22 & 33.27 & 30.32 & 26.12 \\
\hline $\mathrm{Ab}$ & 31.14 & 27.50 & 26.91 & 28.01 & 23.35 & 26.15 & 29.62 & 38.42 \\
\hline An & 5.12 & 6.01 & 7.94 & 5.77 & 4.62 & 7.70 & 1.88 & 3.40 \\
\hline С & - & - & - & - & - & - & - & - \\
\hline 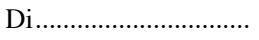 & .20 & 2.33 & 1.42 & 2.68 & 1.20 & 2.50 & 4.30 & .02 \\
\hline Ну & 1.91 & 2.36 & 5.10 & 3.03 & 1.92 & 3.48 & 1.57 & .29 \\
\hline Mt ............................... & .14 & 3.04 & 2.73 & 3.48 & 2.46 & 3.00 & 2.26 & 1.45 \\
\hline Il & .23 & .97 & 1.10 & .97 & .66 & 1.04 & .55 & .36 \\
\hline Hem & - & - & - & - & - & - & - & .35 \\
\hline Аp & .07 & .28 & .30 & .25 & .19 & .37 & .09 & .07 \\
\hline Сc & - & - & - & - & - & - & - & - \\
\hline
\end{tabular}


Table 14. Major-oxide and trace-element concentrations and CIPW norms of Byram Intrusive Suite rocks, New Jersey Highlands-Continued.

\begin{tabular}{|c|c|c|c|c|c|c|}
\hline & \multicolumn{3}{|c|}{ Hornblende granite $(\mathrm{Ybh}$ )-Continued } & \multicolumn{3}{|c|}{ Hornblende syenite (Ybs) } \\
\hline & D1 & C159 & 38 & 153 & 173 & S147 \\
\hline \multicolumn{7}{|c|}{ Major oxides and loss on ignition (LOI), in weight percent } \\
\hline $\mathrm{SiO}_{2} \ldots \ldots \ldots \ldots \ldots \ldots \ldots \ldots \ldots$ & 67.60 & 67.60 & 66.30 & 60.80 & 63.50 & 61.60 \\
\hline $\mathrm{TiO}_{2} \ldots \ldots \ldots \ldots \ldots \ldots \ldots \ldots$ & .87 & .60 & .46 & .77 & .58 & .66 \\
\hline $\mathrm{Al}_{2} \mathrm{O}_{3} \ldots \ldots \ldots \ldots \ldots \ldots \ldots \ldots$ & 13.40 & 14.40 & 16.00 & 17.30 & 14.90 & 17.10 \\
\hline $\mathrm{Fe}_{2} \mathrm{O}_{3} \ldots \ldots \ldots \ldots \ldots \ldots \ldots \ldots$ & 3.40 & 2.03 & 1.32 & 2.53 & 3.54 & 3.07 \\
\hline $\mathrm{FeO}$ & 2.70 & 2.40 & 2.70 & 3.50 & 3.40 & 3.70 \\
\hline $\mathrm{MgO}$ & .56 & .65 & 0.36 & 1.17 & 0.45 & .52 \\
\hline $\mathrm{CaO}$ & 2.00 & 2.48 & 2.38 & 2.97 & 1.96 & 2.22 \\
\hline $\mathrm{Na}_{2} \mathrm{O}$ & 3.00 & 3.53 & 5.20 & 3.92 & 4.38 & 4.50 \\
\hline $\mathrm{K}_{2} \mathrm{O}$ & 4.40 & 4.51 & 4.79 & 6.17 & 5.74 & 6.59 \\
\hline $\mathrm{P}_{2} \mathrm{O}_{5}$ & .15 & .15 & .08 & .17 & .09 & .12 \\
\hline $\mathrm{MnO}$ & .06 & .03 & .05 & .07 & .18 & .17 \\
\hline LOI & .55 & .47 & .08 & .54 & .47 & .06 \\
\hline Total............................ & 98.69 & 98.85 & 99.72 & 99.91 & 99.19 & 100.31 \\
\hline \multicolumn{7}{|c|}{ Trace elements, in parts per million } \\
\hline 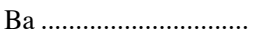 & NA & 1,500 & 1,300 & 1,800 & 530 & 1,100 \\
\hline Cr............................... & NA & 10 & 20 & 20 & 10 & $<10$ \\
\hline $\mathrm{Nb}$ & NA & 10 & 40 & 30 & 50 & 20 \\
\hline $\mathrm{Rb}$ & NA & 100 & 70 & 160 & 100 & 90 \\
\hline $\mathrm{Sr}$ & NA & 300 & 230 & 500 & 70 & 150 \\
\hline Y & NA & 70 & 60 & 60 & 150 & 60 \\
\hline $\mathrm{Zr}$ & NA & 460 & 910 & 780 & 1,400 & 1,500 \\
\hline \multicolumn{7}{|c|}{ CIPW norms, in weight percent } \\
\hline Qtz ............................ & 28.32 & 23.39 & 11.95 & 5.78 & 11.31 & 4.12 \\
\hline Or............................... & 26.00 & 26.65 & 28.31 & 36.46 & 33.92 & 38.95 \\
\hline $\mathrm{Ab} \ldots \ldots \ldots \ldots \ldots \ldots \ldots \ldots \ldots$ & 25.39 & 29.87 & 44.00 & 33.17 & 37.06 & 38.08 \\
\hline 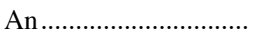 & 8.75 & 10.13 & 6.17 & 11.39 & 4.04 & 7.00 \\
\hline $\mathrm{C}$ & .49 & - & - & - & - & - \\
\hline $\mathrm{Di}$ & - & .99 & 4.40 & 1.86 & 4.34 & 2.76 \\
\hline 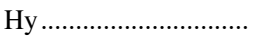 & 2.22 & 2.92 & 1.83 & 5.19 & 1.61 & 3.37 \\
\hline 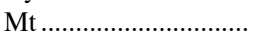 & 4.93 & 2.94 & 1.91 & 3.67 & 5.13 & 4.45 \\
\hline Il & 1.65 & 1.14 & .87 & 1.46 & 1.10 & 1.25 \\
\hline 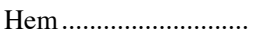 & - & - & - & - & - & - \\
\hline 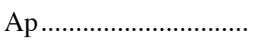 & .35 & .35 & .19 & .39 & .21 & .28 \\
\hline $\mathrm{Cc}$ & .07 & - & - & - & - & - \\
\hline
\end{tabular}


Table 14. Major-oxide and trace-element concentrations and CIPW norms of Byram Intrusive Suite rocks, New Jersey Highlands-Continued.

\begin{tabular}{|c|c|c|c|c|c|}
\hline & \multicolumn{3}{|c|}{ Hornblende syenite $(\mathrm{Ybs})$-Continued } & \multicolumn{2}{|c|}{$\begin{array}{l}\text { Microperthite } \\
\text { alaskite (Yba) }\end{array}$} \\
\hline & 70 & W291 & 313 & 6 & H10 \\
\hline \multicolumn{6}{|c|}{ Major oxides and loss on ignition (LOI), in weight percent } \\
\hline $\mathrm{SiO}_{2} \ldots \ldots \ldots \ldots \ldots \ldots \ldots \ldots \ldots$ & 58.10 & 62.00 & 61.80 & 72.80 & 71.40 \\
\hline $\mathrm{TiO}_{2} \ldots \ldots \ldots \ldots \ldots \ldots \ldots \ldots \ldots$ & .86 & .91 & .56 & .10 & .21 \\
\hline $\mathrm{Al}_{2} \mathrm{O}_{3} \ldots \ldots \ldots \ldots \ldots \ldots \ldots$ & 18.50 & 15.30 & 17.00 & 14.00 & 14.50 \\
\hline $\mathrm{Fe}_{2} \mathrm{O}_{3} \ldots \ldots \ldots \ldots$ & 2.20 & 4.23 & 3.20 & .12 & .12 \\
\hline $\mathrm{FeO}$ & 4.30 & 3.20 & 3.30 & 1.09 & 1.04 \\
\hline $\mathrm{MgO}$ & 1.01 & 1.30 & .42 & .21 & .53 \\
\hline $\mathrm{CaO}$ & 4.62 & 3.88 & 1.69 & .65 & 1.38 \\
\hline $\mathrm{Na}_{2} \mathrm{O} \ldots \ldots \ldots \ldots \ldots \ldots \ldots \ldots$ & 5.00 & 4.21 & 5.08 & 4.09 & 2.81 \\
\hline $\mathrm{K}_{2} \mathrm{O}$ & 4.33 & 3.54 & 5.90 & 5.31 & 5.84 \\
\hline $\mathrm{P}_{2} \mathrm{O}_{5}$ & .32 & .32 & .15 & .03 & .07 \\
\hline $\mathrm{MnO}$ & .12 & .10 & .09 & .03 & .02 \\
\hline 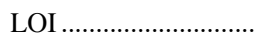 & .47 & .31 & .23 & .70 & 1.23 \\
\hline Total ......................... & 99.83 & 99.30 & 99.42 & 99.13 & 99.15 \\
\hline \multicolumn{6}{|c|}{ Trace elements, in parts per million } \\
\hline 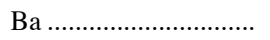 & 2,000 & 1,500 & 1,300 & 470 & 830 \\
\hline $\mathrm{Cr}$ & 12 & 10 & $<10$ & 20 & 40 \\
\hline $\mathrm{Nb}$ & 20 & 30 & 30 & $<10$ & $<10$ \\
\hline $\mathrm{Rb}$ & 60 & 100 & 110 & 140 & 190 \\
\hline $\mathrm{Sr}$ & 510 & 360 & 250 & 100 & 290 \\
\hline $\mathrm{Y}$ & 40 & 60 & 60 & $<10$ & 30 \\
\hline $\mathrm{Zr}$ & 760 & 670 & 1,200 & 380 & 380 \\
\hline \multicolumn{6}{|c|}{ CIPW norms, in weight percent } \\
\hline 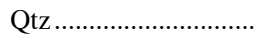 & .92 & 15.16 & 4.90 & 26.25 & 28.47 \\
\hline 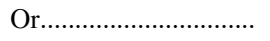 & 25.59 & 20.92 & 34.87 & 31.38 & 34.51 \\
\hline $\mathrm{Ab}$ & 42.31 & 35.62 & 42.99 & 34.61 & 23.78 \\
\hline An & 15.25 & 12.40 & 6.16 & 3.03 & 6.39 \\
\hline 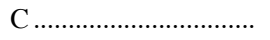 & - & - & - & .41 & 1.22 \\
\hline 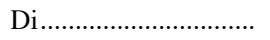 & 4.72 & 3.82 & 1.06 & - & - \\
\hline 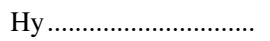 & 5.01 & 2.48 & 3.16 & 2.32 & 2.82 \\
\hline Mt & 3.19 & 6.13 & 4.64 & .17 & .17 \\
\hline 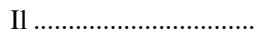 & 1.63 & 1.73 & 1.06 & .19 & .40 \\
\hline 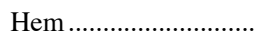 & - & - & - & - & - \\
\hline Ap & .74 & .74 & .35 & .07 & .16 \\
\hline Сc & - & - & - & - & - \\
\hline
\end{tabular}




\section{Sample Descriptions and Collection Localities-Table 14}

999-Medium- to medium-coarse-grained, foliated hornblende granite. East of Sparta, 0.53 mi east of intersection of New Jersey Routes 517 and 613; Newton East 7.5-min quadrangle.

M65-Hornblende granite. West side of Summit Road, 1,000 ft north of intersection with West Main Street; Mendham 7.5-min quadrangle.

M291 - Foliated clinopyroxene-hornblende granite. East side of steep ridge, south of powerline, $0.88 \mathrm{mi}$ west-southwest of southwest end of Shongum Lake; Mendham 7.5-min quadrangle.

C66-Hornblende granite. East side of New Jersey Route 517, $300 \mathrm{ft}$ north of intersection with Saw Mill Road, Lower Fairmount; Califon 7.5-min quadrangle.

613-Hornblende granite. Northbound New Jersey Route 23, 0.31 mi north of intersection with Macopin River; Newfoundland 7.5-min quadrangle.

WQ200-Medium-grained, gneissic hornblende granite. Approximately $500 \mathrm{ft}$ north of powerline and $900 \mathrm{ft}$ east of intersection with Ridge Road; Wanaque 7.5-min quadrangle.

B8 - Hornblende granite. North side of unnamed stream, $500 \mathrm{ft}$ north-northeast of intersection of Campbell Road and Stevens Lane; Bernardsville 7.5-min quadrangle.

9-Hornblende granite. Musconetcong Mountain, location uncertain; High Bridge 7.5-min quadrangle.

148-Hornblende granite. East side of steep ridge, north of East Shore Road, 0.25 mi north-northwest of intersection of Jennings Creek and Wanaque River; Greenwood Lake 7.5-min quadrangle.

359-Clinopyroxene-hornblende granite. Ridge crest along powerline, $0.38 \mathrm{mi}$ southwest of intersection with Shongum Road; Mendham 7.5-min quadrangle.

263-Hornblende granite. East side of steep ridge, 0.21 mi north of intersection of railroad tracks and Skyline Drive; Wanaque 7.5-min quadrangle.

C10-Hornblende granite. East side of North Branch Raritan River, 0.6 mi south of intersection of Roxciticus and Union School House Roads, Pleasant Valley; Chester 7.5-min quadrangle.

193-Hornblende granite. East side of ridge, west of Morsetown Road, 0.48 mi northwest of northwest end of Kitchell Lake; Wanaque 7.5 -min quadrangle.
H393-Clinopyroxene-hornblende granite. Hamburg Mountain, 0.64 mi south-southwest of intersection of New Jersey Route 94 and Sand Hill Road; Hamburg 7.5-min quadrangle.

99-Hornblende granite. Along North Branch Raritan River, immediately south of dam, south end of Ravine Lake; Gladstone 7.5-min quadrangle.

D1 - Locally pegmatitic hornblende quartz syenite. Northbound New Jersey Route 15, 0.23 mi southeast of intersection of Cooper Road and southbound New Jersey Route 15, Tierneys Corner; Dover 7.5-min quadrangle.

C159-Hornblende quartz syenite. West side of New Jersey Route 206, $250 \mathrm{ft}$ north of intersection with Cooper Lane; Chester 7.5-min quadrangle.

38-Hornblende quartz syenite. South side of trail, Middle Valley, 0.20 mi southeast of southwest end of MacMillan Reservoir; Ramsey 7.5-min quadrangle.

153-Foliated hornblende syenite. North side of Mountain Avenue, 0.43 mi east of intersection with New Jersey Route 511; Pompton Plains 7.5-min quadrangle.

173-Hornblende syenite. South side of unnamed stream, 1,250 ft southeast of intersection with Musconetcong River, $0.76 \mathrm{mi}$ southwest of intersection of New Jersey Route 517 and Kings Highway; Hackettstown 7.5-min quadrangle.

S147-Hornblende syenite. West side of New Jersey Route 605 in bend, 0.46 mi south of intersection with Amity Road; Stanhope 7.5-min quadrangle.

70-Gneissic hornblende monzonite. Eastbound Interstate-80, east end of rest area, 1.04 mi west of Sussex County boundary; Tranquility 7.5-min quadrangle.

W291 - Hornblende monzonite. Ridge crest, east side Upper Pohatcong Mountain, $1.18 \mathrm{mi}$ northwest of intersection of New Jersey Routes 57 and 629; Washington 7.5-min quadrangle.

313-Hornblende monzonite. Oxford Mountain, northbound New Jersey Route 31, $500 \mathrm{ft}$ north of intersection with Tunnel Hill Road; Washington 7.5-min quadrangle.

6-Medium-coarse-grained hornblende alaskite. Lentine Aggregates Quarry, north of New Jersey Route 31, Glen Gardner; High Bridge 7.5-min quadrangle.

H10 - Foliated hornblende alaskite. West side of South Branch Raritan River, approximately $0.7 \mathrm{mi}$ southeast of Bunnvale; High Bridge 7.5-min quadrangle. 
Table 15. Major-oxide and trace-element concentrations and CIPW norms of Lake Hopatcong Intrusive Suite rocks, New Jersey Highlands.

[Analyses by X-ray fluorescence spectrometry except that $\mathrm{FeO}$ contents were determined by potentiometric titration (Jackson and others, 1987). Analyses by XRAL Activation Services, Ann Arbor, Mich., for all samples but two; analyses of samples P37 and 76 by U.S. Geological Survey, Reston, Va. NA, not analyzed. Sample localities are described following this table]

\begin{tabular}{|c|c|c|c|c|c|c|c|}
\hline & \multicolumn{7}{|c|}{ Pyroxene granite (Ypg) } \\
\hline & P37 & $\mathrm{H} 200$ & 264 & 49 & 506 & 537 & 539 \\
\hline \multicolumn{8}{|c|}{ Major oxides and loss on ignition (LOI), in weight percent } \\
\hline 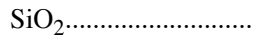 & 74.40 & 70.80 & 70.30 & 70.90 & 71.70 & 68.90 & 73.50 \\
\hline $\mathrm{TiO}_{2} \ldots \ldots \ldots \ldots \ldots \ldots \ldots \ldots$ & .29 & .49 & .55 & .42 & .42 & .37 & .40 \\
\hline $\mathrm{Al}_{2} \mathrm{O}_{3} \ldots \ldots \ldots \ldots \ldots \ldots \ldots$ & 12.60 & 14.30 & 12.70 & 13.20 & 12.20 & 14.10 & 12.20 \\
\hline 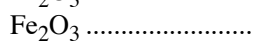 & 1.82 & 2.04 & 3.83 & .77 & 4.03 & 3.49 & 4.10 \\
\hline $\mathrm{FeO}$ & 1.00 & 1.30 & 1.60 & 2.30 & 1.70 & 1.30 & 1.30 \\
\hline $\mathrm{MgO}$ & .24 & .36 & .26 & .36 & .13 & .26 & .24 \\
\hline $\mathrm{CaO}$ & .89 & 1.39 & .81 & 1.99 & 1.01 & 1.27 & 1.69 \\
\hline $\mathrm{Na}_{2} \mathrm{O}$ & 4.42 & 5.56 & 3.89 & 3.81 & 3.19 & 4.65 & 4.58 \\
\hline $\mathrm{K}_{2} \mathrm{O}$ & 3.79 & 3.53 & 5.02 & 5.28 & 5.21 & 4.90 & 2.01 \\
\hline $\mathrm{P}_{2} \mathrm{O}_{5}$ & .05 & .08 & .08 & .09 & .04 & .06 & .06 \\
\hline $\mathrm{MnO}$ & .01 & .05 & .19 & .04 & .04 & .06 & .04 \\
\hline LOI............................... & .25 & .23 & .23 & .16 & .01 & .16 & .08 \\
\hline Total .......................... & 99.76 & 100.13 & 99.46 & 99.32 & 99.68 & 99.52 & 100.20 \\
\hline \multicolumn{8}{|c|}{ Trace elements, in parts per million } \\
\hline Ва ........................... & NA & 1,300 & 620 & 1,400 & 1,100 & 1,000 & 750 \\
\hline $\mathrm{Cr}$ & NA & 20 & 10 & $<10$ & 10 & $<10$ & 10 \\
\hline $\mathrm{Nb}$ & NA & 20 & 40 & 20 & 30 & 30 & 10 \\
\hline $\mathrm{Rb}$ & NA & 50 & 110 & 110 & 120 & 90 & 30 \\
\hline $\mathrm{Sr}$ & NA & 150 & 20 & 140 & 350 & 120 & 320 \\
\hline $\mathrm{Y}$ & NA & 30 & 150 & 50 & 40 & 100 & 20 \\
\hline $\mathrm{Zr}$ & NA & 750 & 1,100 & 440 & 1,100 & 840 & 750 \\
\hline \multicolumn{8}{|c|}{ CIPW norms, in weight percent } \\
\hline Qtz................................ & 32.22 & 22.25 & 26.81 & 23.92 & 31.21 & 20.76 & 35.61 \\
\hline 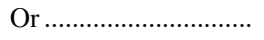 & 22.40 & 20.86 & 29.67 & 31.20 & 30.79 & 28.96 & 11.88 \\
\hline $\mathrm{Ab}$ & 37.40 & 47.05 & 32.92 & 32.24 & 26.99 & 39.35 & 38.76 \\
\hline An............................... & 3.35 & 3.64 & 2.37 & 3.32 & 3.58 & 3.13 & 6.80 \\
\hline С ................................ & - & - & - & - & - & - & - \\
\hline 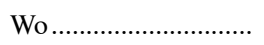 & - & .11 & - & - & .11 & .41 & - \\
\hline $\mathrm{Di}$ & .58 & 1.93 & .88 & 5.12 & .70 & 1.40 & .93 \\
\hline 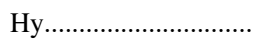 & .33 & - & .24 & 1.23 & - & - & .17 \\
\hline 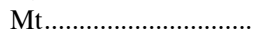 & 2.41 & 2.93 & 4.18 & 1.12 & 4.39 & 3.31 & 3.16 \\
\hline Il .............................. & .55 & .93 & 1.04 & .80 & .80 & .70 & .76 \\
\hline 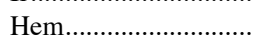 & .15 & .02 & .95 & - & 1.00 & 1.20 & 1.92 \\
\hline Аp. & .12 & .19 & .19 & .21 & .09 & .14 & .14 \\
\hline
\end{tabular}


Table 15. Major-oxide and trace-element concentrations and CIPW norms of Lake Hopatcong Intrusive Suite rocks, New Jersey Highlands-Continued.

\begin{tabular}{|c|c|c|c|c|c|c|}
\hline & \multicolumn{6}{|c|}{ Pyroxene granite $(\mathrm{Ypg})$-Continued } \\
\hline & W40 & $\mathrm{H} 1$ & D65 & 61 & W172 & 400 \\
\hline \multicolumn{7}{|c|}{ Major oxides and loss on ignition (LOI), in weight percent } \\
\hline $\mathrm{SiO}_{2} \ldots \ldots \ldots \ldots \ldots \ldots \ldots \ldots \ldots$ & 71.60 & 69.70 & 75.00 & 69.80 & 71.40 & 70.40 \\
\hline $\mathrm{TiO}_{2} \ldots \ldots \ldots \ldots \ldots \ldots \ldots \ldots$ & .37 & .46 & .28 & .48 & .60 & .44 \\
\hline $\mathrm{Al}_{2} \mathrm{O}_{3} \ldots \ldots \ldots \ldots \ldots \ldots \ldots \ldots$ & 12.40 & 13.80 & 11.30 & 12.70 & 11.90 & 12.30 \\
\hline $\mathrm{Fe}_{2} \mathrm{O}_{3} \ldots \ldots \ldots \ldots \ldots \ldots \ldots \ldots \ldots \ldots \ldots \ldots \ldots$ & 2.73 & 2.13 & .82 & 1.99 & 4.24 & 4.28 \\
\hline $\mathrm{FeO}$ & 1.80 & 1.55 & 1.10 & 1.90 & 2.10 & 2.00 \\
\hline $\mathrm{MgO}$ & .20 & .32 & .15 & .38 & .26 & .22 \\
\hline $\mathrm{CaO}$ & 1.32 & 1.35 & 1.50 & 2.97 & 1.80 & 1.48 \\
\hline $\mathrm{Na}_{2} \mathrm{O}$ & 4.68 & 4.75 & 2.79 & 2.96 & 4.58 & 4.00 \\
\hline $\mathrm{K}_{2} \mathrm{O}$ & 4.05 & 5.15 & 5.62 & 6.17 & 2.68 & 4.96 \\
\hline $\mathrm{P}_{2} \mathrm{O}_{5}$ & .04 & .10 & .02 & .07 & .12 & .06 \\
\hline $\mathrm{MnO}$ & .06 & .09 & .04 & .17 & .09 & .06 \\
\hline LOI & .31 & .16 & 1.08 & .47 & .47 & .10 \\
\hline Total........................... & 99.56 & 99.56 & 99.70 & 100.06 & 100.24 & 100.30 \\
\hline \multicolumn{7}{|c|}{ Trace elements, in parts per million } \\
\hline $\mathrm{Ba}$ & 610 & 790 & 1,000 & 720 & 380 & 490 \\
\hline $\mathrm{Cr}$ & 30 & 30 & 30 & 16 & $<10$ & 7,100 \\
\hline $\mathrm{Nb}$ & $<10$ & 20 & 70 & 50 & 40 & 60 \\
\hline $\mathrm{Rb}$ & 80 & 120 & 160 & 140 & 50 & 90 \\
\hline $\mathrm{Sr}$ & 90 & 90 & 80 & 130 & 80 & 40 \\
\hline Y & 70 & 80 & 140 & 170 & 100 & 130 \\
\hline $\mathrm{Zr}$ & 980 & 830 & 710 & 1,000 & 920 & 1,100 \\
\hline \multicolumn{7}{|c|}{ CIPW norms, in weight percent } \\
\hline 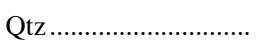 & 26.78 & 20.11 & 34.65 & 24.01 & 31.49 & 26.11 \\
\hline 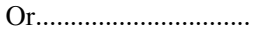 & 23.93 & 30.44 & 33.21 & 36.46 & 15.84 & 29.31 \\
\hline $\mathrm{Ab}$ & 39.60 & 40.19 & 23.61 & 25.05 & 38.76 & 33.85 \\
\hline 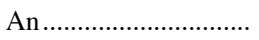 & .87 & 1.12 & 1.71 & 3.14 & 4.00 & .96 \\
\hline $\mathrm{C}$ & - & - & - & - & - & - \\
\hline 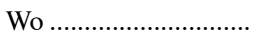 & 1.20 & .70 & 1.07 & 2.33 & .98 & 1.87 \\
\hline $\mathrm{Di}$ & 2.11 & 2.65 & 2.60 & 4.61 & 1.40 & 1.18 \\
\hline 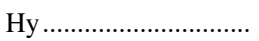 & - & - & - & - & - & - \\
\hline Mt .......................... & 3.96 & 3.09 & 1.19 & 2.89 & 5.32 & 5.37 \\
\hline 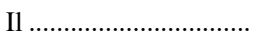 & .70 & .87 & .53 & .91 & 1.14 & .84 \\
\hline Hem .............................. & - & - & - & - & .57 & .58 \\
\hline Аp & .09 & .23 & .05 & .16 & .28 & .14 \\
\hline
\end{tabular}


Table 15. Major-oxide and trace-element concentrations and CIPW norms of Lake Hopatcong Intrusive Suite rocks, New Jersey Highlands - Continued.

\begin{tabular}{|c|c|c|c|c|c|c|c|c|}
\hline & \multicolumn{8}{|c|}{ Pyroxene granite $(\mathrm{Ypg})$ - Continued } \\
\hline & 228 & 127 & 226 & $\mathrm{C} 85$ & 440 & $\mathrm{~T} 29$ & 696 & 84 \\
\hline \multicolumn{9}{|c|}{ Major oxides and loss on ignition (LOI), in weight percent } \\
\hline $\mathrm{SiO}_{2} \ldots \ldots \ldots \ldots \ldots \ldots \ldots \ldots \ldots \ldots \ldots \ldots \ldots \ldots \ldots$ & 67.30 & 64.40 & 64.10 & 67.20 & 65.50 & 67.10 & 65.20 & 65.10 \\
\hline $\mathrm{TiO}_{2} \ldots \ldots \ldots \ldots \ldots \ldots \ldots \ldots$ & .64 & 1.03 & .81 & .49 & .60 & .42 & .52 & 1.14 \\
\hline $\mathrm{Al}_{2} \mathrm{O}_{3} \ldots \ldots \ldots \ldots \ldots \ldots \ldots$ & 13.20 & 12.80 & 14.60 & 14.10 & 14.30 & 14.50 & 14.70 & 13.60 \\
\hline $\mathrm{Fe}_{2} \mathrm{O}_{3} \ldots \ldots \ldots \ldots \ldots$ & 5.57 & 4.52 & 4.03 & 2.53 & 4.22 & 2.22 & 3.56 & 5.79 \\
\hline $\mathrm{FeO}$ & 2.50 & 3.40 & 3.90 & 2.50 & 2.60 & 1.70 & 2.20 & 3.20 \\
\hline $\mathrm{MgO}$ & .32 & .97 & .45 & .17 & .49 & .39 & .29 & .59 \\
\hline $\mathrm{CaO}$ & 1.90 & 2.74 & 1.73 & 1.33 & 2.40 & 1.34 & 2.24 & 1.79 \\
\hline $\mathrm{Na}_{2} \mathrm{O}$ & 4.62 & 3.84 & 5.04 & 4.72 & 4.65 & 3.67 & 3.76 & 5.95 \\
\hline $\mathrm{K}_{2} \mathrm{O}$ & 3.36 & 4.46 & 4.61 & 4.98 & 4.83 & 6.91 & 5.38 & 2.42 \\
\hline $\mathrm{P}_{2} \mathrm{O}_{5}$ & .08 & .31 & .18 & .07 & .11 & .05 & .06 & .31 \\
\hline $\mathrm{MnO}$ & .16 & .13 & .21 & .10 & .08 & .07 & .19 & .07 \\
\hline 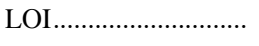 & .47 & .20 & .23 & .62 & .08 & .47 & .70 & .31 \\
\hline Total ......................... & 100.12 & 98.80 & 99.89 & 98.81 & 99.86 & 98.84 & 98.80 & 100.27 \\
\hline \multicolumn{9}{|c|}{ Trace elements, in parts per million } \\
\hline $\mathrm{Ba}$ & 940 & 950 & 1,700 & 1,200 & 1,000 & 1,200 & 590 & 480 \\
\hline $\mathrm{Cr}$ & 140 & 70 & 10 & $<10$ & $<10$ & 10 & 20 & 20 \\
\hline $\mathrm{Nb}$ & 60 & 20 & 50 & 40 & 30 & 30 & 30 & 100 \\
\hline $\mathrm{Rb}$ & 100 & 40 & 70 & 70 & 100 & 170 & 100 & 40 \\
\hline $\mathrm{Sr}$ & 110 & 150 & 80 & 80 & 150 & 180 & 100 & 60 \\
\hline $\mathrm{Y}$ & 160 & 110 & 110 & 90 & 50 & 20 & 90 & 200 \\
\hline $\mathrm{Zr}$ & 640 & 1,400 & 1,600 & 1,100 & 350 & 220 & 1,400 & 2,000 \\
\hline \multicolumn{9}{|c|}{ CIPW norms, in weight percent } \\
\hline 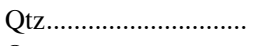 & 24.01 & 19.59 & 12.78 & 17.69 & 15.78 & 16.45 & 18.13 & 18.16 \\
\hline 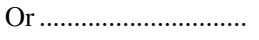 & 19.86 & 26.36 & 27.24 & 29.43 & 28.54 & 40.84 & 31.79 & 14.30 \\
\hline $\mathrm{Ab}$ & 39.09 & 32.49 & 42.65 & 39.94 & 39.35 & 31.05 & 31.82 & 50.35 \\
\hline 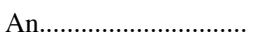 & 5.36 & 4.52 & 3.60 & 2.58 & 3.88 & 2.68 & 7.34 & 3.26 \\
\hline $\mathrm{C}$ & - & - & - & - & - & - & - & - \\
\hline 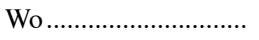 & .56 & - & - & - & 1.25 & - & .05 & - \\
\hline $\mathrm{Di}$ & 1.72 & 5.69 & 3.25 & 3.08 & 3.47 & 2.98 & 2.67 & 2.80 \\
\hline 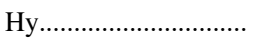 & - & .72 & 2.35 & .70 & - & .23 & - & .17 \\
\hline Mt................................. & 6.72 & 6.55 & 5.84 & 3.67 & 6.12 & 3.22 & 5.16 & 7.24 \\
\hline Il ................................ & 1.22 & 1.96 & 1.54 & .93 & 1.14 & .80 & .99 & 2.17 \\
\hline 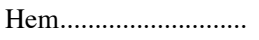 & .93 & - & - & - & - & - & - & .80 \\
\hline Ap & .19 & .72 & .42 & .16 & 25 & .12 & .14 & .72 \\
\hline
\end{tabular}


Table 15. Major-oxide and trace-element concentrations and CIPW norms of Lake Hopatcong Intrusive Suite rocks, New Jersey Highlands - Continued.

\begin{tabular}{|c|c|c|c|c|c|c|c|}
\hline & \multicolumn{3}{|c|}{ Pyroxene syenite (Yps) } & \multicolumn{4}{|c|}{ Pyroxene alaskite (Ypa) } \\
\hline & S42 & $\mathrm{T} 8$ & 317 & 76 & W5 & H393 & 2 \\
\hline \multicolumn{8}{|c|}{ Major oxides and loss on ignition (LOI), in weight percent } \\
\hline $\mathrm{SiO}_{2} \ldots \ldots \ldots \ldots \ldots \ldots \ldots \ldots \ldots$ & 61.30 & 59.00 & 63.90 & 68.60 & 69.00 & 70.40 & 71.40 \\
\hline $\mathrm{TiO}_{2} \ldots \ldots \ldots \ldots \ldots \ldots \ldots \ldots$ & .99 & .91 & .74 & .50 & .33 & .43 & .14 \\
\hline $\mathrm{Al}_{2} \mathrm{O}_{3} \ldots \ldots \ldots \ldots \ldots \ldots \ldots \ldots \ldots \ldots \ldots \ldots \ldots$ & 16.10 & 17.90 & 15.50 & 14.00 & 14.00 & 13.60 & 14.60 \\
\hline $\mathrm{Fe}_{2} \mathrm{O}_{3} \ldots \ldots \ldots \ldots \ldots \ldots \ldots \ldots \ldots \ldots \ldots$ & 5.10 & 4.02 & 2.85 & 3.81 & .60 & 2.28 & .32 \\
\hline $\mathrm{FeO}$ & 3.10 & 2.90 & 3.40 & 2.00 & 1.40 & 1.70 & 1.58 \\
\hline $\mathrm{MgO}$ & .77 & .79 & .53 & .32 & .70 & .24 & .36 \\
\hline $\mathrm{CaO}$ & 2.40 & 3.37 & 2.11 & .80 & 3.33 & 1.29 & 1.29 \\
\hline $\mathrm{Na}_{2} \mathrm{O} \ldots \ldots \ldots \ldots \ldots \ldots$ & 5.74 & 5.56 & 4.87 & 3.75 & 3.18 & 4.37 & 4.63 \\
\hline $\mathrm{K}_{2} \mathrm{O}$ & 4.37 & 4.84 & 5.58 & 5.31 & 5.94 & 5.05 & 5.49 \\
\hline $\mathrm{P}_{2} \mathrm{O}_{5}$ & .18 & .25 & .13 & .09 & .08 & .07 & .08 \\
\hline $\mathrm{MnO}$ & .13 & .19 & .12 & .05 & .05 & .10 & .09 \\
\hline LOI & .06 & .08 & .39 & .72 & 1.00 & .39 & .31 \\
\hline Total ......................... & 100.24 & 99.81 & 100.12 & 99.95 & 99.61 & 99.92 & 100.29 \\
\hline \multicolumn{8}{|c|}{ Trace elements, in parts per million } \\
\hline Ва ......................... & 1,300 & 2,400 & 2,100 & NA & 1,100 & 630 & 800 \\
\hline $\mathrm{Cr}$ & 10 & 16 & 13 & NA & 23 & 10 & 20 \\
\hline $\mathrm{Nb}$ & 20 & 20 & 40 & NA & 20 & $<10$ & $<10$ \\
\hline $\mathrm{Rb}$ & 50 & 70 & 100 & NA & 120 & 110 & 120 \\
\hline $\mathrm{Sr}$ & 180 & 420 & 130 & NA & 420 & 60 & 80 \\
\hline $\mathrm{Y}$ & 60 & 20 & 60 & NA & 50 & 30 & 50 \\
\hline $\mathrm{Zr}$ & 1,500 & 1,100 & 450 & NA & 170 & 830 & 710 \\
\hline \multicolumn{8}{|c|}{ CIPW norms, in weight percent } \\
\hline 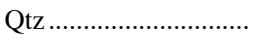 & 6.55 & 1.24 & 9.18 & 24.53 & 21.15 & 23.13 & 19.86 \\
\hline 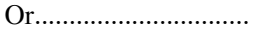 & 25.83 & 28.60 & 32.98 & 31.38 & 35.10 & 29.84 & 32.44 \\
\hline $\mathrm{Ab}$ & 48.57 & 47.05 & 41.21 & 31.73 & 26.91 & 36.98 & 39.18 \\
\hline 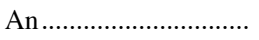 & 5.26 & 9.59 & 3.95 & 3.38 & 6.38 & 2.58 & 2.84 \\
\hline $\mathrm{C}$ & - & - & - & .84 & - & - & - \\
\hline 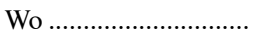 & - & - & - & - & .57 & .08 & - \\
\hline $\mathrm{Di}$ & 4.28 & 4.43 & 4.81 & - & 6.81 & 2.63 & 2.60 \\
\hline 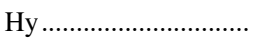 & .01 & .68 & 1.76 & .80 & - & - & 2.14 \\
\hline Mt .............................. & 7.39 & 5.83 & 4.13 & 5.16 & .87 & 3.31 & .46 \\
\hline Il .............................. & 1.88 & 1.73 & 1.41 & .95 & .63 & .82 & .27 \\
\hline 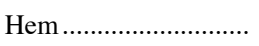 & - & - & - & .25 & - & - & - \\
\hline Ар & .42 & .58 & .30 & .21 & .19 & .16 & .19 \\
\hline
\end{tabular}




\section{Sample Descriptions and Collection Localities - Table 15}

P37-Medium-grained, foliated clinopyroxene granite. West side of ridge, east of West Lake, Fayson Lakes; Pompton Plains 7.5-min quadrangle.

H200-Clinopyroxene granite. South side of Electric Brook, 0.78 mi east of intersection of New Jersey Route 24 and East Springtown Road; Hackettstown 7.5-min quadrangle.

264-Clinopyroxene granite. Ridge crest, Upper Pohatcong Mountain, $0.70 \mathrm{mi}$ west of intersection of Erie Lackawanna Railroad tracks and New Jersey Route 629; Hackettstown 7.5-min quadrangle.

49-Hornblende-clinopyroxene granite. West side of small ridge, north of West Hanover Avenue, $250 \mathrm{ft}$ east of intersection of Shongum and North Ridge Roads; Mendham 7.5-min quadrangle.

506-Clinopyroxene granite. Southbound New Jersey Route 23, 0.33 mi north of north arm of Oak Ridge Reservoir; Newfoundland 7.5-min quadrangle.

537-Gneissic clinopyroxene granite to quartz monzonite. North side of bend in unimproved road, $1.05 \mathrm{mi}$ south of intersection of New Jersey Routes 605 and 607; Stanhope 7.5-min quadrangle.

539-Clinopyroxene granodiorite. East side of Lookout Mountain, west of Hudson Avenue, 0.39 mi north-northeast of intersection of New Jersey Route 607 and Lakeside Boulevard; Stanhope 7.5-min quadrangle.

W40-Clinopyroxene granite. South end of small ridge, north of New Jersey Route 638, 0.63 mi east of north end of Mastodon Lake; Wawayanda 7.5-min quadrangle.

H1 - Clinopyroxene granite. Lentine Aggregates Quarry, north of New Jersey Route 31, Glen Gardner; High Bridge 7.5-min quadrangle.

D65-Clinopyroxene granite. Mount Hope Quarry, north of Mount Hope Road, Rockaway; Dover 7.5-min quadrangle.

61 -Clinopyroxene granite. Ridge crest, north of golf course, 0.70 mi west-northwest of southwest end of Allamuchy Pond; Tranquility 7.5-min quadrangle.

W172-Clinopyroxene granodiorite. Southwest end of ridge crest, Point Mountain; Washington 7.5-min quadrangle.

400-Clinopyroxene granite. Hamburg Mountain, near crest of Vernon Valley Ski Resort, 0.74 mi southeast of intersection of New Jersey Route 94 and Sand Hill Road; Hamburg 7.5-min quadrangle.

228-Clinopyroxene quartz monzonite. Northwest side of County House Mountain, $0.65 \mathrm{mi}$ southwest of intersection of powerline and New Jersey Route 625; Washington 7.5-min quadrangle.

127-Clinopyroxene quartz syenite. Abandoned quarry, south of Gold Mine Road, 0.34 mi west of intersection with New Jersey Route 206; Stanhope 7.5-min quadrangle.

226-Clinopyroxene quartz monzonite. Schooleys Mountain, south of Wherli Road, $350 \mathrm{ft}$ west of intersection with West Springtown Road; Hackettstown 7.5-min quadrangle.

C85-Clinopyroxene quartz monzonite. East side of New Jersey Route 206, 0.28 mi north of intersection with Four Bridges Road; Chester 7.5-min quadrangle.

440 - Clinopyroxene quartz monzonite. East side of intersection of New Jersey Routes 607 and 609; Stanhope 7.5-min quadrangle.

T29-Clinopyroxene quartz syenite. Westbound Interstate-80, $0.45 \mathrm{mi}$ west of Sussex County boundary; Tranquility 7.5-min quadrangle.

696-Clinopyroxene quartz syenite. Byram Crushed Stone Quarry, east of New Jersey Route 206; Stanhope 7.5-min quadrangle.

84-Clinopyroxene quartz monzonite. Bowling Green Mountain, $270 \mathrm{ft}$ south of Weldon Road, 0.84 mi east of northernmost unnamed pond along Weldon Brook; Franklin 7.5-min quadrangle.

S42-Clinopyroxene monzonite. Westbound Interstate-80, $0.17 \mathrm{mi}$ east of Netcong Interchange; Stanhope 7.5-min quadrangle.

T8-Clinopyroxene monzonite. South side of ridge, $0.20 \mathrm{mi}$ north of intersection of Interstate-80 and New Jersey Route 604; Tranquility 7.5-min quadrangle.

317-Clinopyroxene syenite. South side of ridge crest, $0.43 \mathrm{mi}$ northwest of intersection of New Jersey Routes 638 and 515, 0.37 mi west of New Jersey Route 515, Wawayanda 7.5-min quadrangle.

76-Clinopyroxene alaskite. North side of Hickory Run Road, 0.22 mi northwest of intersection with New Jersey Route 513; Califon 7.5-min quadrangle.

W5-Clinopyroxene alaskite. North end of Wawayanda Lake, 200 $\mathrm{ft}$ northeast of intersection of Iron Mountain and Wawayanda Roads; Wawayanda 7.5-min quadrangle.

H393 - Clinopyroxene granite to alaskite. Lentine Aggregates Quarry, north of New Jersey Route 31, Glen Gardner; High Bridge 7.5-min quadrangle.

2-Clinopyroxene alaskite. Same location as sample 393; High Bridge 7.5-min quadrangle. 
Table 16. Major-oxide concentrations and CIPW norms of the Mount Eve Granite (Ygm), New Jersey Highlands.

[Analyses by X-ray fluorescence spectrometry except that $\mathrm{FeO}$ contents were determined by potentiometric titration (Jackson and others, 1987). Analyses by U.S. Geological Survey, Reston, Va. Sample localities are described below]

\begin{tabular}{|c|c|c|c|}
\hline & PI-1 & $\mathrm{U}-2$ & NE-3 \\
\hline \multicolumn{4}{|c|}{ Major oxides and loss on ignition (LOI), in weight percent } \\
\hline $\mathrm{SiO}_{2} \ldots \ldots \ldots \ldots \ldots \ldots \ldots \ldots$ & 66.90 & 71.40 & 73.10 \\
\hline $\mathrm{TiO}_{2} \ldots \ldots \ldots \ldots \ldots \ldots \ldots \ldots$ & .74 & .32 & .11 \\
\hline $\mathrm{Al}_{2} \mathrm{O}_{3} \ldots \ldots \ldots \ldots \ldots \ldots \ldots \ldots$ & 13.90 & 14.30 & 14.60 \\
\hline $\mathrm{Fe}_{2} \mathrm{O}_{3} \ldots \ldots \ldots \ldots \ldots \ldots \ldots \ldots$ & 1.60 & 1.71 & 1.40 \\
\hline $\mathrm{FeO}$ & 3.00 & .88 & .40 \\
\hline $\mathrm{MgO}$ & .74 & .31 & .16 \\
\hline $\mathrm{CaO}$ & 2.40 & .77 & 1.50 \\
\hline 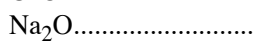 & 3.40 & 3.19 & 4.80 \\
\hline $\mathrm{K}_{2} \mathrm{O}$ & 5.30 & 5.80 & 3.00 \\
\hline $\mathrm{P}_{2} \mathrm{O}_{5} \ldots \ldots \ldots \ldots \ldots \ldots$ & .18 & .05 & .03 \\
\hline $\mathrm{MnO}$ & .10 & .02 & .02 \\
\hline LOI & .73 & .66 & .52 \\
\hline Total ....................... & 98.99 & 99.41 & 99.64 \\
\hline \multicolumn{4}{|c|}{ CIPW norms, in weight percent } \\
\hline Qtz ............................. & 20.90 & 29.00 & 31.10 \\
\hline 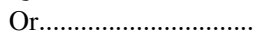 & 31.70 & 35.00 & 17.80 \\
\hline $\mathrm{Ab}$ & 29.30 & 27.20 & 40.40 \\
\hline 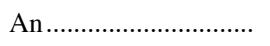 & 7.20 & 3.10 & 7.50 \\
\hline $\mathrm{C}$ & - & 1.60 & .80 \\
\hline $\mathrm{Di}$ & 3.30 & .80 & .40 \\
\hline 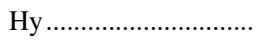 & 3.30 & - & - \\
\hline 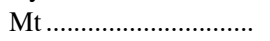 & 2.30 & 2.10 & 1.20 \\
\hline 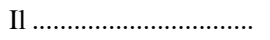 & 1.50 & .60 & .20 \\
\hline 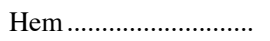 & - & .30 & .60 \\
\hline 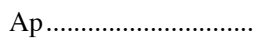 & .30 & .30 & - \\
\hline
\end{tabular}

\section{Sample Descriptions and Collection Localities-Table 16}

PI-1 - Hornblende-biotite granite from abandoned quarry in saddle between Mounts Adam and Eve, $200 \mathrm{ft}$ north of intersection of Little York and Hedges Roads; Pine Island 7.5-min quadrangle.

U-2 - Hornblende-biotite granite from northwest slope of Pochuck Mountain, about $200 \mathrm{ft}$ northeast of intersection of Liberty
Corners Road and unnamed northwest-trending road, $1 \mathrm{mi}$ southwest of Owens; Unionville 7.5-min quadrangle.

NE-3 - Hornblende granitoid from sharp bend in unnumbered road, about 1.4 mi S. $5^{\circ}$ W. from Sparta, N.J.; Newton East 7.5-min quadrangle. 
Table 17. Major-oxide and trace-element concentrations and CIPW norms of amphibolite (Ya), New Jersey Highlands.

[Analyses by X-ray fluorescence spectrometry except that FeO contents were determined by potentiometric titration (Jackson and others, 1987). Analyses by XRAL Activation Services, Ann Arbor, Mich. NA, not analyzed. Sample localities are described following this table]

\begin{tabular}{|c|c|c|c|c|c|c|c|c|}
\hline & 211 & 48 & 1044 & 271 & $423 \mathrm{~A}$ & B29 & 168 & 22 \\
\hline \multicolumn{9}{|c|}{ Major oxides and loss on ignition (LOI), in weight percent } \\
\hline 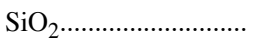 & 50.31 & 48.40 & 45.70 & 48.60 & 47.70 & 47.20 & 51.00 & 55.60 \\
\hline $\mathrm{TiO}_{2}$ & .84 & 1.53 & 1.22 & 1.40 & 1.66 & 2.00 & 1.50 & 1.01 \\
\hline $\mathrm{Al}_{2} \mathrm{O}_{3} \ldots \ldots \ldots \ldots \ldots \ldots \ldots \ldots$ & 15.03 & 15.80 & 13.90 & 13.80 & 18.40 & 15.00 & 15.20 & 12.70 \\
\hline $\mathrm{Fe}_{2} \mathrm{O}_{3} \ldots \ldots \ldots \ldots \ldots \ldots \ldots \ldots$ & 1.69 & 1.67 & 5.70 & 5.10 & 4.00 & 2.90 & 3.30 & 1.72 \\
\hline $\mathrm{FeO}$ & 8.62 & 8.53 & 8.50 & 7.80 & 7.50 & 9.60 & 7.20 & 6.35 \\
\hline $\mathrm{MgO}$ & 5.38 & 8.11 & 7.23 & 7.06 & 5.17 & 6.65 & 4.83 & .94 \\
\hline $\mathrm{CaO}$ & 12.31 & 11.00 & 9.95 & 10.30 & 9.22 & 8.96 & 8.46 & 6.49 \\
\hline $\mathrm{Na}_{2} \mathrm{O}$ & 3.03 & 3.12 & 2.96 & 3.45 & 3.59 & 3.79 & 4.64 & 6.78 \\
\hline $\mathrm{K}_{2} \mathrm{O}$ & .82 & .29 & .86 & 1.31 & 1.36 & .52 & 1.16 & .35 \\
\hline $\mathrm{P}_{2} \mathrm{O}_{5}$ & .14 & NA & .54 & .14 & .20 & .29 & .18 & 4.42 \\
\hline $\mathrm{MnO}$ & .20 & .17 & .35 & .13 & .17 & .20 & .14 & .15 \\
\hline LOI................................ & NA & $\mathrm{NA}$ & 1.16 & .54 & 1.31 & 1.31 & .62 & 3.00 \\
\hline 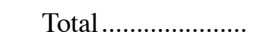 & 98.37 & 98.62 & 98.07 & 99.63 & 100.28 & 98.42 & 98.23 & 99.51 \\
\hline \multicolumn{9}{|c|}{ Trace elements, in parts per million } \\
\hline $\mathrm{Ba}$ & 145 & 195 & 230 & 90 & 270 & 250 & 340 & 820 \\
\hline $\mathrm{Cr}$ & NA & 231 & 120 & 242 & 39 & 260 & 180 & 20 \\
\hline $\mathrm{Cu}$ & 28 & 22 & NA & NA & NA & NA & NA & 4 \\
\hline $\mathrm{Nb}$ & NA & NA & 20 & 30 & 10 & 20 & 40 & $<10$ \\
\hline $\mathrm{Rb}$ & NA & 10 & 20 & 30 & 40 & 20 & 10 & 90 \\
\hline $\mathrm{Sc}$ & 42 & 27 & NA & NA & NA & NA & NA & 31 \\
\hline $\mathrm{Sr}$ & 323 & 487 & 530 & 100 & 390 & 320 & 380 & 580 \\
\hline $\mathrm{V}$ & 251 & 169 & NA & NA & NA & NA & NA & 100 \\
\hline 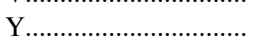 & NA & NA & 30 & 30 & 20 & 10 & 20 & 100 \\
\hline $\mathrm{Zr}$ & 116 & 85 & 90 & 100 & 120 & 130 & 110 & 1,000 \\
\hline \multicolumn{9}{|c|}{ CIPW norms, in weight percent } \\
\hline Qtz.............................. & - & - & - & - & - & - & - & 7.98 \\
\hline 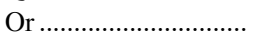 & 4.85 & 1.71 & 5.08 & 7.74 & 8.04 & 3.07 & 6.86 & 2.07 \\
\hline $\mathrm{Ab}$ & 25.64 & 25.57 & 25.05 & 25.25 & 26.63 & 30.33 & 37.10 & 57.37 \\
\hline 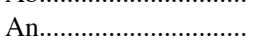 & 24.99 & 28.25 & 22.10 & 18.30 & 30.08 & 22.38 & 17.22 & 3.19 \\
\hline $\mathrm{Ne}$ & - & .45 & - & 2.14 & 2.03 & .94 & 1.17 & - \\
\hline 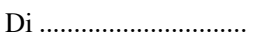 & 29.10 & 21.42 & 19.25 & 25.75 & 11.70 & 16.53 & 19.27 & .11 \\
\hline 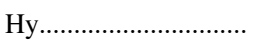 & 1.12 & - & 1.44 & - & - & - & - & 11.13 \\
\hline $\mathrm{Ol}$ & 8.31 & 15.89 & 12.16 & 9.53 & 11.08 & 15.18 & 7.94 & - \\
\hline Mt............................ & 2.45 & 2.42 & 8.26 & 7.39 & 5.80 & 4.20 & 4.78 & 2.49 \\
\hline 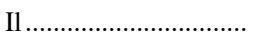 & 1.60 & 2.91 & 2.32 & 2.66 & 3.15 & 3.80 & 2.85 & 1.92 \\
\hline Ар & .32 & - & 1.25 & .32 & .46 & .67 & .42 & 10.24 \\
\hline
\end{tabular}




\section{Sample Descriptions and Collection Localities-Table 17}

211-Medium-grained, foliated hornblende-plagioclase amphibolite. Approximately $400 \mathrm{ft}$ north of Hollow Brook Road, 0.30 mi south of intersection of New Jersey Route 512 and Van Pelt Road; Gladstone 7.5-min quadrangle.

48-Medium-fine- to medium-grained, indistinctly foliated hornblende-plagioclase amphibolite. Pochuck Mountain, east side of New Jersey Route 565, 0.70 mi northeast of north end of Glenwood Lake; Hamburg 7.5-min quadrangle.

1044-Medium-grained, layered biotite-hornblende-plagioclase amphibolite. Interlayered with microcline gneiss. South side of New Jersey Route 616, 0.21 mi west of intersection with Sussex Mills Road; Newton East 7.5-min quadrangle.

271-Foliated biotite-hornblende-plagioclase amphibolite. Intercalated with layered biotite-quartz-plagioclase gneiss. Southbound Interstate-287, $0.44 \mathrm{mi}$ south-southwest of south end of Ramapo Lake; Wanaque 7.5-min quadrangle.

423 A - Porphyritic biotite-hornblende-plagioclase amphibolite. South side of swamp on Allamuchy Mountain, 0.87 mi south- east of northeast end of Tranquility Lake; Tranquility 7.5-min quadrangle.

B29-Medium-grained, weakly foliated hornblende-plagioclase amphibolite with $2 \mathrm{~mm}$ - to 4-mm-long hornblende in finer grained plagioclase matrix. Southwest end of ridge, north of Bear Swamp, 0.27 mi south of south end of large, unnamed pond on Shades of Death Road; Blairstown 7.5-min quadrangle.

168-Featureless clinopyroxene-hornblende-plagioclase amphibolite. North side of ridge, north of Upper Greenwood Lake, 0.59 mi northeast of intersection of Long House Drive and Lake Shore Drive; Greenwood Lake 7.5-min quadrangle.

22-Medium-fine-grained clinopyroxene-hornblende-plagioclase amphibolite. Approximately $350 \mathrm{ft}$ south of fork in unnamed stream south of Campbell Road, north end of Mine Mountain; Gladstone 7.5-min quadrangle. 
Table 18. Major-oxide and trace-element concentrations and CIPW norms of biotite-plagioclase gneiss (Ybp), New Jersey Highlands.

[The first three columns represent one type of biotite-plagioclase gneiss, and the fourth column represents another type. Analyses of samples 195, 223, and 1037 by X-ray fluorescence spectrometry except that $\mathrm{FeO}$ contents were determined by potentiometric titration (Jackson and others, 1987). Analyses of samples 195, 223, and 1037 by XRAL Activation Services, Ann Arbor, Mich. Sample localities for samples 195, 223, and 1037 are described following this table. Data for the metanorthosite are from Young and Icenhower (1989). NA, not analyzed]

\begin{tabular}{|c|c|c|c|c|}
\hline & 195 & 223 & 1037 & Metanorthosite* \\
\hline \multicolumn{5}{|c|}{ Major oxides and loss on ignition (LOI), in weight percent } \\
\hline $\mathrm{SiO}_{2} \ldots \ldots \ldots \ldots \ldots \ldots \ldots \ldots \ldots$ & 57.50 & 52.20 & 43.00 & 51.02 \\
\hline $\mathrm{TiO}_{2} \ldots \ldots \ldots \ldots \ldots \ldots \ldots \ldots$ & .74 & 1.45 & 1.70 & .68 \\
\hline $\mathrm{Al}_{2} \mathrm{O}_{3} \ldots \ldots \ldots \ldots \ldots \ldots \ldots$ & 13.90 & 14.30 & 15.20 & 25.78 \\
\hline $\mathrm{Fe}_{2} \mathrm{O}_{3}$ & 1.86 & 4.01 & 8.20 & .98 \\
\hline $\mathrm{FeO}$ & 6.90 & 7.50 & 9.70 & 2.82 \\
\hline 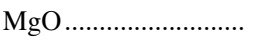 & 6.01 & 4.37 & 6.73 & 1.53 \\
\hline $\mathrm{CaO}$ & 7.37 & 7.82 & 8.99 & 8.68 \\
\hline $\mathrm{Na}_{2} \mathrm{O} \ldots \ldots \ldots \ldots \ldots \ldots \ldots \ldots$ & 2.75 & 2.57 & 2.24 & 4.31 \\
\hline 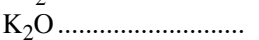 & 1.75 & 2.75 & 1.58 & 1.98 \\
\hline $\mathrm{P}_{2} \mathrm{O}_{5}$ & .18 & .20 & .04 & .09 \\
\hline $\mathrm{MnO}$ & .15 & .21 & .41 & .10 \\
\hline 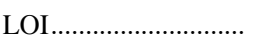 & .62 & 1.15 & .62 & 1.15 \\
\hline 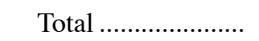 & 99.73 & 98.53 & 98.41 & 99.12 \\
\hline
\end{tabular}

Trace elements, in parts per million

\begin{tabular}{|c|c|c|c|c|}
\hline 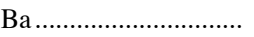 & 300 & 440 & 190 & 484 \\
\hline $\mathrm{Cr}$ & 440 & 80 & 20 & 48 \\
\hline Nb................................ & 10 & 20 & 20 & NA \\
\hline 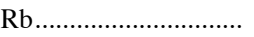 & 110 & 90 & 40 & 102 \\
\hline 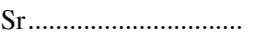 & 340 & 180 & 320 & 299 \\
\hline Y & 30 & 30 & $<10$ & NA \\
\hline $\mathrm{Zr}$ & $<10$ & 110 & $<10$ & 120 \\
\hline
\end{tabular}

CIPW norms, in weight percent

\begin{tabular}{|c|c|c|c|c|}
\hline Qtz............................... & 9.35 & 4.08 & - & - \\
\hline 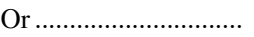 & 10.34 & 16.25 & 9.34 & - \\
\hline Ab................................ & 23.27 & 21.75 & 18.10 & - \\
\hline 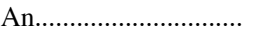 & 20.42 & 19.36 & 26.76 & - \\
\hline 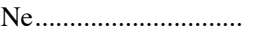 & - & - & .47 & - \\
\hline 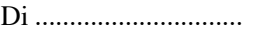 & 12.23 & 14.87 & 14.27 & - \\
\hline 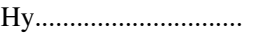 & 19.18 & 12.03 & - & - \\
\hline $\mathrm{Ol}$ & - & - & 13.67 & - \\
\hline Mt................................ & 2.70 & 5.81 & 11.89 & - \\
\hline 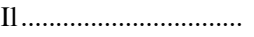 & 1.41 & 2.75 & 3.23 & - \\
\hline Ap & .42 & .46 & .09 & - \\
\hline
\end{tabular}

*Averaged data for five samples from the New Jersey Highlands; data from Young and Icenhower (1989). 


\section{Sample Descriptions and Collection Localities-Table 18}

195-Medium- to medium-coarse-grained clinopyroxene-biotiteplagioclase gneiss. Along Burnett Brook, $0.45 \mathrm{mi}$ north of intersection with Old Mill Road; Chester 7.5-min quadrangle.

223-Medium-fine-grained, well-layered hornblende-biotiteplagioclase gneiss. Terrace west of prominent north-trending ridge, $0.66 \mathrm{mi}$ west of southeast end of Glenwood Lake; Hamburg 7.5-min quadrangle.

1037-Foliated hornblende-biotite-plagioclase gneiss. West side of New Jersey Route 181, in bend, $0.73 \mathrm{mi}$ north of intersection with New Jersey Route 517; Newton East 7.5-min quadrangle. 
U.S. Department of the Interior

U.S. Geological Survey

\section{Geologic Studies in New Jersey and Eastern Pennsylvania}

\section{U.S. GEOLOGICAL SURVEY PROFESSIONAL PAPER 1565}

Prepared in cooperation with the

New Jersey Geological Survey

This volume was published as

separate chapters A-C 


\section{U.S. DEPARTMENT OF THE INTERIOR BRUCE BABBITT, Secretary}

U.S. GEOLOGICAL SURVEY

CHARLES G. GROAT, Director

Published in the Eastern Region, Reston, Va.

Any use of trade, product, or firm names in this publication is for descriptive purposes only and does not imply endorsement by the U.S. Government 


\section{VOLUME CONTENTS \\ [Letters designate the chapters]}

A. Late Proterozoic Diabase Dikes of the New Jersey HighlandsA Remnant of Iapetan Rifting in the North-Central Appalachians By Richard A. Volkert and John H. Puffer

B. Geology, Geochemistry, and Tectonostratigraphic Relations of the Crystalline Basement Beneath the Coastal Plain of New Jersey and Contiguous Areas

By Richard A. Volkert, Avery Ala Drake, Jr., and Peter J. Sugarman

C. Geochemistry and Stratigraphic Relations of Middle Proterozoic Rocks of the New Jersey Highlands

By Richard A. Volkert and Avery Ala Drake, Jr. 


\section{Selected Series of U.S. Geological Survey Publications}

\section{Books and Other Publications}

Professional Papers report scientific data and interpretations of lasting scientific interest that cover all facets of USGS investigations and research.

Bulletins contain significant data and interpretations that are of lasting scientific interest but are generally more limited in scope or geographic coverage than Professional Papers.

Water-Supply Papers are comprehensive reports that present significant interpretive results of hydrologic investigations of wide interest to professional geologists, hydrologists, and engineers. The series covers investigations in all phases of hydrology, including hydrogeology, availability of water, quality of water, and use of water.

Circulars are reports of programmatic or scientific information of an ephemeral nature; many present important scientific information of wide popular interest. Circulars are distributed at no cost to the public.

Fact Sheets communicate a wide variety of timely information on USGS programs, projects, and research. They commonly address issues of public interest. Fact Sheets generally are two or four pages long and are distributed at no cost to the public.

Reports in the Digital Data Series (DDS) distribute large amounts of data through digital media, including compact discread-only memory (CD-ROM). They are high-quality, interpretive publications designed as self-contained packages for viewing and interpreting data and typically contain data sets, software to view the data, and explanatory text.

Water-Resources Investigations Reports are papers of an interpretive nature made available to the public outside the formal USGS publications series. Copies are produced on request (unlike formal USGS publications) and are also available for public inspection at depositories indicated in USGS catalogs.

Open-File Reports can consist of basic data, preliminary reports, and a wide range of scientific documents on USGS investigations. Open-File Reports are designed for fast release and are available for public consultation at depositories.

\section{Maps}

Geologic Quadrangle Maps (GQ's) are multicolor geologic maps on topographic bases in 7.5- or 15-minute quadrangle formats (scales mainly 1:24,000 or 1:62,500) showing bedrock, surficial, or engineering geology. Maps generally include brief texts; some maps include structure and columnar sections only.

Geophysical Investigations Maps (GP's) are on topographic or planimetric bases at various scales. They show results of geophysical investigations using gravity, magnetic, seismic, or radioactivity surveys, which provide data on subsurface structures that are of economic or geologic significance.
Miscellaneous Investigations Series Maps or Geologic Investigations Series (I's) are on planimetric or topographic bases at various scales; they present a wide variety of format and subject matter. The series also incudes 7.5-minute quadrangle photogeologic maps on planimetric bases and planetary maps.

\section{Information Periodicals}

Metal Industry Indicators (MII's) is a free monthly newsletter that analyzes and forecasts the economic health of five metal industries with composite leading and coincident indexes: primary metals, steel, copper, primary and secondary aluminum, and aluminum mill products.

Mineral Industry Surveys (MIS's) are free periodic statistical and economic reports designed to provide timely statistical data on production, distribution, stocks, and consumption of significant mineral commodities. The surveys are issued monthly, quarterly, annually, or at other regular intervals, depending on the need for current data. The MIS's are published by commodity as well as by State. A series of international MIS's is also available.

Published on an annual basis, Mineral Commodity Summaries is the earliest Government publication to furnish estimates covering nonfuel mineral industry data. Data sheets contain information on the domestic industry structure, Government programs, tariffs, and 5-year salient statistics for more than 90 individual minerals and materials.

The Minerals Yearbook discusses the performance of the worldwide minerals and materials industry during a calendar year, and it provides background information to assist in interpreting that performance. The Minerals Yearbook consists of three volumes. Volume I, Metals and Minerals, contains chapters about virtually all metallic and industrial mineral commodities important to the U.S. economy. Volume II, Area Reports: Domestic, contains a chapter on the minerals industry of each of the 50 States and Puerto Rico and the Administered Islands. Volume III, Area Reports: International, is published as four separate reports. These reports collectively contain the latest available mineral data on more than 190 foreign countries and discuss the importance of minerals to the economies of these nations and the United States.

\section{Permanent Catalogs}

"Publications of the U.S. Geological Survey, 1879-1961" and "Publications of the U.S. Geological Survey, 19621970" are available in paperback book form and as a set of microfiche.

"Publications of the U.S. Geological Survey, 1971-1981" is available in paperback book form (two volumes, publications listing and index) and as a set of microfiche.

Annual supplements for 1982, 1983, 1984, 1985, 1986, and subsequent years are available in paperback book form. 


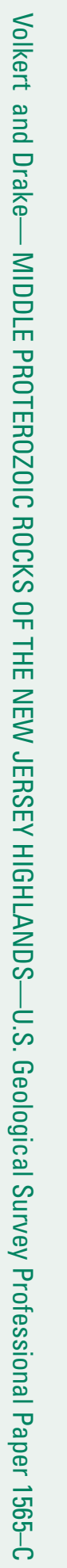

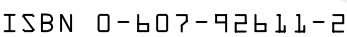

Printed on recycled paper

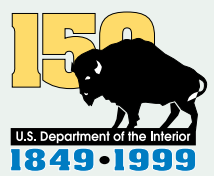

$\frac{1}{3}$ 